\title{
THE SALTASH TUCK-NET FISHERY AND THE ECOLOGY OF SOME ESTUARINE FISHES
}

\author{
By P. H. T. Hartley, B.Sc.
}

Assistant Naturalist to the Freshwater Biological Association: sometime Student Probationer at the Plymouth Laboratory

(Text-figs. I-I 7)

CONTENTS

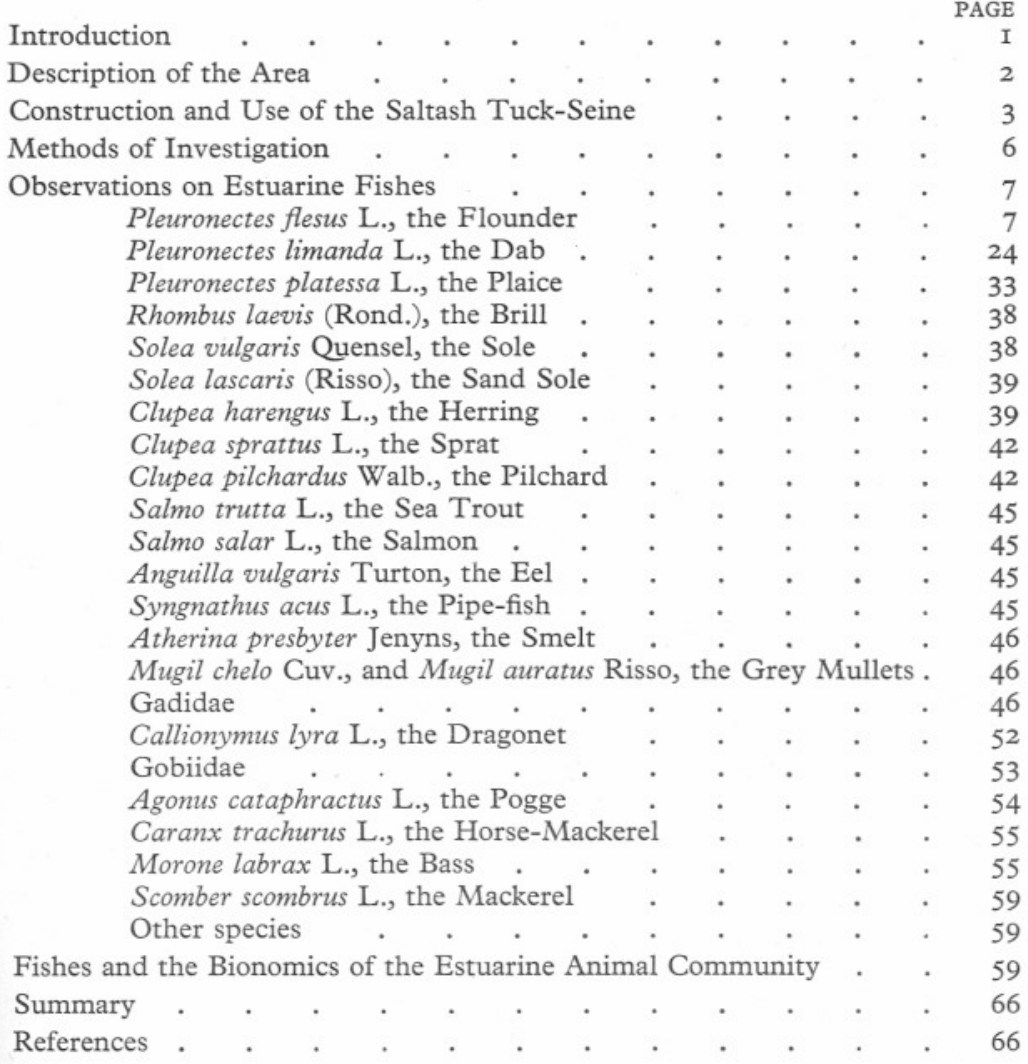

\section{INTRODUCTION}

The inshore fisherman is confined by the small size of his boat to fishing grounds of very limited extent. He cannot follow one species of fish in the course of its annual wanderings, but is compelled to await the movement of his quarry into his working area. He must shoot his nets or set his lines on the 
same grounds, month in and month out, catching those fish which happen to come within his reach. As a result he gains a detailed knowledge of the seasonal distribution of fishes on his grounds, and of their habits during their periods of abundance: but only with those fishes which never leave his area can he form a picture of the complete life history of any species.

The mud flats which border the estuaries of the rivers Tamar and Lynher are the working grounds of a winter seine-net fishery, carried on with open boats from villages along the shores. The net used is the "Saltash Tuck Seine", a modification of the ordinary shore seine for use on very soft mud. In November 1935, at the suggestion of Dr E. J. Allen, I began an investigation of this fishery and of the fishes of the estuaries. Some weeks were spent in learning to work with a tuck-net, and then, between January 1936 and December 1937, I made just under one hundred fishing expeditions to the rivers. The professional fishermen do not use the tuck-net in summer, for salmon are then a more profitable quarry than the flatfishes and bass of the estuaries; but in the investigation of the ecology of these fishes hauls were made in every month of the year. An ordinary commercial seine belonging to a Saltash fisherman was used on some occasions; on others a tuck-net fitted with a special cod-end of fine-meshed "French netting".

I should like to thank $\mathrm{Mr}$ E. Ford for much assistance in the preparation of this paper. It is also a pleasure to acknowledge my gratitude to $\mathrm{Mr} \mathrm{J}$. Gould, of Saltash. Without his exact knowledge of the Tamar and Lynher, his skilled working of a tuck-net, and his constant and generous cooperation, the investigation of the fishery could never have been made.

\section{Description OF THE AREA}

The rivers Tamar and Lynher flow into the western end of Plymouth Sound. The estuaries are bordered by mud flats, with occasional beaches of slaty shingle. In the lower half of the tidal area the mud flats are broad, and below low-water mark slope smoothly down to the bed of the river: it is on these slopes and on the shingle beaches that the tuck-net is fished. In the upper reaches the precipitous sides of the narrow mud banks make tucknetting impossible.

The mean tidal ranges at Devonport, Saltash and Cargreen are as follows:

\begin{tabular}{|c|c|c|c|c|}
\hline \multirow{5}{*}{$\begin{array}{l}\text { Devonport } \\
\text { Saltash }\end{array}$} & \multicolumn{2}{|c|}{ Spring tides } & \multicolumn{2}{|c|}{ Neap tides } \\
\hline & ft. & $\mathrm{m}$. & ft. & $\mathrm{m}$. \\
\hline & 15.5 & $4 \cdot 74$ & $12 \cdot 0$ & 3.67 \\
\hline & 150 & 4.58 & II $\cdot O$ & 3.27 \\
\hline & I4.75 & $4.5 \mathrm{I}$ & 10.75 & 3.29 \\
\hline
\end{tabular}

The so-called "eddy tide" runs close inshore in the opposite direction to the main tidal flow. This eddy current is usually only a few yards in width and makes no difference to the working of the net, though it is always used by the 
fishermen when travelling against the tide. On the West Muds ground, however, the reversal of the current is so extensive that the net must be fished in the direction of the eddy and not with the run of the tide.

The Tamar drains the western slopes of Dartmoor, the wettest area in the west of England (mean annual rainfall at Princetown: $8 \mathrm{I} \cdot 87 \mathrm{in} .=2079 \mathrm{~mm}$.). The Lynher rises in the Cornish moors where the precipitation is almost as great (mean annual rainfall at Altarnun: $59 \cdot 17$ in. $=1503 \mathrm{~mm}$.). Heavy rain is soon followed by a spate which, in winter, brings down masses of sodden leaves from the woods along the river valleys. These leaves are spread out on the mud banks on the inner sides of curves, and accumulate along the bottom of the river so thickly that it may be impossible to work a net where they lie. As a flood subsides it deposits a layer of fine, sticky mud called "slurry" on the flats, so that the surface level may be raised a few inches until the scouring of the next spring tides carries the deposit away to sea. A thick fall of "slurry" will sometimes so choke a net that it cannot be hauled into shallow water.

Fuller accounts of the estuaries of the Tamar and Lynher may be found in Percival (1929) and in Hartley \& Spooner (1938).

\section{Construction and Use of the Saltash Tuck Seine}

The principal difference of the tuck-net from an ordinary shore seine is in the belly of the net. From a seine which can be hauled ashore no fish can escape round or under the arms once the ends of the net are on land. With the Saltash net, fished on soft mud, this beaching is not possible, and the net (as will be explained later) must be lifted into a boat anchored in 2 or $3 \mathrm{ft}$. of water. From the broad, shallow belly of a shore seine escape during the lifting would be easy. A tuck-seine is therefore fitted with a funnel-shaped cod-end, some 3 fathoms long. The mouth of this "funnel" is square in section: the two sides are continuous with the arms of the net, the top is attached to a well-corked head rope. As the net is hauled, the mouth of the funnel stands widely open and the fish swim or are swept back into the long narrow cod-end, from which escape is difficult.

A typical Saltash tuck-seine has head and foot ropes 20 fathoms long. The arms are made of 18-ply cotton netting, 32 meshes to the yard, 60 meshes deep. The net is set on the ropes by the fourth-that is, the settings are placed three mesh lengths apart with four meshes between each setting. The bunt and cod-end are made from four funnel-shaped sections of I8-ply cotton netting, 42 meshes to the yard and 80 meshes deep at the wider end. The cod-end is at least $12 \mathrm{ft}$. $(3.65 \mathrm{~m}$.) long and is secured by a draw string. The net is preserved in a mixture of two to three parts of oil to one part of tar. At each end the head and foot ropes are spliced together into bridles. A $4 \mathrm{ft}$. pole, weighted at the lower end, is secured across each bridle by clove-hitches in the bridle ropes. To each bridle is attached a I-in. grass warp, 30 fathoms long, marked off into Io-fathom lengths by pieces of leather. 
A Saltash tuck seine is fished from an open boat, I2-I6 ft. long, with a crew of two. Work begins about $\mathrm{I} \frac{1}{2} \mathrm{hr}$. before low water. By that time it will be possible to work along the edges of the mud flats and shoot the net in the deep water on their slopes. The speed of the tidal stream, too, will have begun to grow less: except during the slackest neaps the current at half-tide is strong enough to lift one arm of the net and roll it round the other. The free end of one warp is made fast in the boat; this warp is referred to as the "boat warp", and the pole across the bridle to which it is made fast as the "boat pole". The warp and pole at the other end of the net are the "shore warp" and "shore

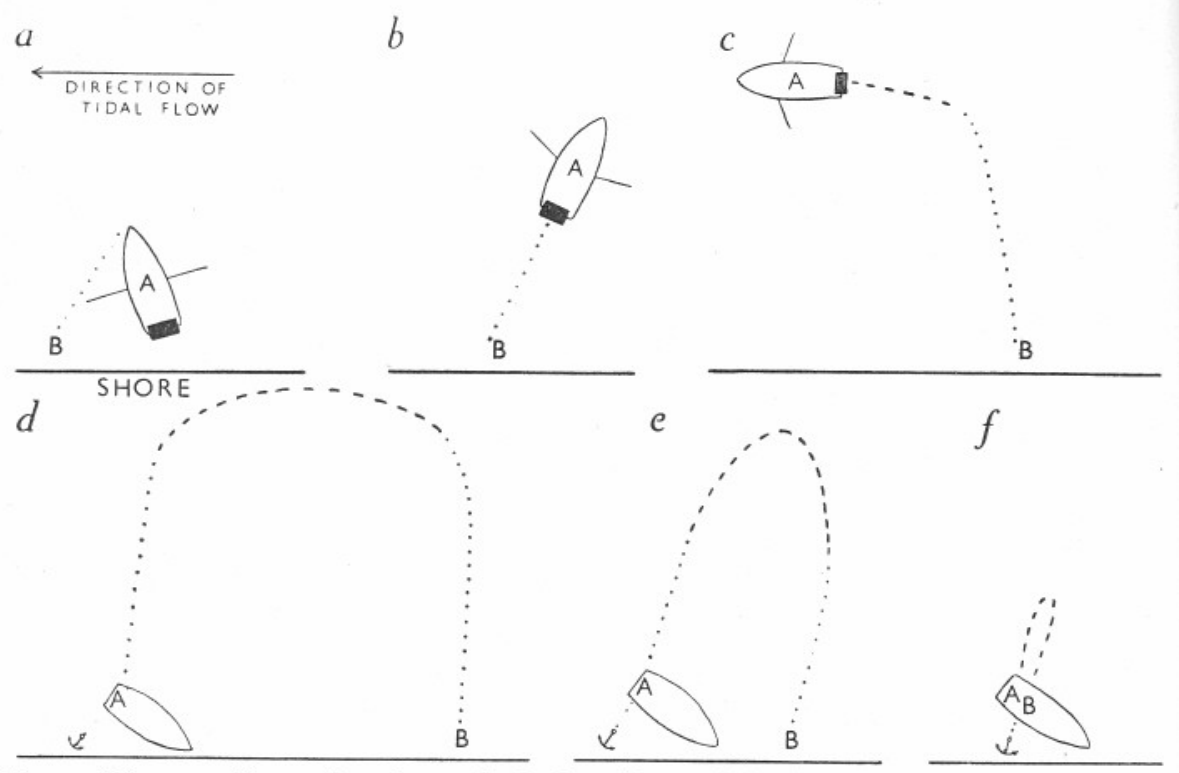

Fig. I. Diagrams illustrating the method of working a Saltash tuck-seine; the net is represented by a broken line, and the warps by dotted lines. In figures $a, b$ and $c$ the net is piled on the stern of the boat, and is represented by a solid rectangle.

pole". The boat warp is heaped in the stern of the boat and the boat pole laid across it. The upper end of the boat pole projects over the quarter, pointing against the current as the boat lies stern to the beach. The net is piled on the transom, the cod-end being looped over the projecting end of the boat pole. The shore pole is laid on the top of the net and the shore warp carried forward along the side of the boat, outside a thole-pin and into the bows. The shore warp is heaped (not coiled) in the bows, the free end on top.

The net is now ready for shooting. One man, $B$, leaves the boat and stands in the shallows holding the free end of the shore warp (Fig. I $a$ ). The second man, $A$, rows the boat out from the shore, heading up into the tide (I $b$ ). The shore warp pays out from the bows of the boat round the thole pin, tightens and pulls the shore pole overboard. $A$ turns the boat parallel with the shore 
and rows with the tide as the net shoots itself over the stern of the boat (I $c$ ). As soon as the boat pole is pulled overboard $A$ turns the boat for the shore, rows inward as the boat warp pays out over the stern and anchors in the shallows some $25-50$ yards below $B$ (I $d$ ). The anchor is made fast to a thole pin near the stern. $A$ and $B$ haul on their warps until $B$ has Io fathoms of warp in the water: he then moves nearer the boat and hauling is continued until the tops of the poles break the surface (I $e$ ). $B$ then wades to the boat dragging his end of the net with him; he climbs into the boat and goes aft to stand by $A$ (I $f)$ : the two men then haul the net into the boat as rapidly as possible. In a good haul a few fish are usually found tangled up in the arms of the net, but the bulk of the catch will be in the cod-end. It takes IO-I 5 min. to make one shot. *

$A$ is usually the senior man; he decides how much to "head" the net into the tide. If the tide be running strongly he will shoot the net as far above $B$ as he can: at slack water he will row straight offshore. Occasionally, at neap tides, a "keg-haul" is made over a submerged flat. The shore warp is made fast to an anchored buoy, and picked up after the net has been shot. Both warps are hauled into the boat. A "keg-haul" rarely yields a big catch, for the net sweeps a smaller area than is covered when a shot is made from the shore. Work continues until about one hour's flood. The rising of the tide is always felt first along the bottom of the river; a net may be rolled up by the speed of the current on the river bed, while sticks floating on the surface are scarcely moving upstream.

The number of fishermen working regularly in the estuaries has decreased and is still decreasing. The younger men willingly leave the river if they can find regular employment ashore, and the older hands all say that the fishing is finished. This is not a comparison with "good old days" remembered by occasional large catches, but a statement of fact. For example, in days gone by some of the Saltash men made a living all the year round by catching "smelts" (Atherina presbyter). Now this fish has become so rare that its capture excites comment: I have myself seen only nine specimens in two years' work.

The fisherman's year used to open with the oyster dredging in the Tamar: now the oyster beds are worked out. From March till August is the salmon season, when tuck-nets are put away, and the men live in house-boats in the upper reaches of the estuary, working their Ioo-fathom seines. It is to the salmon that the fishermen look for their living. A year with a small run of grilse, such as that of 1937 (Menzies, I938), is a serious matter, for it may mean two bad seasons in succession-the poor 1938 season showed this only too well. In midsummer some prawns are caught in hand-nets. In the early autumn comes the herring season when light drift-nets are set at dawn and dusk. In recent years this fishery has failed within the rivers as it has in the sea outside. The small shoals of herring which did appear in the harbour in I937 arrived in mid-October, though they had been expected a month earlier.

* Davis (I937) has pointed out that the tuck-seine closely resembles a trawl in its action. 
After the herring comes the tuck-netting season. Catches in the last few years have been so small that day after day it may not be worth while to take the fish to market. Even if a large catch be made, the estuarine fisherman will only get a good price for it if heavy weather has prevented the steam trawlers from working.

The local men attribute the decline in the fisheries to various causes-the activities of prawn trawlers in the harbour, the depredations of cormorants (Phalacrocorax carbo carbo) and the silting up of channels. It seems probable that the true main cause is the general disastrous decline in fish stocks which has been observed in the western end of the English Channel since 1932 (Russell, 1938).

For some years the sale of mussels (Mytilus edulis) from the rivers has been illegal. In December 1937 the local medical authorities banned the sale of all shellifish whatsoever from the Tamar and its tributaries, so that another possible source of income-gathering cockles (Cardium edule) —was lost to the fishermen. At one time several punt guns were regularly used in the winter, but professional punting is now practically extinct, although some widgeon (Anas penelope penelope) still come to the estuaries.

When the results of the fishing expeditions were summarized, it soon became obvious that the factors which limit the inshore fisherman in his work were also limitations upon the scientific results of the investigation. It was possible to study the changes in the composition of the estuarine fish community in detail, but the irregularity of occurrence of some fish made it very difficult to work out the changes taking place in the lives of individual species. The only estuarine species studied out of its estuarine environment was the flounder; all other fishes were studied only as they happened to appear on the fishing grounds, with the inevitable result that conclusions on the bionomics of many of them can only be put forward as a series of tentative suggestions.

\section{Methods OF Investigation}

All fish, with the exception of clupeoids, were measured from the tip of the snout to the end of the longest caudal ray. The young clupeoids living in the estuaries of the Plymouth area often have the caudal fin considerably abraded or broken (Ford, I928): some fish have no caudal rays at all. Clupeoids were, therefore, measured to the end of the scaled area of the caudal peduncle. Arithmetic mean lengths were calculated by dividing the fish into length groups measured to the nearest whole centimetre below, and by multiplying the divergences from the modal length by the number of fish showing each divergence, and dividing the difference between the total divergences above and below the mode by the number of fish examined. $0.5 \mathrm{~cm}$. was added to the length so calculated in order to give the centre of the group.

Flounders were weighed to the nearest I g. below. 
In the three species of pleuronectids some otolith readings were made. The narrow, opaque, white rings in the otoliths are called "winter rings", the broader, translucent zones dividing them "summer zones". That this nomenclature is justified is shown in the following table, in which the percentage of otoliths having a winter ring on the outer edge is shown for each month of autumn and winter, I937.

\begin{tabular}{ccccc}
\multicolumn{2}{c}{ Month } & $\begin{array}{c}\text { Pleuronectes } \\
\text { flesus }\end{array}$ & $\begin{array}{c}\text { Pleuronectes } \\
\text { limanda }\end{array}$ & $\begin{array}{c}\text { Pleuronectes } \\
\text { platessa }\end{array}$ \\
I937 Sept. &. & 4 &. \\
& Oct. & I6 & 7 & 27 \\
Nov. & 49 & 5 & I8 \\
Dec. & 70 & 37 & 59 \\
I938 Jan. & 93 &.. &.. \\
& Feb. & 84 &.. &..
\end{tabular}

In each species there is a marked increase in the percentage of fish showing an opaque "winter ring" as the winter fasting period comes on.

In the study of feeding habits the food organisms bave been summarized on a basis of occurrence. This has been preferred to the apparently greater accuracy of numbers for two reasons:

(i) The food organisms vary considerably in size; one large shrimp obviously contains more nourishment than several mysids.

(ii) A large number of an unusual food organism in one fish would give quite undue prominence to that organism in a numerical summary.

A displacement method of assessment would perhaps be ideal, but it would be too cumbrous for use with large samples of fish.

In most species only the contents of the stomach were examined, but in the pleuronectids it was found that animal remains in the intestine were usually recognizable, being less comminuted than in other fishes. I felt it to be better, therefore, when dealing with flounders, dabs and plaice, to count the occurrence of food organisms in stomach and intestine separately, so that due prominence should be given to the commoner animals.

\section{OBSERVATIONS ON ESTUARINE Fishes}

\section{Pleuronectes flesus L., the Flounder}

The flounder is caught in the tuck-nets from October until March, and is, with the bass (Morone labrax), the most valuable quarry of the netsmen. Very little work has been done upon this species in Great Britain; but in the Elbe and the Baltic it is the objective of important fisheries, and several investigations of its bionomics have been made. In the Tamar and Lynher the flounder is the estuarine fish par excellence: and on account of this, and the small knowledge of its life history in this country, it was made the special object of the investigation of the ecology of the fishes of the estuaries. The bionomics of all the fishes taken in the tuck-net were investigated as fully as 
possible, but, to some extent, all other species were regarded as forming part of the animate environment of the flounder.

Several species of flatfish enter the estuaries of the Tamar and Lynher, but the flounder is the only one of these to colonize the brackish upper reaches where salt and fresh waters mingle. The flounder has considerable powers of osmotic regulation. Von Buddenbrock (1936) found that the species had three mechanisms for maintaining the osmotic pressure of the blood when living in water of low salinity-a remarkable impermeability of the skin, a complete cessation of imbibition, and an increased secretion of urine. Flounders are numerous in the upper parts of the estuaries, where there are great salinity changes in a comparatively short time, and some of the younger fish ascend into fresh water where they "dwell and thrive to a hand's breadth and almost twice so long" (Walton, I659). In the Tavy, a typical, acid, westcountry trout stream, the flounders may be seen moving about among the brown trout (Salmo trutta). In the summer months flounders of all sizes are rare on most of the fishing grounds. According to the local fishermen, they wander away up the gutters which drain the saltings and creeks on either side of the rivers: and there some are certainly caught in stop-nets at low tide. Results of marking experiments begun in the autumn of 1937 suggest that there is also a spring movement of immature flounders up the main channels of the rivers, into regions where the salinities are lower than those of the winter haunts.

\section{Growth and Age.}

Several authors have emphasized the variability of the growth rate in the flounder. Cunningham (I896) found that a number of young flounders, kept in the laboratory at Plymouth and "regularly but not very liberally fed", grew from a length of $\mathrm{I} .25 \mathrm{~cm}$. in May I890, to lengths varying between 5.0 and $19.0 \mathrm{~cm}$. in May I891. Blegvad (1932) showed a correlation between the growth rate of O-group flounders and the temperature of the sea, the length of the fish increasing with an increase of temperature; he found, too, that growth is comparatively small in areas where young fish assemble in large numbers. Lübbert and Ehrenbaum (1936) also observed that the rate of growth varied with the density of the population.

Flounders less than $7 \mathrm{~cm}$. in length were never taken in the tuck-net. This was not due to the escape of the smallest fishes through the meshes of the net, for many plaice and dabs of 3 and $4 \mathrm{~cm}$. were caught during the summer months. There are three possible explanations of the absence of small flounders from the tuck-net catches:

(i) That the young fish do not enter the estuaries until nearly a year old.

(ii) That the young fish usually haunt grounds where the tuck-net cannot be worked.

(iii) That the young fish have a pelagic habit and so avoid capture in a net which sweeps along the river bottom. 
It is improbable that the first explanation is the true one, for Mr E. Ford tells me that he took some very small flounders in the Tamar and Lynher in a fine-meshed net used for the capture of young herring. The true reason is
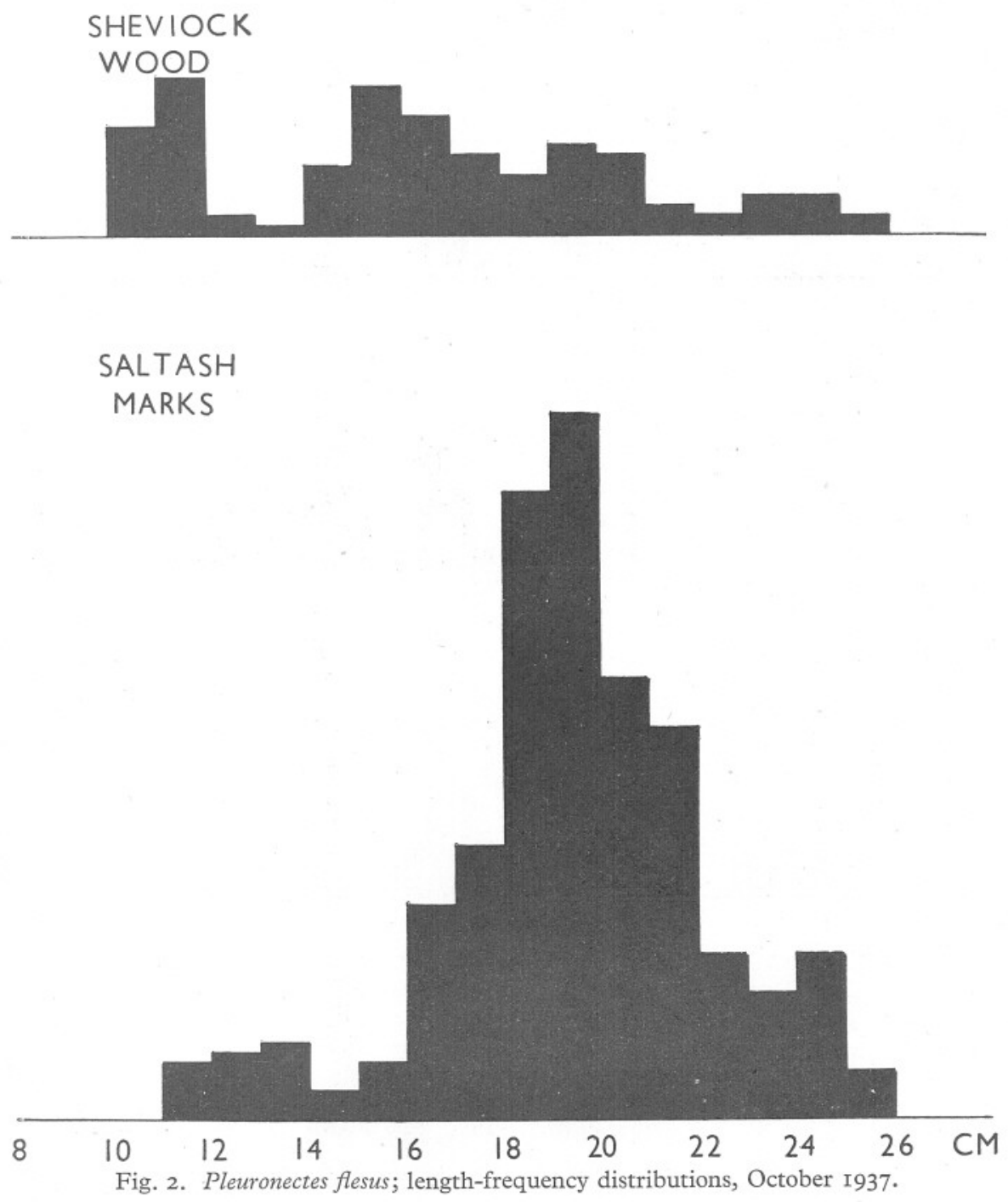

probably in the second or third suggestion, or in a combination of them. Be the cause what it may, O-group flounders were almost completely lacking in the material available for the study of growth.

There were two other sources of difficulty in the adequate sampling of the flounder population: 
(i) During the summer months it was difficult to catch any flounders at all. Only on the Sheviock Wood ground were flounders numerous during the hot weather; and it proved to be impossible to arrange regular summer work

1936

1937
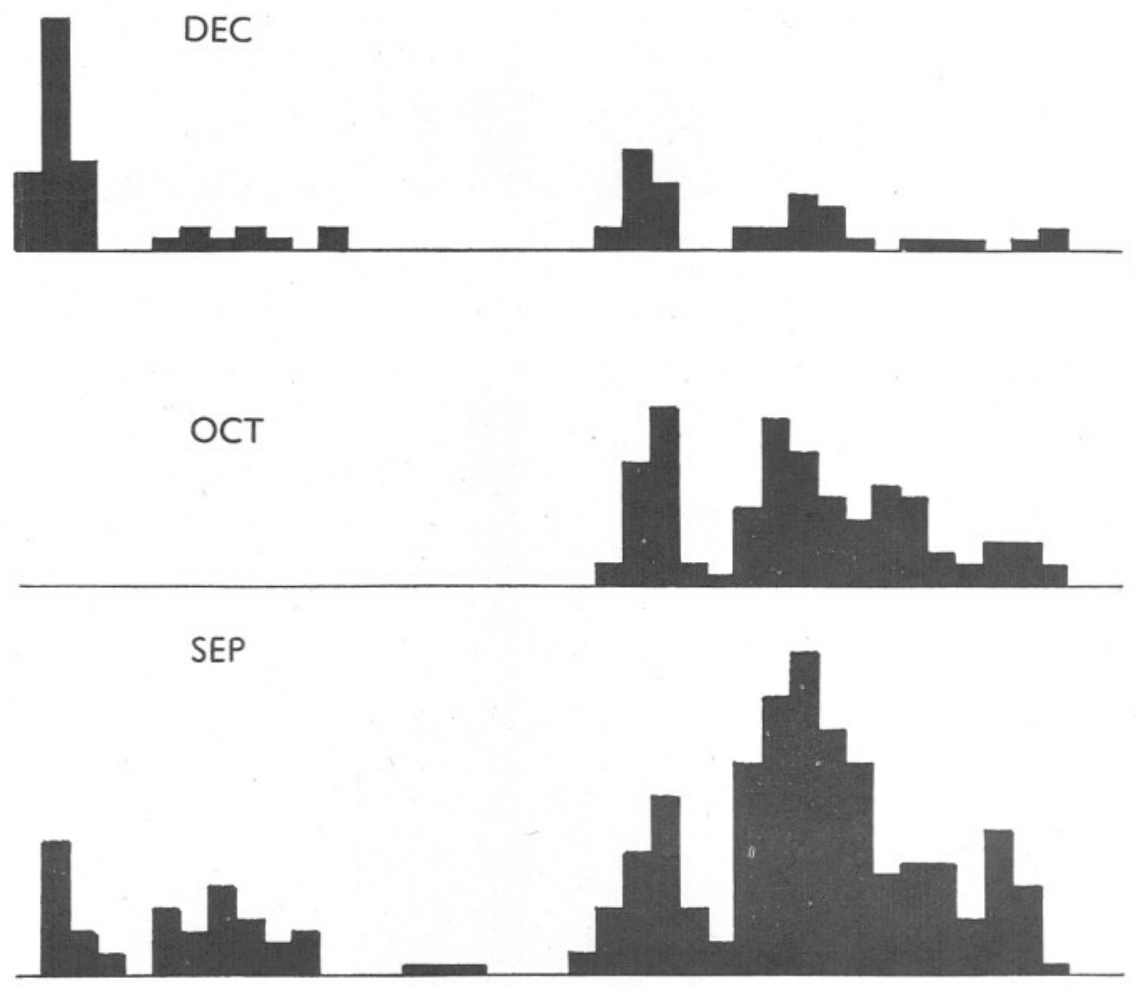

JUL

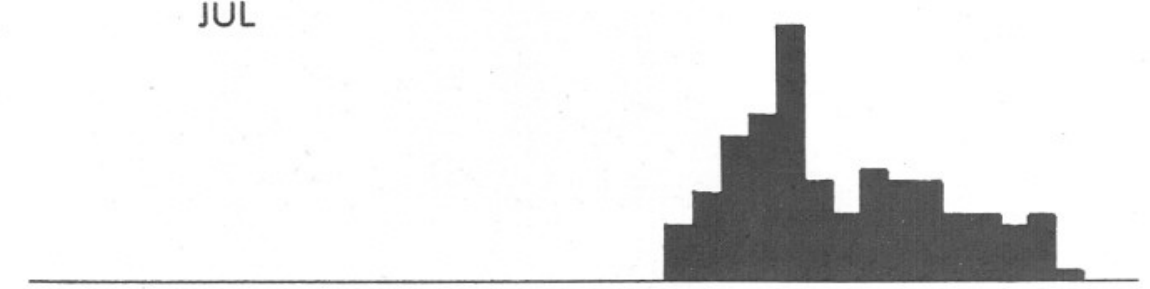

$\begin{array}{llllllllllllllllllllll}8 & 10 & 12 & 14 & 16 & 18 & 20 & 22 & 24 & 26 & 8 & 10 & 12 & 14 & 16 & 18 & 20 & 22 & 24 & 26 & \mathrm{CM}\end{array}$

Fig. 3. Pleuronectes flesus; length-frequency distributions, Sheviock Wood Grounds.

there. A $16 \mathrm{ft}$. tide was needed to work at Sheviock, and the local fishermen, being much occupied with their salmon-nets, were rarely available for work with the tuck-net. 
(ii) The distribution of the fish was not uniform throughout the estuaries at any one time (Fig. 2) and the distribution of fish on one ground changed in the course of the year (Fig. 3). On the Saltash "marks", where the majority of the flounders were obtained, the smaller length groups were not strongly represented.

Histograms were prepared to show the length-frequency distribution of the flounders in each month of 1936 and I937. It was found that only one modal peak consistently emerged-that of the I-group fish (Figs. 2-5). Other modes were rarely well marked so that at best the monthly histograms only suggested the possible lengths of the older year-groups. Between I4 and $24 \mathrm{~cm}$. a single peak may sometimes emerge but it will be shown later that this contains at least two and perhaps three modes. Above the length of $24 \mathrm{~cm}$. fish are not present in sufficient numbers to permit the deduction of year-groupings.
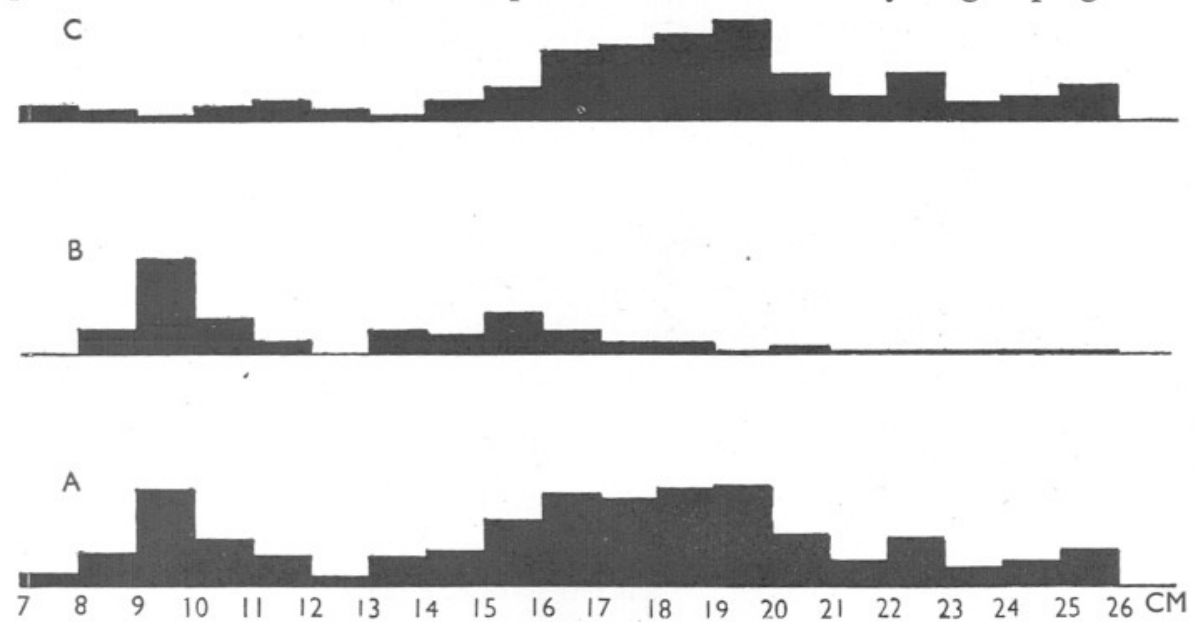

Fig. 4. Pleuronectes flesus; length-frequency distributions, September-December 1936

Marking experiments carried out in the autumn of 1937 showed that the Tamar flounders do not grow during the last third of the year: the lengthfrequency distributions for the months September, October, November and December may, therefore, be lumped together (Figs. 4, 5) in order to increase the absolute numbers of fish in one histogram. In Fig. $5 a$ "Total Fish for Autumn I937", the modal peak of the I-group stands out clearly at approximately $\mathrm{II} \cdot 5 \mathrm{~cm}$. Above $14 \mathrm{~cm}$. it would be unwise to attempt to define the position of any mode. In Fig. 5 b, on the other hand, "Sheviock Wood" only, there is the indication of a second modal peak at about $16 \mathrm{~cm}$.: it is suggested that this mode represents the II-group. In the histogram for Saltash only (Fig. 5 c) this II-group mode is missing, but a modal peak is found at approximately $19 \mathrm{~cm}$. Movements of marked fish exclude the possibility that there are separate populations on the two fishing grounds, growing at different speeds. It is, therefore, not unreasonable to suggest that this $19 \mathrm{~cm}$. mode 
represents the III-group fish. Fig. 4, "Autumn, 1936", is similar to Fig. 5, though for a smaller number of fish. The I-group stands out clearly, though the flounders are nearly $2 \mathrm{~cm}$. smaller than in I937. The II-group is marked at Sheviock, the III-group at Saltash.
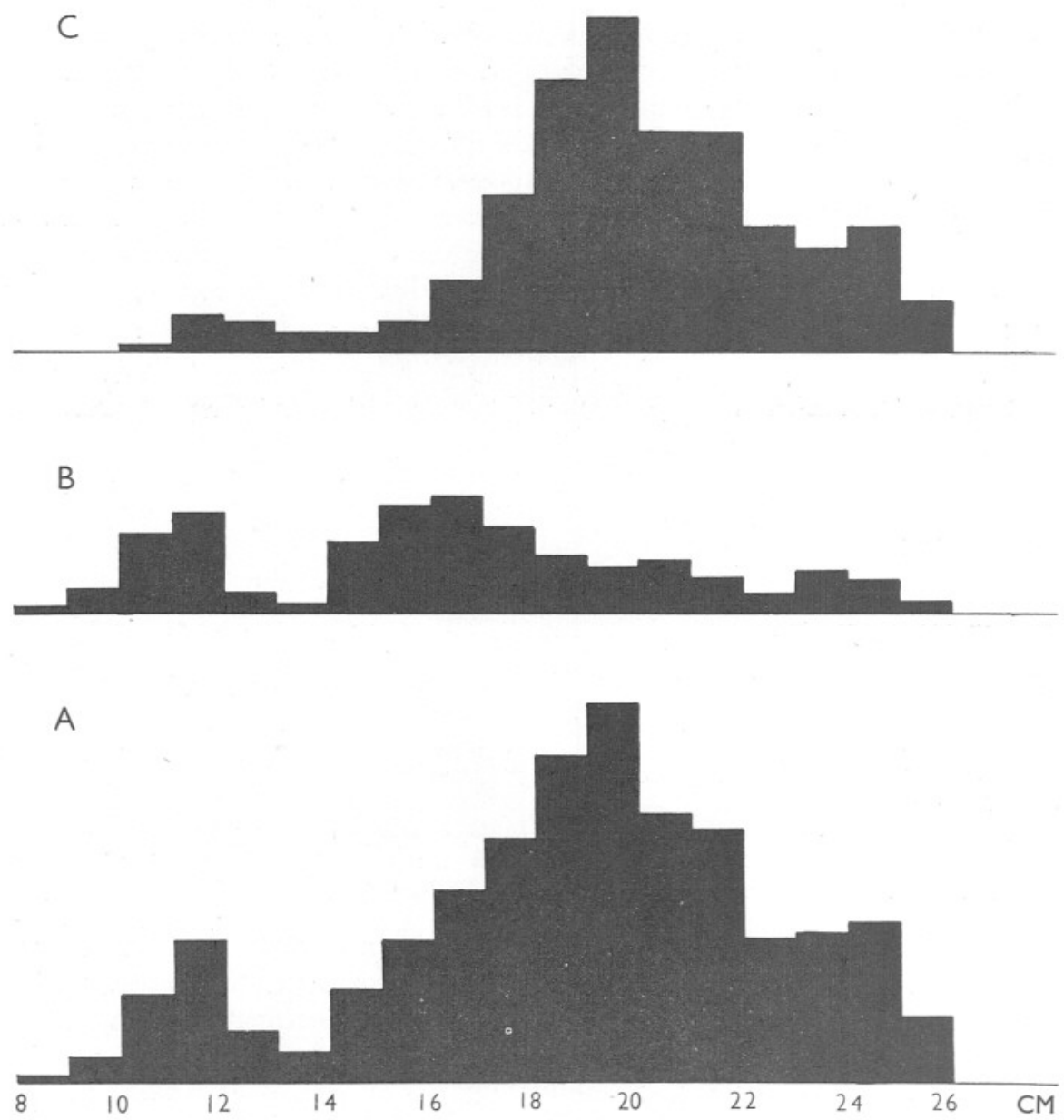

Fig. 5. Pleuronectes flesus; length-frequency distributions, September-December 1937.

From Figs. 4 and 5 it is impossible to tell the size or number of the yeargroups above III. From the length-frequency histogram for April 1936 and April 1937 (Fig. 6) it may be suggested that those fish of the IV-group which still remain in the river are between 20 and $2 \mathrm{I} \mathrm{cm}$. in length. It must be admitted that no other monthly histogram shows this so clearly though some of them hint at it.

From the evidence of Figs. 4 and 5, coupled with such supplementary 
information as may be obtained from the monthly histograms, the following view of the year-grouping of the Tamar flounders is tentatively put forward:

\section{Autumn. Period of No Growth}

\begin{tabular}{|c|c|c|c|}
\hline Year-group & $\begin{array}{l}\text { Age } \\
\text { years }\end{array}$ & $\begin{array}{c}\text { Length, I936 } \\
\mathrm{cm} .\end{array}$ & $\begin{array}{c}\text { Length, I937 } \\
\mathrm{cm} .\end{array}$ \\
\hline 0 & $\frac{1}{2}$ & .. & \\
\hline & $\mathrm{I} \frac{1}{2}$ & $9 \cdot 5$ & II. 5 \\
\hline II & $2 \frac{1}{2}$ & $15 \cdot 5$ & $16 \cdot 0$ \\
\hline III & $3 \frac{1}{2}$ & (I9.0) & 19.5 \\
\hline
\end{tabular}

These figures are comparable with year-groupings of flounders on the southern coasts of Sweden (Molander, I932):

\begin{tabular}{|c|c|c|c|c|c|}
\hline \multirow{4}{*}{ Year-group } & \multirow{2}{*}{\multicolumn{2}{|c|}{$\begin{array}{l}\text { Plymouth } \\
\text { Autumn }\end{array}$}} & \multicolumn{3}{|c|}{ Ystad, Sweden } \\
\hline & & & \multirow{3}{*}{$\begin{array}{l}\text { Sept. } \\
\text { I } 929 \\
\mathrm{~cm} .\end{array}$} & \multirow{3}{*}{$\begin{array}{l}\text { Oct. } \\
\text { I930 } \\
\mathrm{cm} .\end{array}$} & \multirow{3}{*}{$\begin{array}{l}\text { Nov. } \\
\text { I } 93 \text { I } \\
\mathrm{cm} .\end{array}$} \\
\hline & 1936 & I937 & & & \\
\hline & $\mathrm{cm}$. & $\mathrm{cm}$. & & & \\
\hline $\mathrm{O}_{\mathrm{I}}$ & $\ddot{0} \cdot 5$ & $\ddot{4}$ & $\ddot{8} \cdot 4$ & $\ddot{g} \cdot I$ & 10.3 \\
\hline II & $\begin{array}{r}9.5 \\
15.5\end{array}$ & $\begin{array}{l}\text { II.5 } \\
\text { I6.0 }\end{array}$ & $\begin{array}{r}8.4 \\
14.4\end{array}$ & $\begin{array}{r}9.1 \\
12.7\end{array}$ & $\begin{array}{l}10.3 \\
17 \cdot 4\end{array}$ \\
\hline III & $(19.0)$ & $\begin{array}{l}19.5 \\
\text { S }\end{array}$ & 18.8 & 19.5 & $2 \mathrm{I} \cdot 8$ \\
\hline
\end{tabular}

It is probable that the Plymouth flounders do not grow much until the summer, for the winter fast is not ended until April, and the length-frequency histograms for the earlier months of the year give no indication of an increase in length of the I-group during the first four months of 1936 or of 1937.

The approximate length groupings in April are:

\begin{tabular}{|c|c|c|}
\hline Year-group & $\begin{array}{c}\text { Age } \\
\text { yr. mon. }\end{array}$ & $\begin{array}{l}\text { Length } \\
\mathrm{cm} .\end{array}$ \\
\hline $\mathrm{O}$ & O II & . \\
\hline I & I II & II $\cdot 5$ \\
\hline II & 2 II & 15.5 \\
\hline III & 3 II & \\
\hline IV & 4 II & $(20 \cdot 5)$ \\
\hline
\end{tabular}

That the III-group has a smaller average length than in October, when the fish were some six months younger, is doubtless to be explained by the fact that the larger fish of this group have become sexually mature and gone down to the sea. The figure for the IV-group is probably low for the same reason.

These April figures are consistently smaller than those given by Lübbert \& Ehrenbaum (1936) for April in the Elbe: on the other hand, they agree well with age groupings found by Kändler (1932) on the Oder Bank in the Baltic.

\begin{tabular}{|c|c|c|c|c|}
\hline \multirow[b]{2}{*}{ Year-group } & \multirow[b]{2}{*}{$\begin{array}{c}\text { Tamar } \\
\text { I936 and I937 } \\
\mathrm{cm} .\end{array}$} & \multirow[b]{2}{*}{$\begin{array}{l}\text { Elbe } \\
\mathrm{cm} .\end{array}$} & \multicolumn{2}{|c|}{ Oder Bank } \\
\hline & & & $\begin{array}{l}1925 \\
\mathrm{~cm} .\end{array}$ & $\begin{array}{l}\mathrm{r} 929 \\
\mathrm{~cm} .\end{array}$ \\
\hline 0 & & 8.0 & $4 \cdot 4$ & 4.4 \\
\hline I & II $\cdot 5$ & I $4 \cdot 0$ & $\begin{aligned} & 4+4 \\
& \text { II. }\end{aligned}$ & $\mathrm{II} \cdot \mathrm{I}$ \\
\hline II & 15.5 & $19 \cdot 0$ & 15.5 & $16 \cdot 3$ \\
\hline III & 18.0 & 24.0 & $19 \cdot 35$ & $20 \cdot \mathrm{I}$ \\
\hline IV & 20.5 & .. & $2 \mathrm{I} \cdot 2$ & $23 \cdot 0$ \\
\hline
\end{tabular}


During 1937, many pairs of flounders otoliths were examined, in order to obtain evidence on the year grouping of the fish which would act as an independent check on the conclusions based on length frequencies. It was found that a considerable proportion of the otoliths-as much as $30 \%$ of a samplehad to be rejected as uncertain, either because it was impossible to be sure of the number of rings in the "core" or because there was a discrepancy between the two otoliths of a pair. This possibility of the absorption of one or more opaque rings in the "core" makes it necessary to use great caution in the
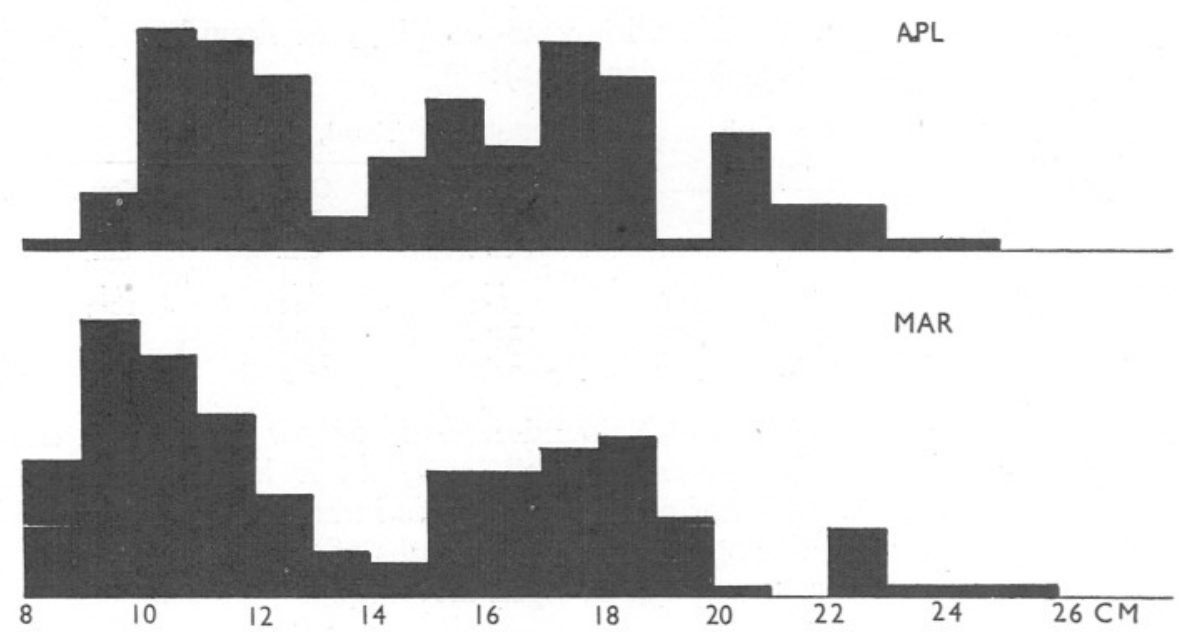

Fig. 6. Pleuronectes flesus; length-frequency distributions, March and April 1936 and 1937.

determination of the year grouping of small numbers of fish by the examination of otoliths. The year grouping by the number of opaque rings was calculated for April 1937 and ${ }^{\star}$ for October-December 1937, and then compared with the lengths of the year-groups as previously determined by the study of histograms.

\begin{tabular}{|c|c|c|c|c|}
\hline \multirow[b]{3}{*}{ Year-group } & \multicolumn{2}{|c|}{ April } & \multirow{2}{*}{\multicolumn{2}{|c|}{ Autumn I937 }} \\
\hline & Histogram & Otoliths & & \\
\hline & $\begin{array}{l}1936 \text { and I } 937 \\
\mathrm{~cm} .\end{array}$ & $\begin{array}{l}\text { I937 } \\
\mathrm{cm} .\end{array}$ & $\begin{array}{c}\text { Histogram } \\
\mathrm{cm} .\end{array}$ & $\begin{array}{l}\text { Otoliths } \\
\mathrm{cm} .\end{array}$ \\
\hline I & II. 5 & II $\cdot 4$ & II $\cdot 5$ & II $\cdot 44$ \\
\hline II & I5. 5 & 14.5 & 15.5 & 17.24 \\
\hline III & $\begin{array}{l}18.0 \\
\end{array}$ & $18 \cdot 2$ & 19.5 & $20 \cdot 7$ \\
\hline IV & $20 \cdot 5$ & .. & ... & .. \\
\hline
\end{tabular}

The agreement between these two sets of figures is sufficiently close to suggest that the approximate age groupings determined from the histograms are substantially correct.

* And by the number of summer zones. 


\section{Feeding Habits.}

The digestive tracts of II 46 estuarine flounders were examined- 462 in I936 and 684 in 1937-and monthly summaries were made of the contents. These summaries are reproduced in Table I, the food organisms being enumerated on a simple basis of occurrence. The diet of the flounder is also shown graphically in Fig. 7. It will at once be seen that crustaceans form the bulk of the food: and within this principal item of diet three species are of paramount importance, contributing more than $80 \%$ of the recognizable crustaceans in each year. Crangon vulgaris formed $42 \%$ of the recognizable

\section{TABle I. PleURONECTES FlESUS: MONTHLy OCCURRENCE OF FOOD ORGANISMS}

The figures give the number of stomachs and intestines containing the specified category of food organism for each month.

Number of fish containing recognizable food Pleuronectes sp.

Gobius minutus and

Gobius sp.

Clupea sp.

Teleost remains

Hydrobia ulvae

Littorina littorea

Cardium edule

Scrobicularia plana

Lamellibranch remains

Chironomid larvae

Cancer pagurus

Carcinus maenas

Leander sp.

Crangon vulgaris

Neomysis vulgaris

Macropsis slabberi

Praunus flexuosus

Schistomysis ornata

Mysid remains

Corophium volutator

Gammarus sp.

Melita palmata

Amphipod remains

Sphaeroma sp.

Gnathiid larvae

Isopod remains

Copepod remains

Crustacean remains

Oligochaete remains

Spirographis spallanzani

Melinna palmata

Sabellaria sp.

Cirratulid remains

Polydora ?hoplura

Glycera sp.

Nereis diversicolor

Polychaete remains

Zostera sp.

Fragments of vegetation

I936

\section{$\overbrace{\text { Jan. Feb. Mar. Apr. May June July Aug. Sept. Oct. Nov. Dec. }}$}

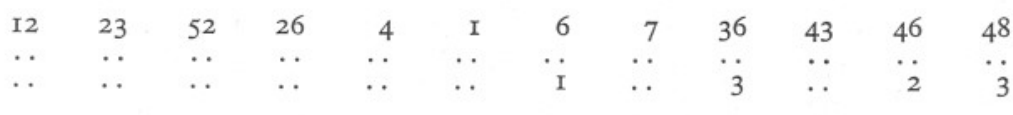




\section{TABLE I (CONTINUED)}

The figures give the number of stomachs and intestines containing the specified category of food organism for each month.

I937

Number of fish containing

recognizable food

Pleuronectes sp.

Gobius minutus and

Gobius sp.

Clupea sp.

Teleost remains

Hydrobia ulvae

Littorina littorea

Cardium edule

Scrobicularia plana

Lamellibranch remains

Chironomid larvae

Cancer pagurus

Carcinus maenas

Leander sp.

Crangon vulgaris

Neomysis vulgaris

Macropsis slabberi

Praunus flexuosus

Schistomysis ornata

Mysid remains

Corophium volutator

Gammarus sp.

Melita palmata

Amphipod remains

Sphaeroma sp.

Gnathiid larvae

Isopod remains

Copepod remains

Crustacean remains

Oligochaete remains

Spirographis spallanzani

Melinna palmata

Sabellaria sp.

Cirratulid remains

Polydora ?hoplura

Glycera sp.

Nereis diversicolor

Polychaete remains

Zostera sp.

Fragments of vegetation

\begin{tabular}{|c|c|c|c|c|c|c|c|c|c|c|c|}
\hline Jan. & Feb. & Mar. & Apr. & May & June & July & Aug. & Sept. & Oct. & Nov. & Dec. \\
\hline 39 & 68 & 59 & 77 & II & I5 & 67 & 5 & 29 & 32 & 28 & 44 \\
\hline$\cdots$ & . & . & . & . & I & . & $\cdots$ & . & . & . & $\because$ \\
\hline 2 & $\ldots$ & 2 & I & . & I & . & 2 & . & I & . & 7 \\
\hline$\ldots$ & $\ldots$ & $\ldots$ & $\cdots$ & $\ldots$ & $\ldots$ & I & $\ldots$ & $\ldots$ & $\ldots$ & $\ldots$ & $\ldots$ \\
\hline 2 & $\ldots$ & $\ldots$ & $\ldots$ & $\ldots$ & $\ldots$ & $\ldots$ & $\ldots$ & $\cdots$ & $\cdots$ & . & 3 \\
\hline$\ldots$ & . & . & . & 2 & . & . & . & . & $\ldots$ & . & . \\
\hline . & $\ldots$ & . & . & . & I & $\ldots$ & . & $\ldots$ & $\ldots$ & . & . \\
\hline$\cdots$ & I & $\ldots$ & . & $\ldots$ & I & $\ldots$ & $\ldots$ & $\ldots$ & . & $\ldots$ & $\ldots$ \\
\hline$\cdots$ & $\cdots$ & $\cdots$ & $\cdots$ & $\cdots$ & . & . & . & $\ldots$ & $\ldots$ & . & . \\
\hline 2 & $\cdots$ & $\cdots$ & I & I & . & I & $\ldots$ & $\ldots$ & $\cdots$ & . & • \\
\hline . & I & $\ldots$ & . & . & . & $\ldots$ & . & . & $\ldots$ & . & . \\
\hline . & . & . & $\ldots$ & $\ldots$ & I & . & $\ldots$ & $\ldots$ & $\ldots$ & $\ldots$ & . \\
\hline I & 2 & 5 & I & 2 & 7 & 4 & I & . & $\ldots$ & I & 4 \\
\hline . & $\cdots$ & $\because$. & $\cdots$ & $\cdots$ & $\cdots$ & I & . & . & $\cdots$ & . & 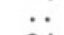 \\
\hline I5 & 24 & I8 & 4 & 4 & 9 & 55 & 4 & I3 & 20 & 4 & 24 \\
\hline$\therefore$ & 2 & 2 & . & . & 3 & 80 & .. & 30 & I & $\ldots$ & I \\
\hline .. & $\cdots$ & $\ldots$ & $\cdots$ & $\ldots$ & . & $\ldots$ & . & 4 & $\ldots$ & $\ldots$ & $\ldots$ \\
\hline$\ldots$ & 2 & $\because$ & 2 & $\cdots$ & $\cdots$ & 9 & . & . & $\ldots$ & $\ldots$ & $\cdots$ \\
\hline IO & I2 & 8 & 30 & 2 & 2 & .. & . & I & $\ldots$ & 4 & 2 \\
\hline 2 & I4 & 7 & 24 & 4 & $\ldots$ & 34 & $\ldots$ & $2 I$ & 2 & I & I \\
\hline . & .. & I & 2 & . & $\ldots$ & . & . & $\ldots$ & I & 6 & 9 \\
\hline$\ldots$ & $\ldots$ & 5 & 3 & . & $\ldots$ & I7 & $\ldots$ & I & $\ldots$ & 2 & 2 \\
\hline$\ldots$ & .. & $\ldots$ & $\ldots$ & $\cdots$ & $\ldots$ & $\ldots$ & $\ldots$ & $\ldots$ & $\ldots$ & $\ldots$ & $\ldots$ \\
\hline I & . & $\ldots$ & $\ldots$ & $\ldots$ & $\ldots$ & 2 & $\ldots$ & $\ldots$ & $\ldots$ & $\ldots$ & 3 \\
\hline . & 4 & $\ldots$ & $\ldots$ & I & $\ldots$ & $\ldots$ & $\ldots$ & $\ldots$ & $\ldots$ & I & . \\
\hline . & $\ldots$ & $\cdots$ & $\cdots$ & $\ldots$ & $\cdots$ & . & $\ldots$ & $\cdots$ & $\ldots$ & $\ldots$ & $\cdots$ \\
\hline . & . & $\ldots$ & $\ldots$ & $\cdots$ & $\ldots$ & $\ldots$ & $\ldots$ & $\cdots$ & $\cdots$ & $\cdots$ & $\ldots$ \\
\hline I & 2 & I & $\ldots$ & $\ldots$ & $\cdots$ & $\cdots$ & $\cdots$ & $\cdots$ & $\ldots$ & I & $\cdots$ \\
\hline I2 & 28 & 24 & 33 & 4 & 5 & 4 & I & 6 & I4 & 6 & I4 \\
\hline . & $\ldots$ & $\ldots$ & $\ldots$ & $\ldots$ & $\ldots$ & .. & $\ldots$ & $\ldots$ & $\ldots$ & I & $\cdots$ \\
\hline$\ldots$ & 4 & 4 & I I & 2 & $\cdots$ & $\cdots$ & $\ldots$ & $\ldots$ & $\cdots$ & $\ldots$ & $\ldots$ \\
\hline I & $\cdots$ & $\cdots$ & $\ldots$ & $\cdots$ & $\ldots$ & $\cdots$ & $\ldots$ & $\cdots$ & $\cdots$ & $\cdots$ & $\cdots$ \\
\hline$\ldots$ & $\cdots$ & $\ldots$ & $\ldots$ & $\ldots$ & $\ldots$ & $\ldots$ & $\ldots$ & $\ldots$ & I & I & $\ldots$ \\
\hline . & $\ldots$ & I & I & $\ldots$ & $\ldots$ & $\ldots$ & $\ldots$ & $\ldots$ & $\ldots$ & I & I \\
\hline$\ldots$ & $\ldots$ & $\ldots$ & $\ldots$ & $\ldots$ & $\ldots$ & $\ldots$ & $\ldots$ & $\cdots$ & $\cdots$ & $\therefore$ & $\cdots$ \\
\hline$\cdots$ & $\cdots$ & $\cdots$ & $\ldots$ & $\cdots$ & $\cdots$ & $\cdots$ & $\cdots$ & $\cdots$ & $\cdots$ & $\cdots$ & $\cdots$ \\
\hline 2 & 5 & IO & 2 & 5 & 5 & 9 & 5 & $\ldots$ & $\ldots$ & $\ldots$ & I \\
\hline 5 & 7 & 6 & 6 & $\ldots$ & 2 & I2 & I & $\ldots$ & 2 & 7 & 2 \\
\hline$\cdots$ & $\ldots$ & $\ldots$ & $\ldots$ & $\ldots$ & $\ldots$ & $\ldots$ & $\ldots$ & $\ldots$ & $\cdots$ & $\ldots$ & $\cdots$ \\
\hline 2 & $\cdots$ & $\ldots$ & $\ldots$ & $\ldots$ & $\cdots$ & $\ldots$ & $\ldots$ & $\cdots$ & I & $\cdots$ & I \\
\hline
\end{tabular}

species in 1936 , and $32 \%$ in 1937. Mysidacea were the other important crustacean food, contributing $43 \%$ of the recognizable forms in 1936, and $52 \%$ in 1937; and in each year just over $90 \%$ of the identifiable mysids belonged to two species, Neomysis vulgaris and Schistomysis ornata. Of the polychaetes only Nereis diversicolor and Spirographis spallanzani were of much importance as articles of diet. The remains of Scrobicularia plana were merely the tips of the siphons neatly nipped off; one fish contained twenty-nine. Gobius minutus and other small teleosts and Carcinus maenas were eaten in numbers by the largest fish, but were too big to form a valuable supply of food for the bulk of the population. 
Patterson (I904 $a$, I906, I907) laid emphasis on the importance of shrimps in the diet of the flounders of Breydon Water, and also mentioned molluscs, young herrings and Ulva lactuca as foods. Scott (1895) found that the food of flounders on the Lancashire coasts was made up of $33 \%$ annelids and $60 \%$ crustaceans in I894, but entirely of annelids in I895. Five years later, Ascroft (1900), in the same area, found that "the food of the Flounder consists principally of worms and crustacea. It is very fond of Corophium longicorneit also eats a quantity of bivalve molluscs and freshwater snails." Murie (1903) in the Thames estuary found that the flounders were feeding on crustaceans and polychaetes, with some bivalves.

Of workers on the fish of continental waters, Lübbert \& Ehrenbaum (I936) found that flounders in the mouth of the Elbe fed largely on crustaceans, supplemented by gastropods, mussels, larvae of aquatic insects, polychaetes

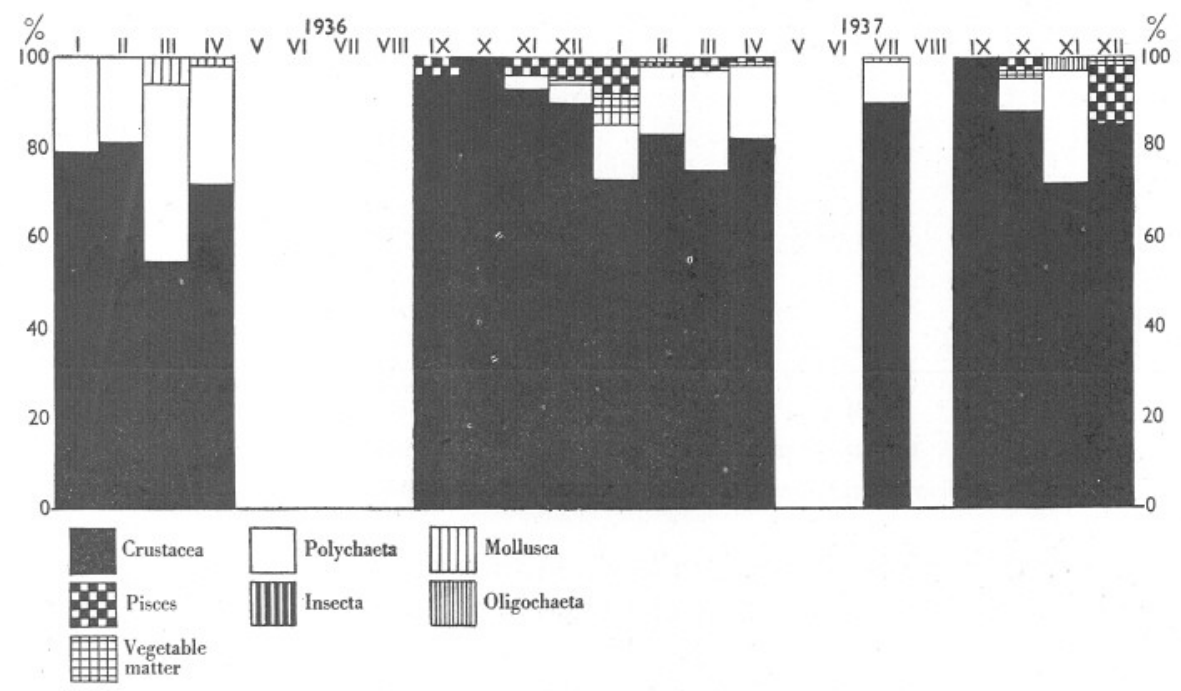

Fig. 7. Pleuronectes flesus; monthly variations in diet. (No figures are given for months in which less than 25 fish were examined.)

and such small fishes as Gobius, Ammodytes and clupeoids. In general this dietary is very similar to that of the Tamar fish. In the fresh waters of the Elbe (Stadel, I936) tubificid worms and sphaeriid molluscs were the food of flounders over I $5 \mathrm{~cm}$. in length; while the smaller fish ate tubificids, with some copepods in summer. In the Baltic, Blegvad (1932) found that the O-group flounders fed largely on crustaceans, the I-group on crustaceans and chaetopods and the II and older groups chiefly on molluscs, with some crustaceans and comparatively few annelids. In the Dybsø Fjord, Larsen (I936) showed Cardium exiguum, C. edule, Idotea viridis and Gammarus locusta to be the food organisms most commonly occurring: the flounders of this fjord ate no polychaetes. 
In the winter there is a marked period of fasting (Fig. 8). Feeding does not cease entirely, but the number of fish containing food drops from 90-100 \% in September to $30-40 \%$ in January. In the winter of $1937-8$ the fast began earlier than in the preceding year, for in November 1937 only $44 \%$ of the fish contained food as compared with $78 \%$ in the same month of the previous winter. The difficulty of obtaining fish in the early summer makes it impossible to say when the fast is ended, but the fact that in April $193780 \%$ of a sample of ninety-nine flounders contained food, suggests that the period of full feeding must have been near at hand.

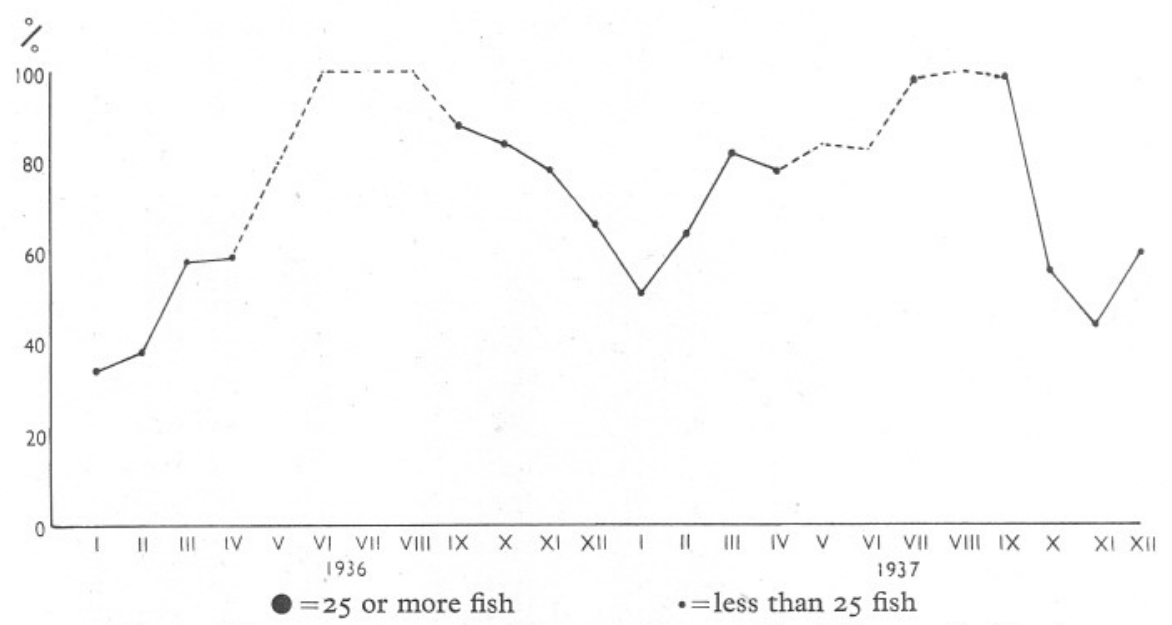

Fig. 8. Pleuronectes flesus; monthly percentages of fish which contained food.

The smaller fish are the first to begin fasting. In the winter of 1936-7 the arithmetic means of the lengths of the empty fish and of the whole sample were:

$\begin{array}{lcc} & \text { Empty fish } & \text { Whole sample } \\ \mathrm{cm} . & \mathrm{cm} . \\ \text { Nov. } 1936 & 15.7 & 19 \cdot 3 \\ \text { Dec. } 1936 & 15.5 & 16.7 \\ \text { Jan. 1937 } & 18.1 & 17.9 \\ \text { Feb. 1937 } & \text { 17.0 } & 16.8\end{array}$

The maturing fish continue to feed during the fast of the immature flounders which will remain in the estuary; the fast of the spawners will come later, when they have gone down to the sea to breed. In December 1937 and January 1938 ten out of thirteen ripening males and fourteen out of sixteen ripening females had fed, while only $59 \%$ in December and $44 \%$ in January of the whole population contained food. Stadel (1936) concluded that there was no pause in the feeding of the flounders living in the fresh waters of the Elbe, but he had examined no fish in January or February: moreover, he 
mentions that Ladiges had obtained evidence that there was a winter fast in flounders of II-II $5 \mathrm{~mm}$.

The fast of the spawning flounders in the sea is prolonged, and the cessation of feeding is more complete than within the estuaries. Of I40 mature flounders trawled off Plymouth between January and April, only three contained food: these were two females and a male caught in February I937 with remains of crustaceans in their stomachs.

During the fast the gut may become tightly contracted and stained green with bile. In many fish, on the other hand, the intestine is filled with gritty, black mud, containing no remains of animal or fresh vegetable matter. This mud is not found in the stomach in any quantity, suggesting that it is not deliberately swallowed: it may be that particles of mud engulfed in the process of respiration tend to accumulate in the gut owing to a slowing down of peristalsis during the fasting period.

\section{Breeding Habits.}

Flounders are typical catadromous fish: they feed and grow in fresh and brackish waters until the onset of sexual maturity, when they go down to the sea to breed. In the Tamar and Lynher the gonads begin to develop in November; most of the ripening fish leave the estuaries in January, and all have gone before the end of February. Off Plymouth they are caught at sea from the latter half of January until the end of April, being trawled in 20-30 fathoms of water on the "Rame Mud", "Corner" and "Looe-Eddystone" grounds. Cunningham (I896) has remarked that flounders are rarely found in more than 30 fathoms of water. Some spent females return to brackish water, but no spent males have been taken within the estuaries. Fish which remain in the sea after breeding feed and grow and come again to the spawning grounds, but it has proved impossible to trace their distribution during the period of recovery and growth. Captain Lord of s.s. Salpa tells me that flounders are rarely trawled out of the breeding season, except for an occasional fish taken after heavy autumn floods. It may be that the sea fish move close inshore after spawning, for a long-line fisherman in Whitesand Bay told me that he caught some flounders on the sandy shallows there. Ehrenbaum (I9II) found a migration of spent flounders from the Bornholm deeps towards the Pomeranian coast.

The arithmetic mean length of the sea-caught female flounders in 1937 was $34.6 \mathrm{~cm}$., that of the mature females caught in the estuaries in the winter of I936-7 only $27 \cdot 9 \mathrm{~cm}$. If all the spent female flounders returned to brackish water after each breeding season, it might reasonably be expected that the arithmetic mean lengths of the ripening fish within the river in any winter, and of the mature fish in the sea outside in the following spring, would be approximately the same. The actual difference of $6.9 \mathrm{~cm}$. suggests that only a small proportion of the spent females do, in fact, return to the estuaries: this is in 
accordance with the findings of Schnackenbeck (I926) and Ehrenbaum (I929). The smallest mature female taken measured $2 \mathrm{I} \cdot 2 \mathrm{~cm}$. So far as otolith readings may be trusted, the female flounders of the Tamar and Lynher become mature in their fifth winter.

The spawning period is apparently a long one. The walls of the ovary often represent a speckled appearance, for little knots of clear, ripened eggs lie in the opaque mass of less developed ova. A similar state has already been described by Steven (1938) in the mackerel, Scomber scombrus. As the number of the ripe eggs increases they collect in the anterior part of the gonad, which projects into and almost fills the body cavity, pressing the empty flaccid gut against the septum transversum. At this stage the anterior, lower part of the ovary is uniformly translucent, the posterior part uniformly opaque. The capture of half-empty females also suggests that there is not a single, continuous oviposition, but rather a succession of spawnings as batches of ripe eggs are accumulated. A completely spent female has been caught in the middle of February and a fish still very full of eggs in mid-April. Russell (1930, 1937) has found post-larval flounders off Plymouth in March, April, May and June.

Male flounders mature in their fourth and fifth winters, the two age groups contributing more or less equally to the recruitment of the spawning stock. The Plymouth fish not only grow more slowly than those of the Elbe, but mature later, for Ehrenbaum (I929) found that most of the males in German waters became sexually mature at the end of their third year. The arithmetic mean length of the mature male river fish in the winter of I $936-7$ was $23.5 \mathrm{~cm}$., the smallest measuring $18.2 \mathrm{~cm}$. and the largest 27.4 . The mean length of the sea-caught males in the spring of 1937 was $28.05 \mathrm{~cm}$. No spent males were caught in the estuaries; and the difference in the mean lengths of the seacaught and river-caught fishes suggests that there is no extensive return to brackish waters after spawning.

The otoliths of sea-caught flounders seem to be even more unreliable than those of river fish in the determination of the age of individuals. It may be that the strain of spawning, and the change from an estuarine to a marine life so alters the metabolism of some fish that the regular laying down of summer and winter rings ceases or is at least interrupted. The largest number of winter rings found in any fish is seven.

Changes in Condition through the Year.

During 1937 the condition factor, $k$, was calculated for each flounder from the formula

$$
k=\frac{W \times 1000}{l^{3}},
$$

where $W=$ weight in g., $l=$ length in $\mathrm{cm}$.

The variation in condition from month to month is shown in Figs. 9 and ro, 


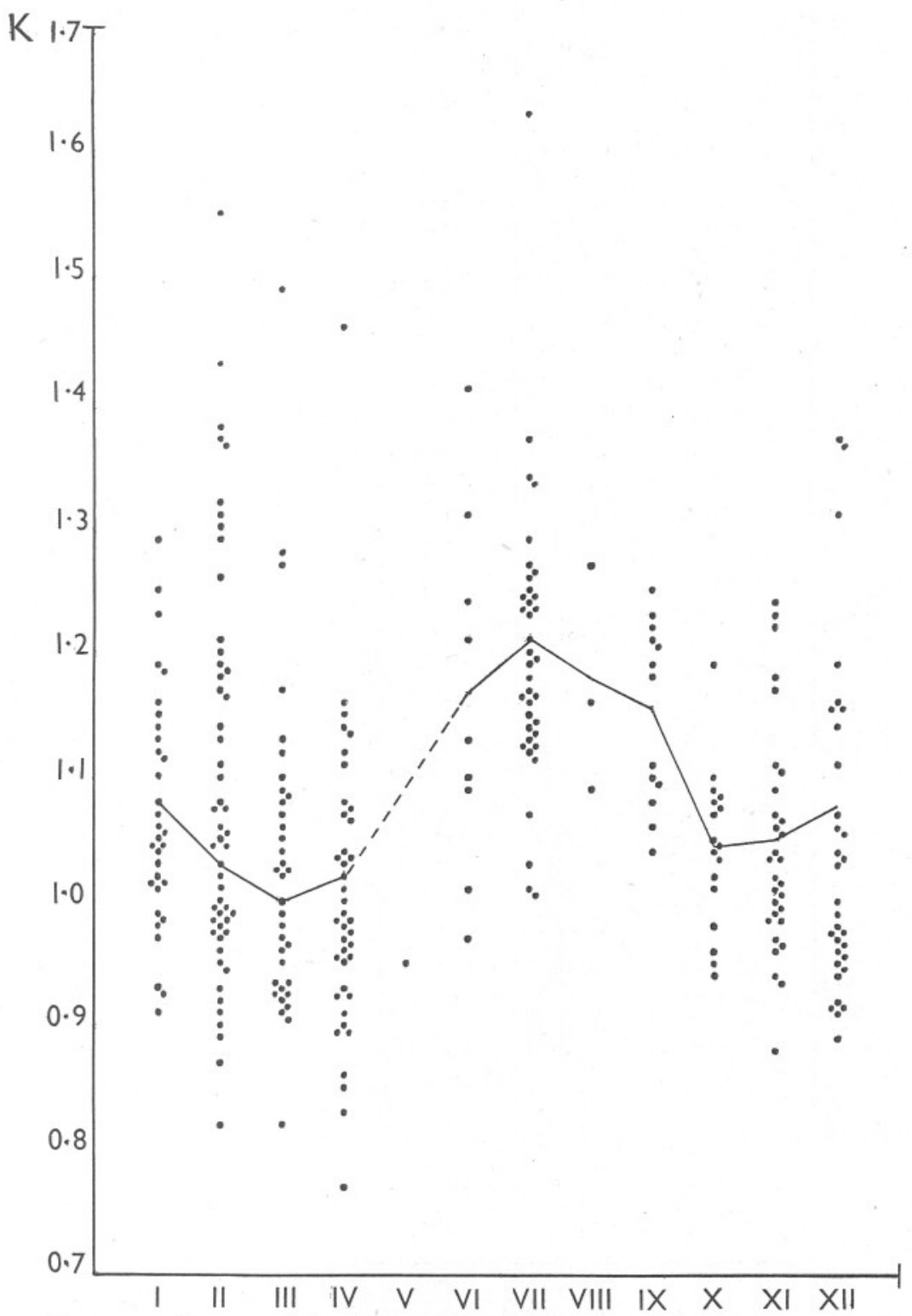

Fig. 9. Pleuronectes flesus; condition factors of female fish, I937. (The mean condition factors for each month are joined by a line.) 


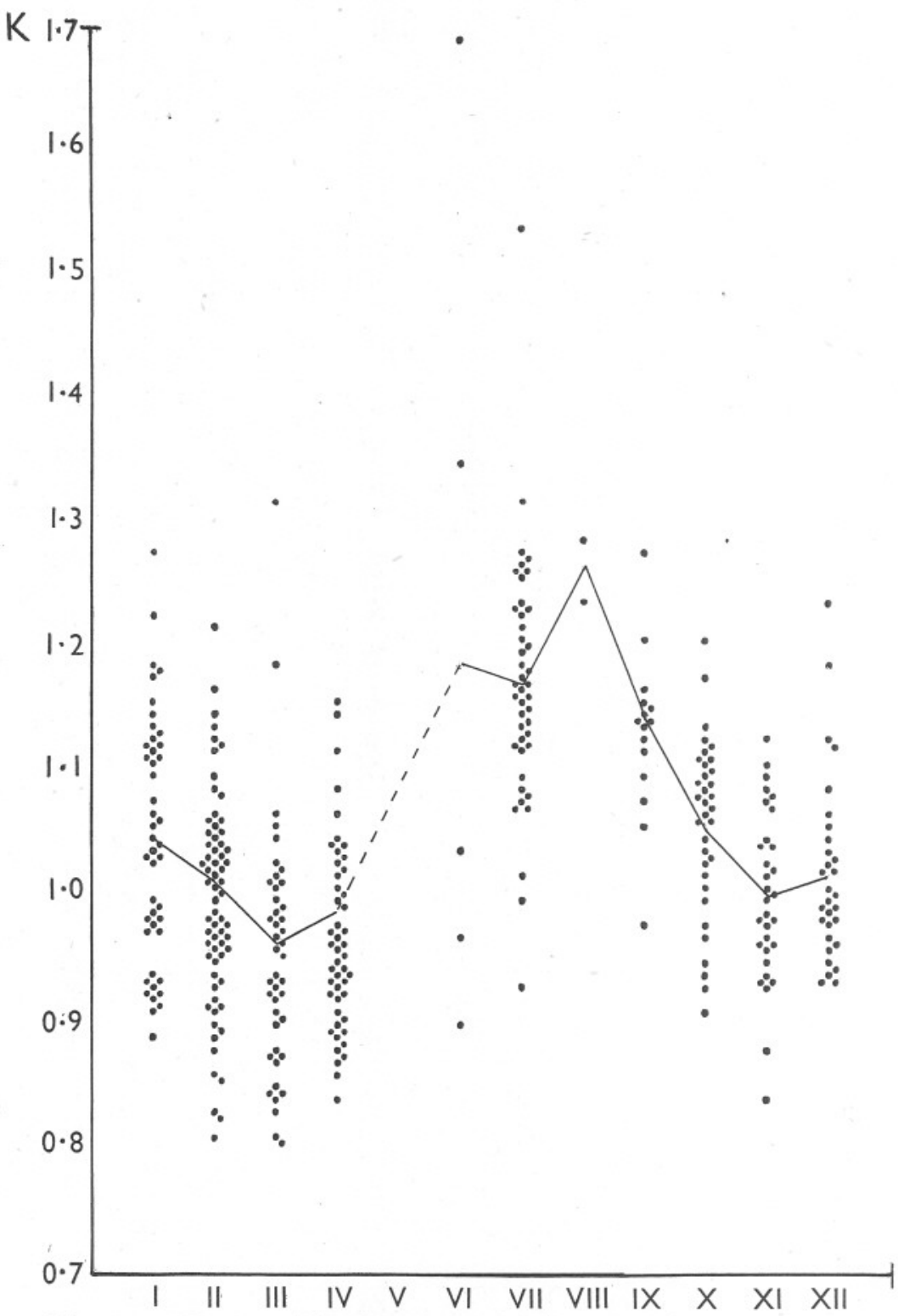

Fig. 10. Pleuronectes flesus; condition factors of male fish, 1937. (The mean condition factors for each month are joined by a line.) 
while the following table shows the mean monthly condition factors for each sex.

Month
I937
Jan.
Feb.
Mar.
Apr.
May
June
July
Aug.
Sept.
Oct.
Nov.
Dec.

\begin{tabular}{|c|c|}
\hline \multicolumn{2}{|c|}{$k$, females } \\
\hline River & Sea \\
\hline & \\
\hline $10 \cdot 28$ & I3. 3 \\
\hline 9.93 & 12.0 \\
\hline 10.02 & 10.5 \\
\hline$(9.57)$ & $\ldots$ \\
\hline$(\mathrm{II} \cdot 7)$ & .. \\
\hline I2.03 & .. \\
\hline$(\mathrm{II} \cdot 75)$ & . \\
\hline II 56 & $\ldots$ \\
\hline 10.45 &.. \\
\hline 10.54 & . \\
\hline $10 \cdot 76$ & $\ldots$ \\
\hline
\end{tabular}

\begin{tabular}{|c|c|}
\hline \multicolumn{2}{|c|}{$k$, males } \\
\hline River & Sea \\
\hline 10.46 & . \\
\hline 10.15 & 10. 45 \\
\hline 9.63 & 9.58 \\
\hline $9.9 \mathrm{I}$ & $9 \cdot 25$ \\
\hline$(\mathrm{ri} \cdot 95)$ & .. \\
\hline II. 77 & $\cdots$ \\
\hline (I2.75) & \\
\hline II 45 & . \\
\hline 10.68 & \\
\hline 10.05 & .. \\
\hline 10.23 & .. \\
\hline
\end{tabular}

Flounders of both sexes were poorest in condition in March, towards the end of the winter fast: there was a rapid improvement in the early summer and both sexes were at their best about July. In September they had begun to go back, although all were still feeding. With the beginning of the fast in October the decline in condition became more rapid. The continued feeding of the ripening fish through the last months of the year tends to raise the mean condition factor until the time comes for the spawners to go down to the sea. This is especially marked in the females, whose weight increases enormously with the development of the ova. The difference in $k$ of sea-caught and rivercaught fish in February and March clearly illustrates this. As the spawning proceeds the weight of the females rapidly decreases, until by midsummer the poorest of the river flounders are the light-weight fish which have returned from the sea.

Ripening males do not show so great an increase in weight in comparison with the immature fish. The strain of spawning seems to tell heavily upon them, for spent fish caught at sea are among the worst conditioned fish examined. It may be that spawning is a greater strain on the males than on the females, with the result that they die younger. It has already been shown that the larger breeding fish are females.

\section{Daily Movements.}

It is not possible to make equally good catches of flounders at all hours of the day. On some grounds several shots may be made in the morning or at midday, and only a dozen fish will be captured. In the late afternoon the fishing will be no better, until the time comes when the daylight begins to fade. A shot made then will sweep up three or four score of fish. On the Butterfly ground, just above Saltash, I have made hauls over the same area, separated by only a quarter of an hour: the first yielded no flounders at all; the next, made at the "change of light", contained seventy fish, and one made immediately after about fifty. There must have been a sudden and rapid inshore movement of 
the flounders. There is great competition among the fishermen for the right of making the first haul at "change of light" on a good dusk ground; the first boat may arrive half an hour before sunset. When more than one boat is working on a ground of limited extent, shots are made in turn, and the later arrivals must not start work until the first crew have hauled their net. The flounders do not stay along the tide edge all night: the fishing at midnight on the best of the dusk grounds is little better than at midday. When surface drift nets are set for the herring at dusk, flounders are frequently taken in them. In October I937 a marked fish was caught by its mark in a surface net, some $50 \mathrm{ft}$. ( $15 \mathrm{~m}$.) above the bottom. The flounder does not at any time limit itself to the bottom in its search for food-Patterson (1904a) has remarked on its activity in shrimp hunting, often near the surface; but this evening movement of so many fish up the slopes of the mud-banks and towards the surface, with the subsequent scattering during hours of darkness, is very reminiscent of the following of an optimum of illumination by planktonic organisms (Russell, 1926). It may be that the fish are moving under the influence of the same stimulus, or combination of stimuli, that orders the daily movements of so many small invertebrates.

\section{"Left-Sided" Fish.}

The flounder is peculiar among pleuronectids in the regular occurrence of left-sided fish, or "flukes", that is, fish in which the eyes have moved to the left side on metamorphosis instead of to the right, and in which the left side is pigmented and the right side colourless. Of 2363 flounders examined in I936-7, I26 fish ( $5.33 \%$ ) were left-sided. Duncker (I899) investigated II20 fish from the Tamar and found the proportion of left-sided specimens to be $5.36 \%$. The close agreement of these two figures, separated by an interval of nearly 40 years, is striking and suggests that the proportion of "flukes" may be a racial character of a population of flounders. Lübbert \& Ehrenbaum (I936) state that in the Baltic about $35 \%$ of the flounders are "flukes" and that the proportion in the Black Sea is scarcely half that figure. They put forward the suggestion that the proportion of left-sided fish increases from the south to the north of the species' range; but the consistently low percentage of "flukes" in the west of England seems to be against this view.

\section{Pleuronectes limanda L., the Dab}

On the fishing grounds nearest to the sea, dabs are the most numerous of the flatfishes: and they are entirely confined to these seaward grounds. Flounders will press upstream into fresh water, young plaice, brill and soles are regularly found in the brackish conditions of the Sheviock Wood ground, but the dabs remain in the essentially marine environment of the Hamoaze and the neighbourhood of Saltash. (Professor de Beaufort, of Amsterdam, informs 
me that in the Zuyder Zee, before the construction of the enclosing dykes, dabs showed a similar distribution, being found in the marine conditions near the open sea, and never venturing so far into brackish waters as the plaice were wont to do.)

\section{Growth and age.}

The growth of the dab during its estuarine life was studied by means of length-frequency histograms, by the calculation of arithmetic mean lengths of discrete length-groups and by some examination of otoliths.

In the winter of $1935^{-6}$, the dabs showed a group of small fish with a modal length of about $6 \mathrm{~cm}$., and a second, less compact, group with a modal length of I $3 \mathrm{~cm}$., and a length dispersion from 8.0 to $23 \mathrm{~cm}$. (Fig. I I $a$ ). In March I936 the larger group was suddenly very much reduced in numbers, so that the smaller fish, with a modal length of $6-7 \mathrm{~cm}$. came to dominate the catches (Fig. I I $b$ ). Through the spring and early summer this one length-group was caught; the average length increased. At the same time the dispersal of the lengths became greater. In July 1936 a new length-group appeared (Fig. I I c), with an arithmetic mean length of $3.86 \mathrm{~cm}$. By October 1936 this length had increased to $5.7 \mathrm{~cm}$., while the fish in the preceding group were mostly between I 2 and I $7 \mathrm{~cm}$. in length (Fig. I I $d$ ). Neither the "small" nor "large" groups showed marked increase in length through the winter of I936-7 (Fig. II $e$ ). In March 1937 the reduction of the larger group was again seen (Fig. II $f$ ), and the story of the recruitment in summer, and increase in length and length-dispersal of the preceding group was repeated. In 1937 the recruitment took place in June, and was on a much smaller scale than in the previous year; the small fish were only well represented in June and December (Figs. II $g, h$ ).

The study of the growth of the dab was made easier by the fact that it was possible to catch the juvenile fish while they were still very small, and to follow their development until they were about a year old. To some extent the difficulty of fixing modes in length-frequency histograms was encountered, but the comparatively short period spent by most dabs in the estuaries made this source of uncertainty of considerably less importance than in the flounder.

Examination of Fig. II, with its repeated story of the sudden reduction of the larger of two size groups, suggests the possibility that the majority of the Tamar dabs remain for a little under two years in the estuaries and then go down to the sea.

The development of a year-group can best be traced in the growth of the recruitment of 1936. In that year post-larval dabs were most numerous off Plymouth in May (Russell, I937), so that the young fish caught in the estuaries in July were about two to three months old; the arithmetic mean length of the year-class was then $3.86 \mathrm{~cm}$. This length group was quite 


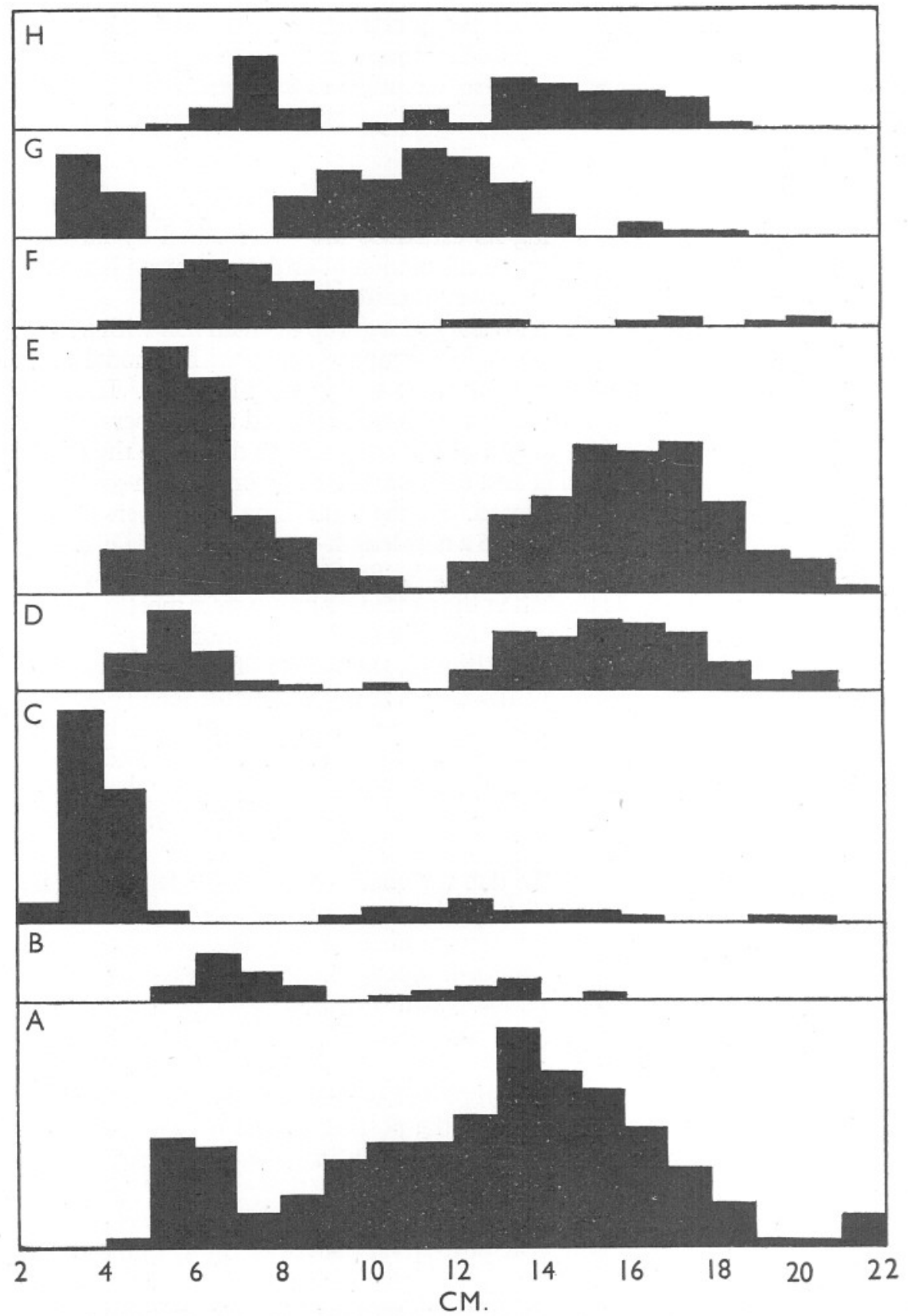

Fig. II. Pleuronectes limanda; length-frequency distributions. A, November I935-February 1936; $B$, March 1936; $C$, July 1936; $D$, October 1936; $E$, November 1936-February I937; $F$, March I937; $G$, June and July I937; $H$, December 1937. 
distinct from that of the preceding classes until April 1937. The growth of these O-group fish in their first year can, therefore, be shown below:

\begin{tabular}{|c|c|c|c|c|c|c|c|c|c|}
\hline \multirow[b]{2}{*}{$\begin{array}{l}\text { Month } \ldots \\
\text { Arithmetic } \\
\text { mean length } \\
\text { in } \mathrm{cm} \text {. }\end{array}$} & \multicolumn{6}{|c|}{ I936 } & \multicolumn{3}{|c|}{ I937 } \\
\hline & $\begin{array}{l}\text { July } \\
3.86\end{array}$ & $\begin{array}{l}\text { Aug. } \\
4.02\end{array}$ & $\begin{array}{c}\text { Sept. } \\
5.0\end{array}$ & $\begin{array}{c}\text { Oct. } \\
5.7\end{array}$ & $\begin{array}{c}\text { Nov. } \\
6 \cdot 2\end{array}$ & $\begin{array}{l}\text { Dec. } \\
6.4 \mathrm{I}\end{array}$ & $\begin{array}{l}\text { Jan. } \\
6.24\end{array}$ & $\begin{array}{l}\text { Feb. } \\
7 \cdot \mathrm{I} 4\end{array}$ & $\begin{array}{l}\text { Mar. } \\
7 \cdot 2\end{array}$ \\
\hline
\end{tabular}

It will be seen that there is little increase in length in midwinter.

The 1937 class fish were scarcer than those of 1936 ; only twice during the first nine months of their O-group year were adequate samples obtained, in late June, and in December I937 (Figs. II $g, h$ ). In June they had an arithmetic mean length of $3.82 \mathrm{~cm}$.; by December they had grown to $7.43 \mathrm{~cm}$. This was just $\mathrm{I} \mathrm{cm}$. longer than the preceding $\mathrm{O}$-group in that month, and also larger than the O-group fish of the 1935 class, which in December had a mean length of $6.5 \mathrm{~cm}$.

It will be seen (Figs. II $b, f$ ) that all the fish of the larger year-group do not go down to the sea in spring. After the summer growth period has begun it is no longer possible to distinguish I-group fish from the laggards of the IIgroup. It is of course probable that the larger fish of the "big" length-group will belong to the II-group-there is some evidence for this from examination of otoliths-but the distinction can no longer be made from length groupings. On the other hand, a large year-class will, as I-group fish, strongly dominate the "big" length-group, although they do not entirely compose it. In June and July 1937, the mean length of the "big" group was II.65 cm.; by December it had increased to $14.4 \mathrm{~cm}$. These figures are, at least, rough approximations to the growth of the I-group fish during their second year of estuarine life.

In the autumn of 1937 some dab otoliths were examined. They proved to be more legible than those of flounders, showing the broad, well-marked summer zones. Samples of 3-zone fish were always small, but in general they were longer than the 2-zone class. The arithmetic mean length of all 3-zone fish examined between September and December 1937, was 19.94 cm. The arithmetic mean lengths of the 2-zone, which usually formed the bulk of the samples, were:

\begin{tabular}{|c|c|}
\hline Month & $\begin{array}{c}\text { Arithmetic mean } \\
\text { length } \\
\mathrm{cm} .\end{array}$ \\
\hline Sept. & 13.93 \\
\hline $\begin{array}{l}\text { Oct. } \\
\text { Noy }\end{array}$ & I4.83 \\
\hline Nov. & $\begin{array}{l}\text { I4.97 } \\
\end{array}$ \\
\hline Dec. & 15.0 \\
\hline
\end{tabular}

The very slight length increment in the winter months suggests that growth ceases during the fasting period.

Only one good sample of I-zone dabs was obtained: this was in December 1937 the only month after June in which the O-group, as determined by 
length frequencies, was well represented. The arithmetic mean length of these I-zone fish was $7 \cdot 7 \mathrm{~cm}$. A single 4-zone dab was examined-a male of $26.9 \mathrm{~cm}$., with testes showing no sign of ripening-on December 8 .

The close correspondence between the average mean length of the O-group fish as determined by length frequencies $(7.43 \mathrm{~cm}$.) and by examination of the otoliths $(7 \cdot 7 \mathrm{~cm}$.) and the agreement between the mean lengths of the 2-zone or I-group fish $(\mathrm{I} 5.0 \mathrm{~cm}$.) and the approximation reached on the basis of the dominance of I-group fish in the "big" group ( $14.4 \mathrm{~cm}$.) allow the following summary of the growth of estuarine dabs to be put forward:

In their first year dabs grow to a length of 6-7 cm.: there is a slowing down of growth in the winter months. In their second year the fish reach a length of $\mathrm{I} 4-\mathrm{I} 5 \mathrm{~cm}$., and growth again ceases in the fasting period. In this second year some males begin to mature (in December $193768 \%$ of the I-group males were ripening). Most dabs go down to the sea when just under two years old, but a few remain in the estuaries for a third summer, and grow to a length of $20-2 \mathrm{I} \mathrm{cm}$.

The growth of the dab in the Plymouth area is considerably greater than that found by Poulsen (1933) in Danish waters:

Length in $\mathrm{cm}$.

\begin{tabular}{ccccccc}
\cline { 3 - 6 } Year & $\begin{array}{c}\text { Plymouth } \\
\text { area }\end{array}$ & $\begin{array}{c}\text { Horn's } \\
\text { Reef }\end{array}$ & $\begin{array}{c}\text { West } \\
\text { Limfjord }\end{array}$ & Kattegatt & Belt Sea & Baltic \\
I & $6-7$ & 4 & 5 & $5 \cdot 5$ & 5 & $3 \cdot 8$ \\
2 & I4-I5 & $8 \cdot 4$ & II & $12 \cdot 3$ & II.8 & 8 \\
3 & $20-2$ I & I5.2 & I7 & $19 \cdot 3$ & I7.5 & I5
\end{tabular}

Poulsen found that the Danish dabs were "keen competitors" with plaice for their food. In the Tamar and Lynher, as described below, the dabs live largely on organisms exploited by no other fish: it may be that a greater abundance of available food accounts for swifter growth in these rivers.

At the run to the sea, the majority of the two-year-old males are sexually adult. In December $193768 \%$ of the I-group males had ripening gonads, a figure which corresponds closely with Poulsen's finding that in the Baltic $70 \%$ of the two-year-old males were mature. No I-group females were sexually mature: Wheeler (1924) states that female dabs off Plymouth become adult at the end of the third year, and Poulsen found first maturity at the same age in Danish waters.

\section{Feeding Habits.}

During their estuarine life dabs change their feeding habits as they grow. The small fish of the O-group feed almost entirely on crustaceans, juvenile mysids and copepods, but when they reach a length of $7 \mathrm{~cm}$. (that is, when 
about 9 months old) small polychaetes begin to enter into their diet, and by the time they reach a length of $9 \mathrm{~cm}$. marine worms form the bulk of their food.

Change in Diet of Dab with growth: 1936

Polychaetes and crustaceans, expressed as percentages of total occurrence of polychaetes + total occurrence of crustaceans.

$\begin{array}{rcc}\begin{array}{c}\text { Length } \\ \text { cm. }\end{array} & \begin{array}{c}\text { Polychaetes } \\ \%\end{array} & \begin{array}{c}\text { Crustaceans } \\ \%\end{array} \\ \text { I9-24 } & 69 & 31 \\ \text { I8 } & 80 & 20 \\ \text { I7 } & 68 & 32 \\ \text { I6 } & 75 & 25 \\ \text { I5 } & 69 & 31 \\ \text { I4 } & 65 & 35 \\ \text { I3 } & 85 & 15 \\ \text { I2 } & 72 & 28 \\ \text { I1 } & 57 & 43 \\ \text { I0 } & 57 & 43 \\ 9 & 58 & 42 \\ 8 & 40 & 60 \\ 7 & 43 & 57 \\ 6 & 22 \cdot 3 & 77 \cdot 7 \\ 5 & 20 & 80 \\ 4 & \cdots & 100 \\ 3 & \cdots & 100 \\ 2 & . & 100\end{array}$

For the rest of their life in the river mouths, a sabellid worm, Spirographis spallanzani, is the most important food organism. A dab which has been feeding on this polychaete is often distended with the crowns and pieces of the body. It seems that the worm is either extracted from its muddy flexible tube, or else the crown of tentacles and the anterior segments are bitten off short: pieces of the tube are uncommon in the gut. Steven (1930) found that the dab was in the habit of making a sudden snap at tubicolous polychaetes, its "pounce" being horizontal, rather than vertical as in the lemon sole (Pleuronectes microcephalus). Even when too small to take a whole crown, a $5 \mathrm{~cm}$. dab will nip off a few spirographid tentacles. Some crustaceans are taken by the larger fish. In general, dabs eat a greater variety of food organisms than any other estuarine fish. Fig. I2 and Table II show the changes in the food of the dab from month to month. The predominance of crustaceans in the diet in July and August 1936 and August 1937, is due only in part to the exclusively crustacean food of the small O-group fish. The larger fish show a change in feeding habits during the summer, eating more shrimps and mysids, and fewer worms. The dab is the only fish in the estuary which feeds regularly on hydroids; when this food could be identified it was always Gonothyrea loveni. At times, small spawn masses were found in the guts of dabs: these could not be identified with any certainty, but seemed to belong to some mollusc, perhaps Archidoris, which is common in the lower tidal reaches. Dabs took some food which had fallen or been washed into the river from the land, a large slug, a 
spider, a hawthorn berry and seeds of grasses and an umbellifer were found in different fish.

In the Thames estuary, Murie (1903) found that "the dab's food is quite varied in character, depending somewhat on the time of year, and much on the locality where fished". He listed young shrimps, mysids, amphipods, crabs, worms, young mussels, Sertularia, echinoderms and fish as food organisms. Scott (1895) found that on the Lancashire coast, annelids and a smaller quantity of crustaceans were the most important foods of dabs less than 3 in., and that molluscs occurred in $20 \%$ of the larger fish in I894, and $34 \%$ in I895. He found that dabs took some echinoderms, but that plaice and flounder did not. Poulsen (I933) regarded the dabs of Danish waters to be "keen competitors" of the plaice, and on calculations based on the work of Blegvad estimated that molluscs made up $37 \%$ of the food, annelids $21 \%$, crustaceans $12 \%$ and "other groups" $30 \%$. He found that these "other groups" made up only $0.1 \%$ of the food of the plaice, a fact which suggests a more varied diet for the dab.

The estuarine dabs fast to some extent in winter (Fig. 13): this fasting period is less regular than in the flounder and plaice. In 1936 there were two months, October and December, in which less than $60 \%$ of the dabs examined contained food; but in November $79 \%$ of the fish had been feeding. In I 937 only

\section{Table II. Pleuronectes limanda: Monthly Occurrence of Food Organisms.}

The figures give the number of stomachs and intestines containing the specified category of food organism for each month.

I936

Number of fish containing

recognizable food

Hydrobia ulvae

Carcinus maenas

Eupagurus bernhardus

Crangon vulgaris

Decapod larvae

Schistomysis ornata

Neomysis vulgaris

Mysid fragments

Pariambus typicus

Caprellid fragments

Gammarus locusta and

Gammarus sp.

Corophium volutator

Amphipod fragments

Copepod fragments

Crustacean fragments

Spirographis spallanzani

Cirratulid fragments

Polydora sp.

Polychaete fragments

Oligochaeta indet.

Gonothyrea loveni

Hydroid remains

"Spawn"

Vegetable matter
Jan. Feb. Mar. Apr. May June July Aug. Sept. Oct. Nov. Dec.

\begin{tabular}{|c|c|c|c|c|c|c|c|c|c|}
\hline $5 \mathrm{I}$ & $3 I$ & 42 & 47 & 4 & 52 & 27 & 34 & 2 & 30 \\
\hline$\cdots$ & $\cdots$ & $\cdots$ & I & .. & I & $\cdots$ & .. & . & I \\
\hline I & $\because$ & $\cdots$ & 2 & . & 2 & $\cdots$ & $\cdots$ & . & $\because$ \\
\hline$\ddot{I}$ & $\because$. & $\begin{array}{l}\cdots \\
\cdots\end{array}$ & $\begin{array}{l}1 \\
3\end{array}$ & $\ddot{I}$ & $\begin{array}{l}4 \\
5\end{array}$ & $\ddot{I}$ & $\ddot{2}$ & & is \\
\hline. & $\ldots$ & $\ldots$ &. & $\ldots$ & $\therefore$ & 3 & . & . &. \\
\hline I & I & 4 & 7 & $\cdots$ & 3 & 3 & & & . \\
\hline I & $\cdots$ & 4 & $\ddot{\sim}$ & 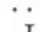 & 22 & I & 3 & & 2 \\
\hline$\ldots$ & 3 & 4 & 14 & . & 11 & 5 & 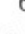 & & \\
\hline$\ldots$ & I & $\ldots$ & $\ldots$ & $\ldots$ & . & 4 & & . & . \\
\hline$\ldots$ & $\cdots$ & 4 & I & .. & I & 6 & . & . & 5 \\
\hline . & 3 & 2 & 2 & I & I & $\ldots$ & . & & \\
\hline 2 & I & 2 & 6 & . & 2 & 3 & . & & 3 \\
\hline 4 & I5 & I I & & . & 5 & I4 & & & 2 \\
\hline 2 & 3 & I0 & I5 & 2 & I8 & 6 & $\theta$ & & 7 \\
\hline 56 & 24 & 40 & $6 \mathrm{I}$ & 2 & 26 & .. & 3 & I. & I3 \\
\hline$\ddot{I}$ & I & $\cdots$ & $\cdots$ & $\cdots$ & $\cdots$ & ". & $\cdot$ & · & $\cdots$ \\
\hline I4 & $\ldots$ & 4 & 4 & . & 3 & i & & & 5 \\
\hline . & I & I & $\ldots$ & $\cdots$ & $\ldots$ & .. & . & & $\ldots$ \\
\hline . & $\cdots$ &. & $\cdots$ & . & $\cdots$ & . & $\cdots$ & . & $\cdots$ \\
\hline$\cdots$ & 1 & 5 & $\ddot{z}$ & .. & $\because$ & . & $\cdots$ & & . \\
\hline$\cdots$ & $\ddot{I}$ & $\because$ & $\ldots$ & " & 1 & $\ddot{I}$ & $\cdots$ & • & $\cdots$ \\
\hline
\end{tabular}




\section{TABLE II (CONTINUED)}

The figures give the number of stomachs and intestines containing the specified category of food organism for each month.

I937

Number of fish containing

recognizable food

Hydrobia ulvae

Carcinus maenas

Eupagurus bernhardus

Crangon vulgaris

Decapod larvae

Schistomysis ornata

Neomysis vulgaris

Mysid fragments

Pariambus typicus

Caprellid fragments

Gammarus locusta and

Gammarus sp.

Corophium volutator

Amphipod fragments

Copepod fragments

Crustacean fragments

Spirographis spallanzani

Cirratulid fragments

Polydora $\mathrm{sp}$.

Polychaete fragments

Oligochaeta indet.

Gonothyrea loveni

Hydroid remains

"Spawn"

Vegetable matter

Note. The "Occurrence" basis of presentation of food analyses is less suited to the dab than to other estuarine fishes. Fishes which had been eating crustaceans were rarely so distended with food as those which had taken Spirographis. For the sake of uniformity, the occurrence basis has been used, but it should be noted that this table and Fig. I I do not sufficiently emphasize the importance of Spirographis spallanzani as a food of the dab.

\section{Other Organisms*}

Ascidian fragments I (X). Ophiuroid fragments I (X), I (XI).

Polyzoan fragments $I(X I I)$. Cephalopod indet. I (VII).

Pulmonate mollusc (? Arion sp.) I $(X)$. Littorina rudis $I(V)$.

Cardium edule I (II), I (VIII), I (X). Mytilus edulis I (IV).

Chlamys opercularis and Chlamys sp. I (VII), I (VII).

Molluscs (fragments of shell) 3 (VII), I (VI), I (IX).

Dipteran larvae $I(I I I), I(I V)$. Arachnida, Araneid indet. I (III).

Cancer pagurus 2 (II). Praunus flexuosus I (VIII), I (XII).

Caprella aequilibra 5 (IX). Apherusa sp. I (VII).

Sphaeroma sp. I (XII), I (VIII), I (XI).

Gnathiid larvae $I$ (II), I (III). Pseudocuma cercaria I (III)

Cumacean fragments 3 (VI). Cyprids of Balanus sp. $3(V I I I), I(X)$.

Pseudocalanus elongatus $9(\mathrm{X})$. Ostracoda indet. $I(X I I)$.

Amphitrite sp. I (VII). Ampharete grubei 2 (VIII).

Melinna palmata I (VI). Ampharetid fragments I (VI).

Capitellid fragments I (II). Spionid fragments $I$ (III), I (II), I (XII).

Nephthys hombergi $I$ (VII), 2 (XII). Nereis cultrifera $I(V)$.

Nereis diversicolor 2 (VI).

* Figures in italics are for 1936: those in ordinary type for 1937. 
$49 \%$ of the November fish contained food, but in the following month $75 \%$ had fed. In December $193584 \%$ of the fish opened showed traces of food; in January 1936 , only $50 \%$. The fast appears to end earlier than that of the flounder.
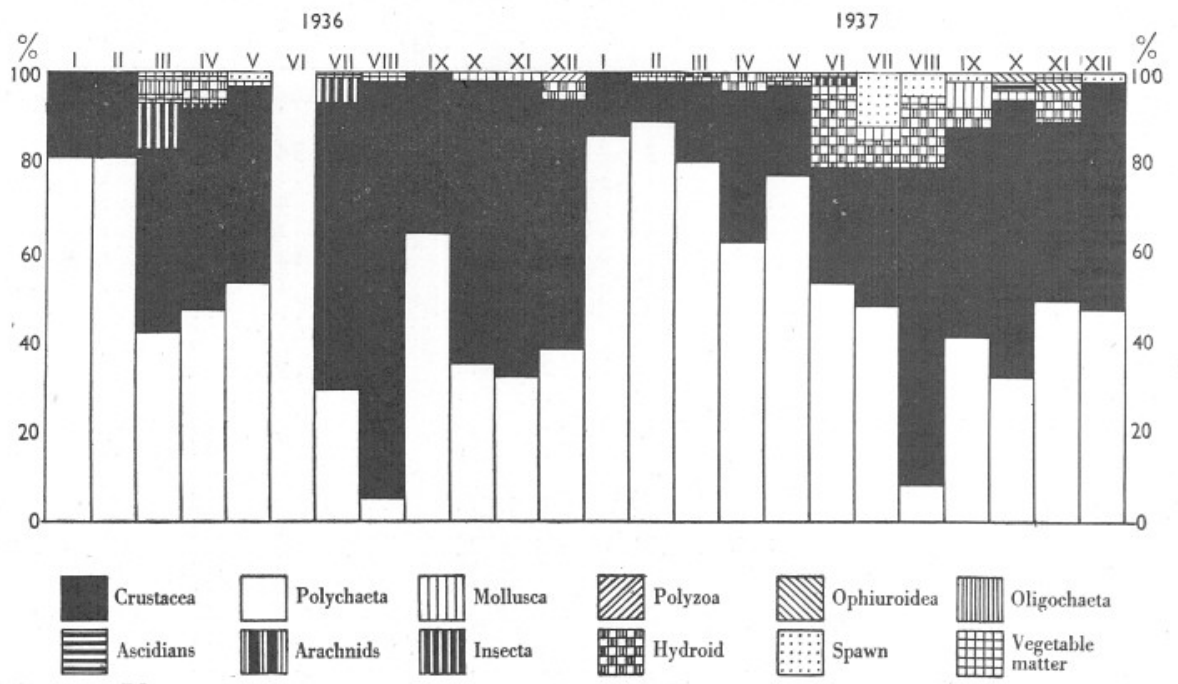

Fig. I2. Pleuronectes limanda; monthly variations in diet. (No figures are given for months in which less than 25 fish were examined.)

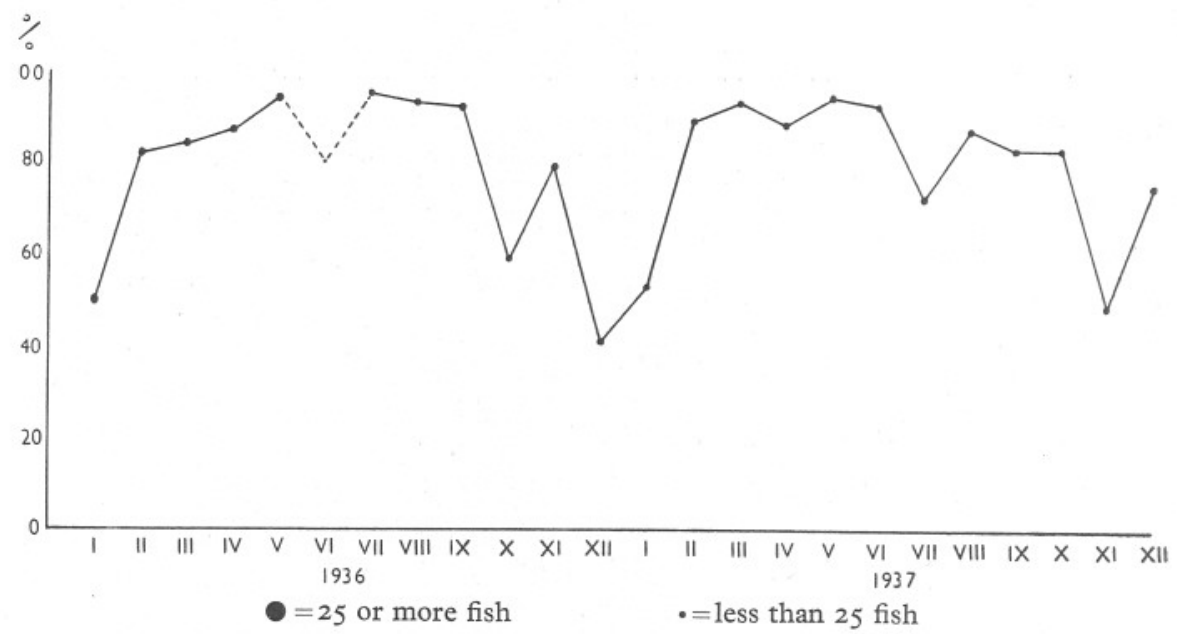

Fig. I3. Pleuronectes limanda; monthly percentages of fish which contained food.

The dab occupies a special place in the ecological relationships of the estuarine fishes. During its first growth period it competes directly with other carnivorous species, but in its second year of life it relies on food organisms which are not largely taken by any other fish. 


\section{Pleuronectes platessa L., the Plaice}

The estuaries are a nursery ground for many plaice during the first year or two of their lives: the young fish travel some distance up the rivers, being regularly caught at Sheviock Wood and in the mouth of the Tavy, where they must endure considerable changes in osmotic pressure with the ebb and flow of the tides. At Sheviock Wood on September 2I, I937, the salinity I ft. below the surface decreased from $25 \% 2 \mathrm{hr}$. before low water to $14 \%$ at low tide. Von Buddenbrock (I936) found that plaice were capable of enduring salinities as low as $10 \%$, but that below that limit their powers of osmotic regulation broke down. The young fish at Sheviock were, therefore, living in water of a salinity near the lower limit of toleration of their species, suggesting that salinity is, as would be expected, the factor which limits the upstream migration of young plaice. Maturing fish are rare in the estuaries; the "run" to the sea takes place under some other urge than that of reproduction.

In most tuck-net catches the large majority of the plaice are under $25 \mathrm{~cm}$. in length, with an occasional big fish up to $40 \mathrm{~cm}$. long. Only very extensive marking experiments would show whether these fish have wandered in from the sea, as the fishermen believe, or had remained for several years in brackish water.

\section{Growth and Period of Estuarine Life.}

The length-frequency distributions of the plaice examined during the investigation are not here reproduced. During the winter of 1935-6 fish of 6-I $7 \mathrm{~cm}$. were caught; in February 1936 there came a sudden reduction in the proportion of the larger of these fish so that the average size of the plaice in the catches decreased. In May a new length-group appeared, of small fish 2-4 cm. long. At the same time the fish of the length-group which had been caught between February and April (the smaller fish of the population of the previous winter) were caught less frequently. During the summer of 1936 the recruiting stock dominated the catches, but in September larger fish became numerous once more. The length-frequency distribution in the winter of I936-7 was essentially similar to that of the previous year, and in February I937 the sudden reduction of the proportion of larger fish was repeated. The recruitment of 1937 was much smaller than that of 1936 and was not clearly seen until July. In September the larger fish became numerous again, and in the winter the widely dispersed length distribution was found once more. In the winter of 1937, a year of small recruitment, there was a higher proportion of the larger fish than in the winter populations of the two previous years.

The general similarity of these changes in length-frequency distribution to those shown by the dab will at once be remarked. It is probable that they tell a similar story of two years of estuarine life with a descent to the sea at the end of the second year. The main difference from the dab is in the virtual absence 
of I-group fish from the catches in the summer months. There are two possible explanations of this. One is that I-group plaice, possessing considerable powers of osmotic resistance, ascend in summer to the creeks and upper tidal reaches. The other explanation is that most of the estuarine plaice go down to the sea when some I2 months old, and return at the age of I6 months, only to descend once more at the end of their second year. The first explanation seems to be the more probable, for in the "old days" big plaice used to be taken in the salmon seines working in the upper parts of the estuary in summer. The mesh of a salmon net would allow all but the largest of the estuarine plaice to escape. Such an up-river movement would be similar to that made by flounders at the same season.

The results obtained from the measurement of plaice do not permit much accurate estimation of their growth during the period of estuarine life. In 1936 the O-group was distinct from fish which may have belonged to the I-group for only three months. In May, the arithmetic mean length of the O-group was $3.5 \mathrm{~cm}$., in June $4.5 \mathrm{~cm}$. (this was a sample of only nine fish, caught on June 6,1936 ), and in the middle of July $7 \cdot 1 \mathrm{~cm}$.; during the summer months the growth of the recruiting stock appears, therefore, to be very rapid. In August a "small" group was present, but there were fish in it of lengths up to I3 $\mathrm{cm}$., which may have been members of the I-group. In 1937, the O-group was clearly defined only in July: the fish had a mean length of $5.8 \mathrm{~cm}$., that is, they were $\mathrm{I} \cdot 3 \mathrm{~cm}$. shorter than the recruiting stock in the same month of the previous year.

Some indication of the size of the estuarine plaice at the end of the first year may be obtained, if it be assumed that the O-group fish will dominate the population after the run to the sea of the I-group at the end of January. In February 1936 the mean length of the fish remaining in the estuary was $9.0 \mathrm{~cm}$.; in February 1937 it was $8.5 \mathrm{~cm}$. A few individuals of the I-group may still be in the rivers, and allowance must be made for them. The rough approximation may be made that the estuarine plaice do not reach a length of more than $8 \mathrm{~cm}$. in their first year. Since a length of $6-7 \mathrm{~cm}$. is reached in July of the first summer, there must be a great slowing down of growth during the winter fast.

In the autumn of 1937, the otoliths of all plaice were examined. It proved to be impossible to read a large proportion of them $(33 \%$ in November, 61 \% in December) with certainty. Otoliths showing only one summer zone were so uncommon in this year of small recruitment, that no deductions could be made from them. Arithmetic mean lengths of age-groups, as determined by the number of summer zones, were:

$\begin{array}{lcc} & \begin{array}{c}\text { I-group } \\ \text { 2 summer zones }\end{array} & \begin{array}{c}\text { II-group } \\ \text { 3 summer zones }\end{array} \\ \text { Oct. } & \text { I9. } & \mathrm{cm} . \\ \text { Nov. } & \text { I6.0 } & 24.83 \\ \text { Dec. } & \text { I3.5 } & 22.5 \\ & & 17.5\end{array}$


The presence of 3 -zone fish suggests that, as in the dab, a few plaice spend three growth periods in brackish water, instead of the more usual two. The reduction in the mean length of both year-groups in successive months is puzzling; the histograms for this period show a reduction in the numbers of bigger fish to have taken place by the end of October. It may be that the larger members of each year-group go down to the sea first, but it must be admitted that there is no independent evidence for this view. As a generalization it may be said that the estuarine plaice have a mean length of about $16 \mathrm{~cm}$. at the end of their second growth period. This was the length of the two-yearold fish used for feeding experiments at Plymouth by Dawes (I930).

\section{Feeding Habits.}

In the estuaries the plaice feeds largely on polychaetes and crustaceans (Table III and Fig. I4). It takes more molluscs than most of the fish living on the same grounds, but this food is of less importance than in most localities. Small plaice take more crustaceans than polychaetes, large fish more polychaetes; but the change of diet is less striking than in the dab, and crustaceans remain a more important food of big fish.

\section{Table III. Pleuronectes Platessa: Monthly Occurrence of Food Organisms.}

The figures give the number of stomachs and intestines containing the specified category of food organism for each month.

\begin{tabular}{|c|c|c|c|c|c|c|c|c|c|c|c|c|}
\hline \multirow{3}{*}{$\begin{array}{l}\text { Number of fish containing } \\
\text { recognizable food }\end{array}$} & \multicolumn{12}{|c|}{ I936 } \\
\hline & Jan. & Feb. & Mar. & Apr. & May & June & July & Aug. & Sept. & Oct. & Nov. & Dec. \\
\hline & 22 & 28 & 37 & 5 & 33 & 9 & 44 & 35 & 38 & 23 & 25 & I6 \\
\hline Paphia pullastra & . & . & 7 & $\cdots$ & 2 & 2 & $\cdots$ & . & .. & $\cdots$ & $\cdots$ & I \\
\hline Cardium edule & . & . & . & . & I & . & 3 & 2 & $\cdots$ & I & $\cdots$ & . \\
\hline Lamellibranch remains & $\cdots$ & . & I & . & I & . & 2 & I & I & . & I & . \\
\hline Crangon vulgaris & . & $\cdots$ & $\cdots$ & . & $\cdots$ & $\because$ & 5 & I & I & 2 & 2 & $\cdots$ \\
\hline Schistomysis ornata & $\cdots$ & I & 3 & . & $\cdots$ & 2 & 5 & 5 & $\cdots$ & 3 & I & 4 \\
\hline Neomysis vulgaris & . & I & $\cdots$ & $\cdots$ & $\cdots$ & . & 20 & I & I & 6 & 2 & . \\
\hline Mysidacean fragments & $\cdots$ & I & I & I & 3 & 3 & I8 & 4 & 3 & 3 & 3 & I \\
\hline Corophium volutator & 2 & 5 & I5 & 2 & 2 & . & 6 & 2 & I & 3 & I & I \\
\hline Gammarus sp. & I & $\cdots$ & I & $\ldots$ & I & $\cdots$ & $\cdots$ & $\cdots$ & $\cdots$ & $\cdots$ & $\cdots$ & $\cdots$ \\
\hline Amphipod fragments & I & 2 & 3 & . & 2 & $\cdots$ & $\cdots$ & $\cdots$ & $\cdots$ & 2 & 7 & 2 \\
\hline Copepod fragments & $\cdots$ & $\cdots$ & $\therefore$ & . & I8 & I & I & $\dot{x}$ & $\cdots$ & $\ddot{6}$ & $\ddot{8}$ & $\cdots$ \\
\hline Crustacean fragments & 2 & 3 & I4 & I & 5 & 5 & 30 & IO & 7 & 6 & 8 & $\cdots$ \\
\hline Spirographis spallanzani & $\cdots$ & 7 & 3 & I & I & $\cdots$ & $\cdots$ & $\cdots$ & 8 & 4 & 2 & . \\
\hline Ampharete grubei & $\cdots$ & $\cdots$ & $\cdots$ & $\cdots$ & $\cdots$ & $\cdots$ & 3 & 12 & $\cdots$ & $\cdots$ & $\cdots$ & $\because$ \\
\hline Melinna palmata & $\cdots$ & $\cdots$ & $\cdots$ & $\cdots$ & $\cdots$ & $\cdots$ & I. & 6 & $\cdots$ & I & $\cdots$ & I \\
\hline Ampharetid remains & $\ddot{x}$ & 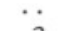 & $\cdots$ & $\because$ & $\cdots$ & $\cdots$ & . & 2 & . & 3 & $\ldots$ & $\cdots$ \\
\hline Cirratulids indet. ${ }^{\star}$ & I & 2 & 9 & 3 & . & $\cdots$ & 5 & I2 & 2 & $\cdots$ & 2 & 3 \\
\hline Polydora ciliata & 5 & 6 & 2 & $\cdots$ & $\cdots$ & $\cdots$ & $\cdots$ & $\cdots$ & $\cdots$ & . & $\cdots$ & . \\
\hline Polydora hoplura & 2 & 2 & $\cdots$ & $\cdots$ & I & $\cdots$ & $\cdots$ & $\cdots$ & 2 & $\cdots$ & 2 & . \\
\hline Polydora sp. & 3 & 7 & 3 & $\cdots$ & $\cdots$ & $\cdots$ & 4 & $\cdots$ & $\cdots$ & I & 2 & $\cdots$ \\
\hline Spionids indet. & 6 & 7 & 3 & I & 3 & I & 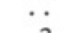 & $\cdots$ & $\because$ & $\cdots$ & . & $\cdots$ \\
\hline Nephthys hombergi & 2 & 4 & I3 & $\cdots$ & 5 & I & 3 & $\cdots$ & I & $\cdots$ & I & $\cdots$ \\
\hline Nereis diversicolor & $\cdots$ & $\cdots$ & 4 & $\cdots$ & 3 & 2 & 2 & $\cdots$ & I & $\cdots$ & . & I \\
\hline Eulalia viridis & . & I & $\cdots$ & $\cdots$ & I & $\cdots$ & $\cdots$ & $\cdots$ & . & * & $\cdots$ & . \\
\hline Phyllodoce sp. & I & I & $\ddot{x}$ & $\cdots$ & $\cdots$ & $\cdots$ & 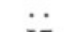 & 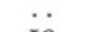 & . & $\cdots$ & I & $\cdots$ \\
\hline Polychaete remains & 22 & 9 & I7 & 3 & I4 & 2 & I7 & I9 & I5 & 9 & IO & IO \\
\hline
\end{tabular}




\section{TABLE III (CONTINUED)}

The figures give the number of stomachs and intestines containing the specified category of food organism for each month.

1937

Number of fish containing recognizable food Paphia pullastra Cardium edule

Lamellibranch remains Crangon vulgaris Schistomysis ornata

Neomysis vulgaris Mysidacean fragments Corophium volutator Gammarus sp.

Amphipod fragments Copepod fragments Crustacean fragments Spirographis spallanzani Ampharete grubei Melinna palmata Ampharetid remains Cirratulids indet.* Polydora ciliata Polydora hoplura Polydora sp.

Spionids indet. Nephthys hombergi

Nereis diversicolor

Eulalia viridis

Phyllodoce sp.

Polychaete remains

\begin{tabular}{|c|c|c|c|c|c|c|c|c|c|c|c|}
\hline \multicolumn{12}{|c|}{1937} \\
\hline Jan. & Feb. & Mar. & Apr. & May & June & July & Aug. & Sept. & Oct. & Nov. & Dec. \\
\hline 20 & 40 & 39 & IO & 32 & 20 & 38 & 28 & 29 & 24 & 28 & 30 \\
\hline$\ldots$ & $\therefore$ & 2 & $\ldots$ & 3 & $\ldots$ & $I$ & I & $\therefore$ &. & .. & .. \\
\hline . & I & I & $\ldots$ & $\ldots$ & $\ldots$ & 6 & 4 & 2 & I & . & .. \\
\hline . & .. & 2 & I & I & 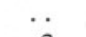 & 2 & I & I & . & $\cdots$ & $\ldots$ \\
\hline . & . & .. & .. & 7 & 2 & 5 & I & 2 & I & I & .. \\
\hline 2 & I & $\ldots$ & $\ldots$ & 3 & .. & 2 & I & I & . & $\ldots$ & $\ldots$ \\
\hline 2 & I & 4 & $\ldots$ &. & .. & I & I & IO & I & .. & $\ldots$ \\
\hline I & . & I & $\cdots$ & 3 & $\ldots$ & I & 3 & $\cdots$ & 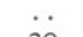 & $\because$ & $\ddot{ }$ \\
\hline I & 3 & 3 & I & . & .. & .. & .. & 2 & 20 & 19 & I2 \\
\hline * & $\because$ & 2 & $\because$ & $\because$ & . & 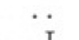 & $\because$ & $\cdots$ & $\ddot{I}$ & $\ddot{2}$ & $\because$ \\
\hline 4 & 2 & 5 & I & I & . & I & I & . & I & 2 & I \\
\hline $\begin{array}{l}\text { I } \\
6\end{array}$ & $\ddot{8}$ & $\ddot{6}$ & I & 3 & $\because 5$ & $\begin{array}{l}2 \\
5\end{array}$ & $\ddot{8}$ & $\ddot{7}$ & $\ddot{I}$ & 8 & 5 \\
\hline$\ldots$ & 4 & 3 & 2 & $\begin{array}{l}3 \\
5\end{array}$ & I &. & .. & I3 & 6 & 3 & I \\
\hline . & 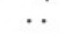 &. & $\ldots$ &. & 2 & . & . & $\because$ & . & . & . \\
\hline$\cdots$ & . & 4 & .. & 2 & I & 2 & 5 & 7 & .. & I & $\because$ \\
\hline . & 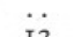 & $\because$ & $\because$ & $\cdots$ & . & . & . & I & $\because$ & 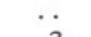 & I \\
\hline 4 & I2 & 7 & 3 & . & $\ldots$ & 4 & . & . & I & 2 & 2 \\
\hline$\cdots$ & $\because$ & $\cdots$ & $\cdots$ & $\cdots$ & $\cdots$ & . & $\cdots$ & $\cdots$ & $\because$ & $\therefore$ & $\dot{6}$ \\
\hline$\ddot{I}$ & I & $\because$ & . & 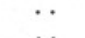 & $\cdots$ & $\ddot{I}$ & . & $\because$ & I & 2 & \\
\hline I & $\begin{array}{l}1 \\
\text { I }\end{array}$ & $\ddot{I}$ & $\begin{array}{l}\cdots \\
\ldots\end{array}$ & $\ddot{I}$ & $\because$. & $\begin{array}{l}\text { I } \\
\text { I }\end{array}$ & $\begin{array}{l}\cdots \\
\cdots\end{array}$ & $\begin{array}{l}\mathrm{I} \\
\ldots\end{array}$ & . & 3 & - \\
\hline . & 5 & I3 & 3 & 20 & 5 & 3 & 4 & 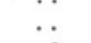 & $\cdots$ & I & $\because$ \\
\hline$\cdots$ & . & 3 & . & 4 & I & 7 & 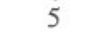 & 3 & .. & .. & ? \\
\hline . & $\cdots$ & $\ddot{I}$ & $\cdots$ & $\because$ & $\cdots$ & . & $\because$ & $\cdots$ & $\because$ & $\because$ & 3 \\
\hline io & $\ddot{23}$ & 26 & 4 & $\ddot{1} 7$ & I6 & 23 & 22 & $\ddot{4}$ & $\ddot{I}$ & $\ddot{6}$ & 9 \\
\hline
\end{tabular}

* Many of these cirratulids appeared to be Heterocirrus zetlandicus; but owing to the close similarity of juvenile Audouinia tentaculata to this species (Wilson, I936) it was felt that it would be better to list them simply as "Cirratulids".

\section{Other Organisms ${ }^{\star}$}

Gobius sp. 2 (VIII). Teleost remains $I$ (VII). Abra sp. I (IX).

Scrobicularia plana 6 (VII). Mytilus edulis I (VII).

Dipteran larvae 4 (III). Carcinus maenas I (VIII), I (VII).

Decapod larvae $I(V)$. Praunus flexuosus I $(I X)$.

Macropsis slabberi I (IX). Pariambus typicus I (IX).

Sphaeroma serratum and Sphaeroma sp. I (III), 3 (III), I (XII).

Cyathura carinata I (V). Gnathiid larvae $I(I I I)$.

Isopod fragments I (III). Temora longicornis II (V).

Eurytemora affinis II $(V)$. Oligochaete fragments 2 (III), $4(\mathrm{~V}), \mathrm{I}(\mathrm{V})$.

Sabellaria sp. I (X). Hydroid fragments I (VI), I (VII), I (XI).

"Spawn" $2(I I I), I(V)$. Diatoms 3 (VII). Vegetable matter $I(V I I I)$.

* Figures in italics are for 1936, those in ordinary type are for 1937. 


\section{Percentage of Polychaetes and Crustaceans}

$\begin{array}{ccc}\text { cm. } & \text { Polychaetes } & \text { Crustaceans } \\ 20-25 \text { and over } & 77 & 23 \\ \text { I8 } & 67 & 33 \\ \text { I6 } & 67 & 33 \\ \text { I4 } & 62 & 38 \\ \text { I2 } & 70 & 30 \\ \text { IO } & 70 & 30 \\ 8 & 59 & 4 I \\ 6 & 49 & 5 \mathrm{I} \\ 4 & 32 & 68 \\ 2 & 32 & 68\end{array}$
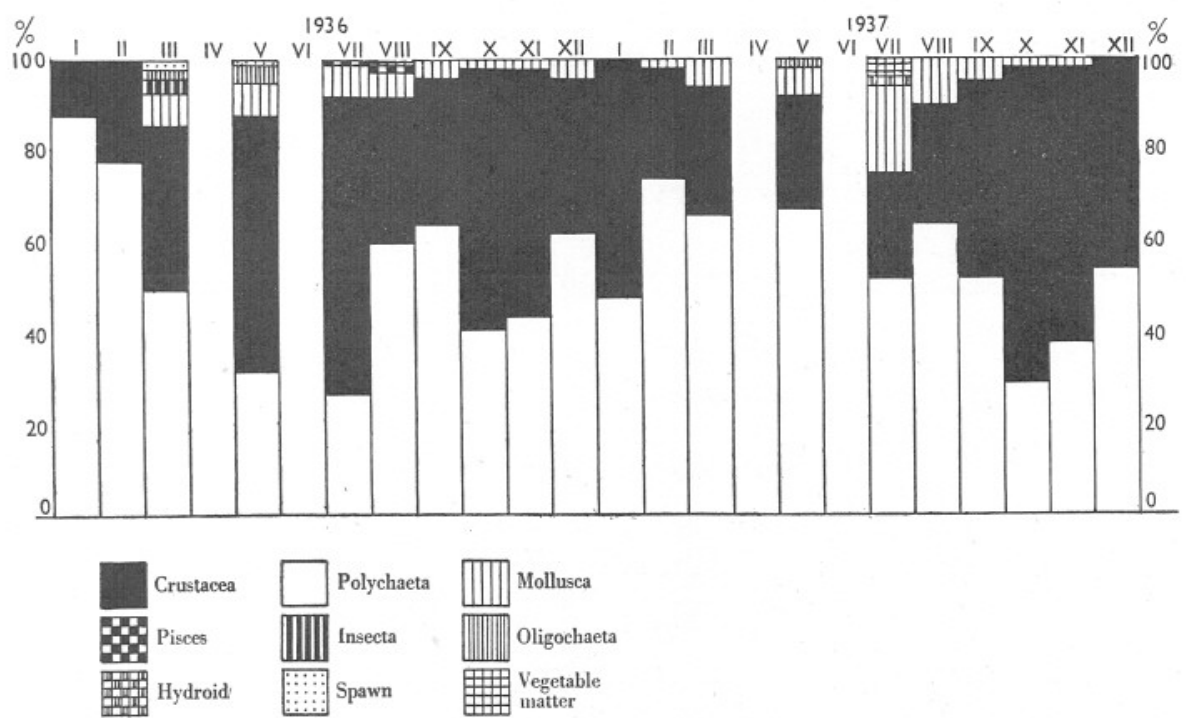

Fig. I4. Pleuronectes platessa; monthly variations in diet. (No figures are given for months in which less than 25 fish were examined.)

Scott (I895) found a decrease in consumption of crustaceans in fish over 3 in. $(7.6 \mathrm{~cm}$.) in length and Murie (1903) found that plaice in the Thames estuary took more "lob-worms" and fewer crustaceans as they grew larger. Both these authors and Todd (I9I5) found molluscs to be the most important food of the larger immature fish.

Plaice consume fewer tubicolous polychaetes than do dabs; Steven (I930) attributes this to the fact that the plaice moves horizontally towards its food, a method more suitable for the capture of free-swimming polychaetes than the tubicolous forms with their powers of swift retraction. Paphia pullastra is one of the most frequently occurring molluscan foods. The whole animal is not eaten; only the tips of the pallial siphons are neatly nipped off.

There is a winter fasting period (Fig. I5). Todd (I9I5) found that in the North Sea $100 \%$ of the plaice less than $20 \mathrm{~cm}$. in length were empty in 
November, $53 \%$ in December, and $92 \%$ in February. The largest percentage of empty stomachs in the estuaries was $72 \%$ in December 1936. In the winter of $1937-8$ the fast began very late $-67 \%$ of the fish still contained food in December 1937.

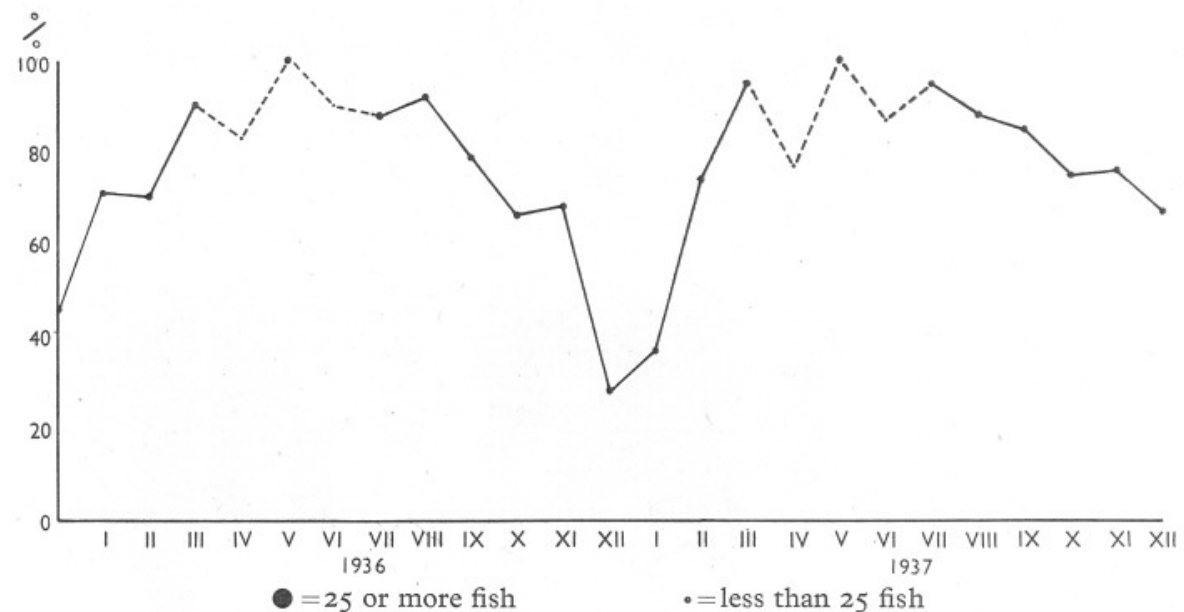

Fig. 15. Pleuronectes platessa; monthly percentages of fish which contained food,

Rhombus laevis (Rond.), the Brill

Small brill, ranging in size from 7 to $26 \mathrm{~cm}$., were caught at intervals by the tuck-net. The modal length of thirty-one fish measured between November 1935 and December 1937 was $18 \mathrm{~cm}$.; the mean length was $17.76 \mathrm{~cm}$. All were immature.

The chief food of the brill was Gobius minutus, with other small teleosts and Crangon vulgaris next in importance as shown below. In their feeding habits, brill were, therefore, outside the competition for the smaller organisms which were eaten by most of the estuarine fishes; they occupied a special place in the food relationships of the estuarine predators.

Food of Rhombus laevis

\begin{tabular}{|c|c|c|c|}
\hline & $\begin{array}{c}\text { Total } \\
\text { occurrences }\end{array}$ & & $\begin{array}{c}\text { Total } \\
\text { occurrences }\end{array}$ \\
\hline Gobius minutus & I4 & Crangon vulgaris & 8 \\
\hline Gobius sp. & 2 & Neomysis vulgaris & I \\
\hline Clupea sp. & I & Mysid fragments & 3 \\
\hline Teleost indet. & 3 & Crustacean fragments & $x$ \\
\hline
\end{tabular}

Solea vulgaris Quensel, the Sole

Immature soles were sometimes caught in the tuck-net: the largest was $19 \mathrm{~cm}$. long, the smallest $6 \mathrm{~cm}$. In the winter months, when most of the fish were taken, the length-frequency distributions showed two distinct groups: 
one 6-I2 cm. long, with an arithmetic mean length of $9.9 \mathrm{~cm}$., and the other of I $5-16 \mathrm{~cm}$., with a mean length of $15.7 \mathrm{~cm}$. Of fifty-nine soles measured between October and March, only five were in this larger group, but it is suggested that there are, in fact, fish of two year-groups living in the rivers in winter. Some of these soles were caught at Sheviock Wood. In the "old days" big soles were caught in the salmon nets in summer, but none of these fish have been seen for some years.

Food found in the stomachs of soles is shown below. In diet, the sole seems closely to resemble plaice.

\section{Solea lascaris (Risso), the Sand Sole}

In July and August I937, thirteen sand soles were taken in the rivers, ranging in size from II to $\mathrm{I} 8 \mathrm{~cm}$. Their stomach contents are shown below.

Food of Solea vulgaris and S. lascaris

$\begin{array}{lcc}\text { Lamellibranch fragments } & \begin{array}{c}\text { Solea } \\ \text { vulgaris }\end{array} & \begin{array}{c}\text { Solea } \\ \text { lascaris }\end{array} \\ \text { Carcinus maenas } & \mathrm{I} & \ldots \\ \text { Crangon vulgaris } & \mathrm{I} & \cdots \\ \text { Mysid fragments } & 6 & 8 \\ \text { Corophium volutator } & 3 & \ldots \\ \text { Crustacean fragments } & 3 & \cdots \\ \text { Polydora sp. } & 7 & \mathrm{I} \\ \text { Nereis diversicolor } & 3 & 3 \\ \text { Polychaete fragments } & 2 & 2\end{array}$

Clupea harengus L., the Herring

In the winter months hauls of adult herrings are sometimes made with the tuck-net. In January and February I936 two catches of mature fish were made, ninety-six fish on January 22 and seventy-nine on February 7. Scale readings showed that these fish belonged to the II- and III-groups:

Scale readings of adult herrings: $\mathrm{R}$. Tamar

$\begin{array}{lcc} & \text { January } & \text { February } \\ \text { I936 } & \text { I936 } \\ \text { Total catch } & 96 & 79 \\ \text { II-group fish } & 84 & 63 \\ \text { III-group fish } & \text { I2 } & \text { I6 }\end{array}$

Vertebral counts of the fish of these two samples gave the arithmetic mean numbers of vertebrae as 55.82 in January and 55.80 in February: the difference between these two means, 0.02I, is much less than the standard error of the difference, so the fish may be presumed to belong to the same "race".

None the less, there was a conspicuous difference between those in the two hauls. In the first the II-group fish had a length dispersal of $16-21 \mathrm{~cm}$., and 
a mean length of $19.4 \mathrm{~cm}$.; the mean of the III-group was $20.8 \mathrm{~cm}$. In the second haul, the mean length of the II-group fish was $20.77 \mathrm{~cm}$., with a length dispersal of $19-22 \mathrm{~cm}$., and the mean of the III-group fish was $22.5 \mathrm{~cm}$. The January shoal, therefore, consisted of smaller fish of each year-group than the February shoal. Since Ford (1933) found that between 1924 and I 928 the average length of three-zoned, three-ringed fish varied from 24.2 to $25.9 \mathrm{~cm}$., it seems that in both hauls the III-group fish were some of the smallest of their year class.

There was a marked difference in the sexual condition of the females in these two shoals. In January the mean length of the II-group females was $19.4 \mathrm{~cm}$., and only one fish out of fifty-one was spent: six of the eight IIIgroup females were virgin fish. In the February shoal, the mean length of the II-group females was $20.84 \mathrm{~cm}$.; twenty-eight out of thirty-seven fish were spent and so were all the six III-group females. In both shoals none of the II-group males, and only three out of a combined total of fifteen III-group males were spent. The contrast between the female fish of these two samples suggests that both size and sexual condition may be among the factors influencing the organization of herring shoals.

Occasional specimens of third and fourth year herring were taken on other dates.

The majority of the herrings caught in the estuaries belonged to the O-group. These young fish are, at times, extremely numerous: but the appearance of the shoals is irregular, and during the period of the investigation it was not possible consistently to sample the population. During 1927 Ford (1928 a) fished for young clupeoids in the estuaries with a fine-meshed tuck-net; he found, as has already been noted, that the practice of measuring fish to the longest caudal ray could not be followed with O-group herring on account of the battered and broken state of the tails of so many of the fish. This abrasion of the tail was observed again in 1936-7: consequently, for O-group fish only, the length used is the "body length" from the tip of the snout to the end of the scaled area of the caudal peduncle. The fish of the older year-groups do not show this reduced condition of the tail: it may be that the fin-rays are regenerated, but perhaps the fish with battered tails die off.

Between November 1935 and March 1936, the O-group herrings taken in the tuck-net belonged to a single length-group, of fish $6-10 \mathrm{~cm}$. long. Few herrings were caught during the summer of 1936, but in September of that year fish of two length-groups were caught, one of $3-5 \mathrm{~cm}$., the other of $8.5-12.5 \mathrm{~cm}$. The smaller group was not met again during the winter, but some fish of the larger group were taken until March 1937. In May I937 a new group of fish was found, $3 \cdot 5-5 \mathrm{~cm}$. long. In June the young herring were $4-7.5 \mathrm{~cm}$. in length, and by August the length distribution was $7-9.5 \mathrm{~cm}$. In September the length distribution was 9-II. $5 \mathrm{~cm}$. and by December I 937 was IO- $12.5 \mathrm{~cm}$. The most complete series of observations was made in 1937, when adequate samples of fish were obtained in May, June, August, 
September, October and December: the growth during this period was from a mean length of $4.72 \mathrm{~cm}$. in May to II.5 cm. in December. These figures correspond closely with the growth found by Ford in 1927: from a mean length of $4.76 \mathrm{~cm}$. on May 26 to one of $10.92 \mathrm{~cm}$. on December 5 .

I am told by Mr Ford that the herring population of the estuaries at any time is made up of numerous shoals, in which the length distributions of the fish vary considerably, and that the distribution of these shoals is constantly changing. In view of these facts it was thought best not to attempt to draw a series of detailed conclusions from the data collected while tuck-netting, but simply to produce summaries of measurements as evidence of the youth of the major part of the herring population.

No young herring were caught during the month of April, for the population is reduced by the departure of the I-group fish to the sea some time before the arrival of the O-group of the succeeding year class. For the herring, as for so many other species, the estuaries are a nursery ground. Most species, having once left brackish water, do not return in any strength: the herring, however, is of a different habit, for there is a second visit of part of the population (not necessarily of the individuals which were reared in the river mouths) in the autumn months. I-group herring are uncommon; some caught at West Muds on August 8 I936 were named by the fisherman "little summer herring". A few fish showing one winter zone and two summer rings were taken in 1937.

There is a drift-net fishery for herring in the river mouths from midSeptember until mid-November: light drift-nets (a typical net would be 8 fathoms long, 46 meshes to the yard and 120 meshes deep) are worked from the open tuck-boats with a crew of one or two men. The nets are shot across the tide and float before it, the thickly corked head-rope at the surface. The boat is not kept fastened to the net; the men row along the line of the floating corks, and at times lift a few feet at one end of the net to see how the fish are "striking". Each of these shots is called a "drive" and may last from Io min. to half an hour, the time varying with the area of water unobstructed by piers and buoys and with the speed of the current. Series of drives are made at dawn and dusk, and sometimes at the change of the night tide: change of light and of tide are mentioned by Graham (I93I) among the factors believed to cause a "swim" of herring in the North Sea. The fishermen find that the herring become meshed equally on both sides of the net, and from this believe that the fish, when caught, are rising directly from the bottom rather that moving up or down the harbour.

Only once did I have the opportunity of examining drift-net fish. These were eight fish of the III- and IV-groups, and were the whole catch from $3 \mathrm{hr}$. work on October 20 I936. Seven were empty, the eighth contained the remains of a small teleost. In both 1936 and 1937 bad fisheries in the rivers preceded very poor seasons for the steam and motor drifters working off Plymouth. 
Feeding Habits.

Herring in the estuaries feed almost entirely on crustaceans. The food analyses are set forth in Table IV, and call for little comment. Copepods are the most important food in winter, mysids in the summer months. Ford (I928 a) mentions mysids and copepods as the principal foods of young herring in the Tamar and Lynher. The O-group fish have no winter fast.

\section{Clupea sprattus L., the Sprat}

In the old days, sprats were caught in big seines worked by a crew of six men; but in the last few years there has been little sprat fishing in the harbour, for the shoals of well-grown fish have not been there to catch. In November I935, some sixty small sprats, $3-4.5 \mathrm{~cm}$. long were caught in the tuck-net. After that month, sprats were uncommon until August 1936: from then until September 1937, large samples of sprats were obtained in all months except October and November. In August 1936 the length-frequency distribution was from 3 to $5.5 \mathrm{~cm}$.; by December it had increased to $3.5-7.5 \mathrm{~cm}$., and by May 1937 had reached $4.5-8.5 \mathrm{~cm}$. In May 1937 a new length-group appeared, $2.5-3.5 \mathrm{~cm}$. long; by September, this group had a length-frequency distribution of $3-4.5 \mathrm{~cm}$., while the previous length-group was now $5.5-8 \mathrm{~cm}$. long. Irregularity of sampling makes it impossible to do more than make suggestions of possible interpretations of the data. It seems that one yeargroup, first met in August 1936, grew from a length of a little under $5 \mathrm{~cm}$. in that month to a length of about $7 \cdot 7 \mathrm{~cm}$. in the following June. A second length-group, presumably the succeeding year class, first appeared in May 1937, when the mean length of the fish was $3 \mathrm{~cm}$.: during the first 5 months of estuarine life they increased their length by only $0.6 \mathrm{~cm}$.

These small sprats make excellent "whitebait", but the local fishermen are unable to obtain any sale for them.

The sprat is a direct competitor with the herring for its food, in which copepods bulk largely. Stomach content analyses are shown in Table V. There was no winter fasting period.

\section{Clupea pilchardus Walb., the Pilchard}

In September 1936 I had the opportunity of measuring a sample of pilchards caught in a tuck-net at Kiln Bay. There were fifty-five fish with a length distribution from 2I to $26.5 \mathrm{~cm}$. and an arithmetic mean length of $24.3 \mathrm{~cm}$. On October 20 of the same year twenty-seven were caught in a herring driftnet off Saltash. They had a length distribution of $20-25.5 \mathrm{~cm}$., and a mean length of $23.64 \mathrm{~cm}$. The fishermen tell me that pilchards are never common in the estuaries, and that there is practically no sale for them. 


\section{TABLE IV. CLUPEA haRENGUS: MONTHLy OCCURRENCE OF Food ORganisms}

The figures give the number of fish containing the specified category of food organism in each month.

1936

Number of fish containing

recognizable food

Gobius sp.

Teleost remains

Crangon vulgaris

Decapod larvae

Neomysis vulgaris

Macropsis slabberi

Schistomysis ornata

Praunus flexuosus

Mysidacean fragments

Corophium crassicorne

Corophium volutator

Corophium sp.

Gammarus sp.

Amphipod fragments

Gnathiid larvae

Cirripede cyprids

Harpacticoid copepods

Corycaeus anglicus

Cyclopoid copepods

Eurytemora affinis

Temora longicornis

Paracalanus parvus

Calanoid copepods

Copepod nauplii

Copepod ova, spermato-

phores and fragments

Ostracoda

Crustacean fragments

Nereis diversicolor

Polychaete fragments

Jan. Feb. Mar. Apr. May June July Aug. Sept. Oct. Nov. Dec.

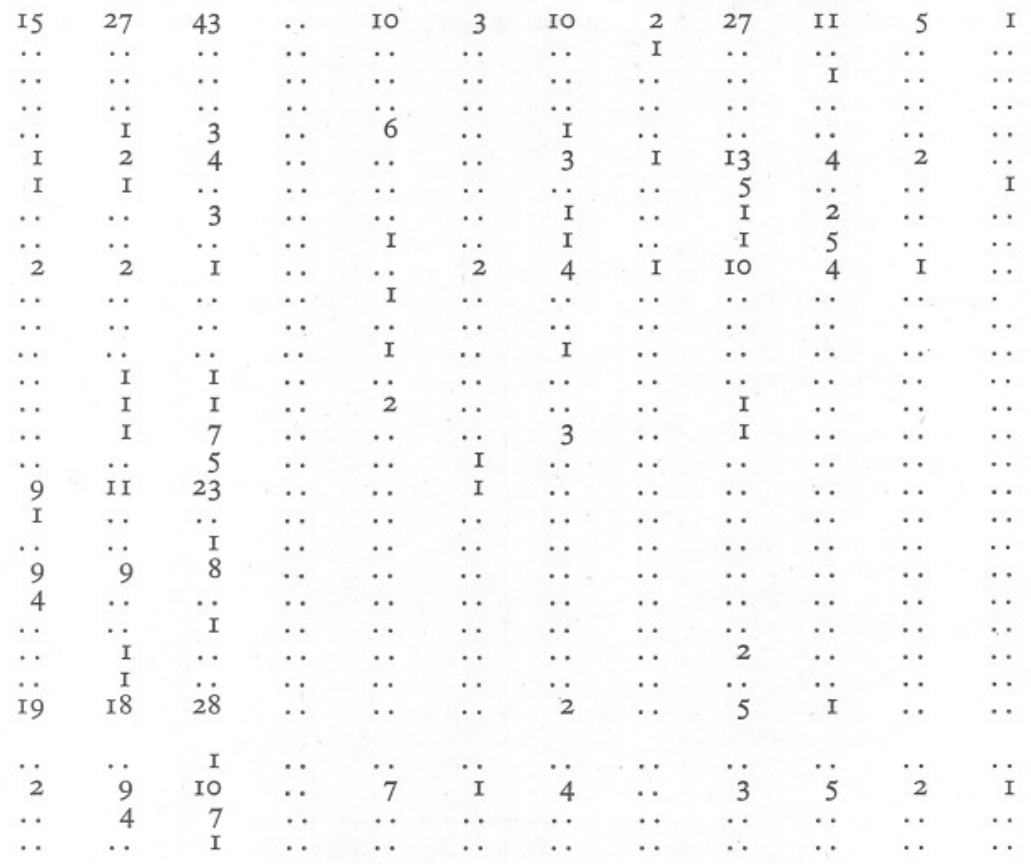

1937

Number of fish containing recognizable food

Gobius sp.

Teleost remains

Crangon vulgaris

Decapod larvae

Neomysis vulgaris

Macropsis slabberi

Schistomysis ornata

Praunus flexuosus

Mysidacean fragments

Corophium crassicorne

Corophium volutator

Corophium sp.

Gammarus sp.

Amphipod fragments

Gnathiid larvae

Cirripede cyprids

Harpacticoid copepods

Corycaeus anglicus

Cyclopoid copepods

Eurytemora affinis

Temora longicornis

Paracalanus parvus

Calanoid copepods

Copepod nauplii

Copepod ova, spermato-

phores and fragments

Ostracoda

Crustacean fragments

Nereis diversicolor

Polychaete fragments

Jan. Feb. Mar. Apr. May June July Aug. Sept. Oct. Nov. Dec.

\begin{tabular}{|c|c|c|c|c|c|c|c|c|c|c|}
\hline 7 & 7 & 4 & . & I6 & $2 \mathrm{I}$ & 2 & $\mathrm{I}_{7}$ & I4 & . & 2 \\
\hline . & . & . & $\cdots$ & $\cdots$ & . & . & .. & . & . & . \\
\hline . & . & $\ldots$ & . & I & I & I & $\because$ & . & $\cdots$ & .. \\
\hline . & . & . & . & $\cdots$ & I & . & 2 & . & . & .. \\
\hline 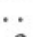 & $\cdots$ & . & . & $\cdots$ & I & . & . & . & . & .. \\
\hline 2 & 2 & I & $\ldots$ & 3 & 5 & .. & 9 & Io & $\ldots$ & .. \\
\hline . & . & 2 & $\cdots$ & $\cdots$ & . & . & .. & 9 & $\cdots$ & .. \\
\hline . & I & $\ldots$ & $\ldots$ & $\ldots$ & 4 & . & $\ldots$ & $\ldots$ & $\cdots$ & .. \\
\hline 4 & . & 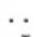 & . & $\cdots$ & 4 & . & 5 & I & . & I \\
\hline . & I & I & $\cdots$ & I & 4 & .. & 3 & 3 & $\cdots$ & 2 \\
\hline . & . & $\ldots$ & $\cdots$ & $\cdots$ & . & 2. & . & .. & $\cdots$ & .. \\
\hline . & .. & $\ldots$ & $\therefore$ & $\ldots$ & . & . & $\cdots$ & $\ldots$ & $\cdots$ & .. \\
\hline . & .. & $\cdots$ & $\cdots$ & $\cdots$ & . & .. & . & $\cdots$ & . & . \\
\hline . & .. & $\cdots$ & $\cdots$ & $\cdots$ & . & . & 4 & $\cdots$ & $\cdots$ & I \\
\hline . & . & $\ldots$ & $\ldots$ & $\ldots$ & .. & I & . & $\ldots$ & $\ldots$ & .. \\
\hline . & . & $\ldots$ & $\ldots$ & $\cdots$ & I & .. & . & $\cdots$ & . & .. \\
\hline . & . & $\cdots$ & . & 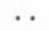 & .. & . & . & $\cdots$ & . & . \\
\hline . & . & $\cdots$ & $\cdots$ & I & 2 & . & . & $\cdots$ & . & . \\
\hline .. & .. & $\cdots$ & . & $\cdots$ & . & . & $\cdots$ & $\cdots$ & . & . \\
\hline . & . & $\cdots$ & . & $\cdots$ & .. & . & . & $\cdots$ & $\cdots$ & $\cdots$ \\
\hline . & I & $\cdots$ & $\cdots$ & 3 & . & . & . & $\cdots$ & $\cdots$ & . \\
\hline . & .. & $\cdots$ & $\cdots$ & 4 & . & . & . & . & $\cdots$ & . \\
\hline . & .. & $\cdots$ & $\cdots$ & $\because$ & $\because$ & . & . & $\cdots$ & $\cdots$ & . \\
\hline . & $\cdots$ & $\ldots$ & $\cdots$ & I & 2 & . & $\cdots$ & $\cdots$ & $\cdots$ & . \\
\hline . & $\cdots$ & $\cdots$ & $\cdots$ & $\because \%$ & . & .. & . & . & $\cdots$ & . \\
\hline$\cdots$ & $\cdots$ & $\cdots$ & . & I6 & 5 & . & $\cdots$ & $\cdots$ & $\cdots$ & . \\
\hline & . & & $\cdots$ & $\cdots$ & . & $\ldots$ & . &. & . & . \\
\hline 3 & 4 & I & .. & $\ldots$ & 7 & I & 3 & I & $\ldots$ & I \\
\hline & $\cdots$ & $\cdots$ & 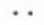 & $\cdots$ & • & .. & . & . & 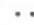 & . \\
\hline$\cdots$ & $\cdots$ & $\cdots$ & $\cdots$ & $\cdots$ & . & . & . & . & . & . \\
\hline
\end{tabular}




\section{Table V. Clupea sprattus: Monthly Occurrence of Food Organisms}

The figures give the number of fish containing the specified category of food organism in each month.

Number of fish containing recognizable food

Lamellibranch sp.

Decapod larvae

Neomysis vulgaris

Macropsis slabberi

Mysidacean fragments

Corophium volutator

Amphipod fragments

Gnathiid larvae

Cirripede cyprids

Harpacticoid copepods

Corycaeus anglicus

Cyclopoid copepoids

Acartia clausi and Acartia sp.

Eurytemora affinis

Temora longicornis

Pseudocalanus elongatus

Calanus finmarchicus

Calanoid copepods

Copepod nauplii

Copepod ova, spermato-

phores and fragments

Podon intermedius

Crustacean fragments

Polychaete fragments

Peridinium sp.

$$
\text { r936 }
$$

Jan. Feb. Mar. Apr. May June July Aug. Sept. Oct. Nov. Dec.

\begin{tabular}{|c|c|c|c|c|c|c|c|c|c|c|c|}
\hline 6 & 4 & 4 & .. & 3 & .. & .. & 9 & I9 & . & 7 & 5 \\
\hline . & .. & .. & $\ldots$ & .. & .. & $\ldots$ & .. & .. & . & $\ldots$ & $\therefore$ \\
\hline . & . & . & .. & . & .. & . & $\ldots$ & $\because$ & $\cdots$ & $\ldots$ & . \\
\hline . & . & .. & .. & .. & .. & . & .. & I & . & $\ldots$ & .. \\
\hline . & . & . & .. & . & .. & . & . & 3 & . & $\ldots$ & . \\
\hline I & .. & .. & .. & . & .. & .. & I & 4 & $\cdots$ & $\ldots$ & . \\
\hline . & . & . & .. & . & .. & . & .. & .. & $\cdots$ & $\ldots$ & . \\
\hline . & I & . & .. & . & .. & .. & .. & . & . & $\ldots$ & . \\
\hline . & . & . & .. & .. & .. & . & .. & I & $\ldots$ & $\ldots$ & . \\
\hline$?$ & $\because$ & $\because$ & . & . & . & . & $\because$ & . & $\cdots$ & $\cdots$ & 6 \\
\hline 3 & 3 & 2 & . & 3 & . & . & I & .. & $\cdots$ & $\cdots$ & 6 \\
\hline . & . & . & . & .. & . & . & . & $\cdots$ & $\cdots$ & $\ldots$ & .. \\
\hline . & . & . & . & . & .. & . & $\because$ & $\because$ & $\cdots$ & $\cdots$ & .. \\
\hline . & .. & $\ldots$ & . & I & . & .. & 2 & I & $\cdots$ & $\cdots$ & . \\
\hline 5 & 3 & 2 & .. & $\ldots$ & .. & .. & .. & 3 & $\ldots$ & $\ldots$ & 6 \\
\hline 5 & .. & $\cdots$ & .. & 2 & .. & . & .. & I & $\cdots$ & $\ldots$ & I \\
\hline .. & .. & $\ldots$ & .. & $\ldots$ & .. & . & .. & $\because$ & . & $\ldots$ & . \\
\hline . & .. & $\ldots$ & .. & $\ldots$ & .. & . & .. & I & $\cdots$ & $\ldots$ & 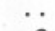 \\
\hline . & . & $\ldots$ & . & 2 & .. & $\ldots$ & 2 & Io & $\cdots$ & $\ldots$ & 2 \\
\hline 藏 & $\because$ & 6 & . & 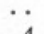 & . & - & 7 & 7 & $\cdots$ & $\cdots$ & 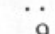 \\
\hline & & & & & & & & & & & \\
\hline . & .. & .. & .. & $\ldots$ & .. & .. & .. & . & $\ldots$ & $\ldots$ & .. \\
\hline . & I & 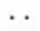 & .. & I & .. & . & .. & 5 & $\cdots$ & $\ldots$ & . \\
\hline. & .. & 2 & .. & . & .. & .. & .. & . & . & $\ldots$ & .. \\
\hline .. & .. & .. & .. & $\ldots$ & .. & .. & .. & . & $\ldots$ & $\ldots$ & . \\
\hline
\end{tabular}

Number of fish containing recognizable food

Lamellibranch sp.

Decapod larvae

Neomysis vulgaris

Macropsis slabberi

Mysidacean fragments

Corophium volutator

Amphipod fragments

Gnathiid larvae

Cirripede cyprids

Harpacticoid copepods

Corycaeus anglicus

Cyclopoid copepods

Acartia clausi and Acartia

sp.

Eurytemora affinis

Temora longicornis

Pseudocalanus elongatus

Calanus finmarchicus

Calanoid copepods

Copepod nauplii

Copepod ova, spermato-

phores and fragments

Podon intermedius

Crustacean fragments

Polychaete fragments

Peridinium sp.

Jan. Feb. Mar. Apr. May June July Aug. Sept. Oct. Nov. Dec.

\begin{tabular}{|c|c|c|c|c|c|c|c|}
\hline 24 & I & 22 & II & 32 & 5 & 3 & I2 \\
\hline $\mathrm{I}$ & . & 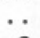 & . & 1 & $\therefore$ & . & 7 \\
\hline .. & 4 & 2 & I & I & . & . & . \\
\hline$\cdots$ & . & . & . & . & . & $\ldots$ & . \\
\hline - & $\ldots$ & . & .. & . & . & $\ldots$ & . \\
\hline . & $\ldots$ & . & $\ldots$ & . & $\cdots$ & . & . \\
\hline . & . & . & . & . & . & $\ldots$ & . \\
\hline - & $\ldots$ & . & . & . & . & . & . \\
\hline . & . & . & . & $\because$ & . & . & $\cdots$ \\
\hline 6 & 3 & 5 & $\ddot{3}$ & $\begin{array}{l}6 \\
3\end{array}$ & " & " & $\cdots$ \\
\hline . & .. & $\ldots$ & .. & . & . & .. & . \\
\hline I & I & $\because$ & . & . & . & . & . \\
\hline . & .. & I & .. & I & $\ldots$ & .. & . \\
\hline 2 & 6 & I6 & .. & 3 & I & .. & .. \\
\hline$\cdots$ & $\cdots$ & $\therefore$ & $\ldots$ & 2 & . & $\ldots$ & . \\
\hline . & 3 & 7 & . & 4 & . & $\cdots$ & $\cdots$ \\
\hline & 1 & . & $\because$ & $\because$ & - & . & $\cdots$ \\
\hline $\begin{array}{l}3 \\
2\end{array}$ & 3 & " & . & 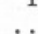 & $\because$ & $\ddot{r}$ & $\cdots$ \\
\hline $\mathrm{I}_{7}$ & 7 & I6 & I4 & 40 & 4 & 3 & 8 \\
\hline & & & & & 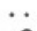 & . & . \\
\hline 2 & $\mathbf{I}$ & $\mathbf{I}$ & 1 & I & 2 & . & . \\
\hline . & . & :. & $\because$ & $\because$ & $\because$ & $\because$ & $\ddot{I}$ \\
\hline
\end{tabular}




\section{Salmo trutta L., the Sea Trout}

Small sea-trout-called "Peal" by the west countryman-were occasionally taken in the tuck-net: a few of these were killed in the cod-end, or gilled, and these were opened for stomach contents.

\begin{tabular}{|c|c|c|c|c|}
\hline $\begin{array}{l}\text { Length } \\
\mathrm{cm} .\end{array}$ & Date & Place of capture & Food & Notes \\
\hline I6.7 & 7. ii. 36 & $\begin{array}{l}\text { Pier Ground, } \\
\text { Saltash }\end{array}$ & .. & . \\
\hline 35.4 & 2I.x. 36 & Off Saltash & Clupea sp., small, 4 or 5 & $\begin{array}{l}\text { Gilled in a herring } \\
\text { drift-net, set near } \\
\text { the surface }\end{array}$ \\
\hline $17 \cdot 7$ & 8. xii. 37 & Saltash & $\begin{array}{l}\text { Clupea sprattus, } 6 \mathrm{~cm} ., \\
\text { I; Clupea sp. } 8 \mathrm{~cm} ., \text { I }\end{array}$ & . \\
\hline $38 \cdot 5$ & I7. xii. 37 & Sheviock Wood & $\begin{array}{l}\text { Clupea sp., ca. Io cm., } \\
\text { I; Crangon vulgaris, I }\end{array}$ & $\begin{array}{l}\text { ㅇ Kelt: weight } \\
437 \text { g. }\end{array}$ \\
\hline $22 \cdot 0$ & I7. xii. 37 & Sheviock Wood & Gobius minutus, 3 of $c a$. & Imm. \\
\hline 17.5 & I7. xii. 37 & Sheviock Wood & $\begin{array}{l}\text { Gobius minutus, } 6 \mathrm{~cm} \text {., I; } \\
\text { small Teleost, I; Cran- } \\
\text { gon vulgaris, I }\end{array}$ & 이 Imm. \\
\hline
\end{tabular}

O'Donoghue \& Boyd (I930) found that sea-trout caught in Scottish waters fed much in marine conditions off the river mouths, and less in the upper estuaries and in fresh water; they found that a large proportion of fish was eaten, especially clupeoids and Ammodytes. * Nall (I930), after a survey of the food of the sea-trout in salt water, wrote: "The inference, therefore, is that where herring and sprats are present, the Sea-trout prefer them to other forms of food."

It is curious that no sea-trout smolts were seen during the run to the sea in the early summer, for the Tavy is a famous sea-trout water. The slower Tamar does not rank so high as a sporting river for these fish (Nall, I930).

\section{Salmo salar L., the Salmon}

Salmon pass through the estuaries on their way to the fresh waters of the Tamar and Lynher. The "run" begins at the end of February.

\section{Anguilla vulgaris Turton, the Eel}

Eels from 40 to $60 \mathrm{~cm}$. in length were sometimes taken in the tuck-net. They fed upon crustaceans, especially Carcinus maenas. Many small eels, Io-20 cm. long, lived under stones at Neal Point and Henn Point.

\section{Syngnathus acus L., the Pipe-fish}

Occasional specimens of the pipe-fish were netted: most of them were brought in alive to the laboratory aquarium. A pipe-fish of $40.4 \mathrm{~cm}$. on August I3 I937 contained fragments of Neomysis vulgaris.

* No trace of Ammodytes was found in any fish caught in the estuaries, nor were living sand-eels seen or captured. 


\section{Atherina presbyter Jenyns, the Smelt}

In late October I936 a Saltash fisherman showed me nine smelts which had been caught in a sprat seine on West Mud; their length distribution was:

$\begin{array}{lrrrrr}\text { Length, cm. } & \text { I2 } & \text { I3 } & \text { I4 } & \text { I5 } & \text { I6 } \\ \text { Number } & \text { I } & 2 & 3 & 2 & \text { I }\end{array}$

Three fish of $17.5,17 \cdot 0$ and $15.8 \mathrm{~cm}$. were taken at West Mud on June 25 I937; all had empty stomachs.

These were the only smelts seen during the investigation. In the "old days", smelts were so numerous that some of the Saltash men made a living by fishing for them; now the capture of half a dozen excites comment among the estuarine fishermen.

\section{Mugil chelo Cuv. and Mugil auratus Risso, the Grey Mullets}

Grey mullet are common in the Tamar and Lynher, but very difficult to catch. The fishermen say that mullet are the most cunning fish in the rivers, and that they lie among stones, or in depressions in the mud, and allow a net to be dragged over them. Even if a shoal be enclosed, and the foot-rope of the net be lying on smooth mud, the capture of the fish is not certain, for they will leap over the head-rope and so escape: on May 29 I937, about twenty fish from one shoal jumped out of the net, and only five were landed. The number of fish obtained was too small to allow any study of growth rates. Of the ten fish examined, nine were Mugil chelo, the largest $27.8 \mathrm{~cm}$. long, the smallest $9.8 \mathrm{~cm}$.: the tenth was Mugil auratus, of $16.8 \mathrm{~cm}$. The gut was always found to be full of dark, grey-green mud, containing finely divided plant remains. I am told by the fishermen that at high spring tides mullet move up to the saltings and browse on the "sedge-weed" (Obione) growing on the edges of the creeks.

In the warm, summer weather, shoals of mullet swim in the shallows along the edge of the mudflats, moving so close to the surface that their progress may be traced by the rippling of the water above them; this rippling the fishermen call "reaming". About 2.0 a.m. on October 7 I937 the grey mullet at West Muds were observed to be jumping wildly: a fish $20 \mathrm{~cm}$. long would leap a foot or more into the air and fall into the water a yard away. I was told that this nocturnal jumping was not unusual; Patterson (I904 $b$ ) records an instance of it on Breydon Water.

\section{GADIDAE}

The gadoids were the outstanding example of the type of estuarine fishes which were, by reason of the irregularity of their occurrence, difficult to study in detail. Five species were taken in the estuaries: Gadus merlangus was the 
most numerous, except during the winter of $1936-7$, when G. luscus outnumbered it as shown below:

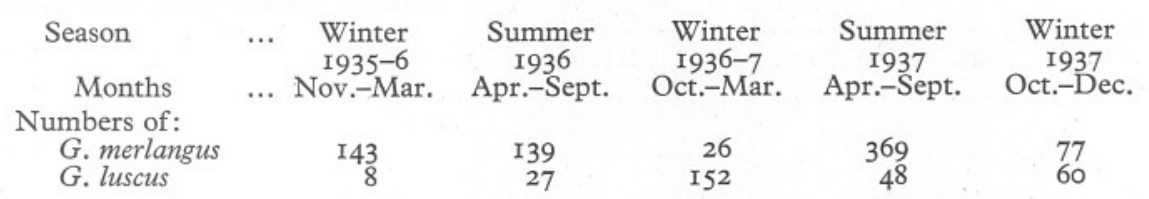

G. pollachius was caught regularly, in small numbers; G. morrhua was occasionally, G. minutus very rarely, found in the catches.

Gadus merlangus L., the Whiting

The length-frequency distributions of the whiting caught in the estuaries always showed a single, unimodal curve, suggesting that a single age-group was being dealt with in each month. The length-frequency histograms are not here reproduced; the length distributions, and arithmetic mean lengths are given in Table VI.

The appearance of a small group in the summer months, with rapid growth during the autumn and winter, and a disappearance of the stock in spring, suggests a single year of estuarine life. The recruitment in 1936 and the stock of whiting in the winter of $1936-7$ were both small; the young fish grew from a mean length of $8.0 \mathrm{~cm}$. in May to one of $12.05 \mathrm{~cm}$. in August; in the

\section{TABle VI. GadUs merlangus: Monthly Length Distribution}

\begin{tabular}{|c|c|c|c|c|c|c|c|c|c|c|c|c|c|c|}
\hline \multirow{2}{*}{$\begin{array}{l}\text { Length } \\
\text { in } \mathrm{cm} .\end{array}$} & \multicolumn{2}{|c|}{ I935 } & \multicolumn{12}{|c|}{$193^{6}$} \\
\hline & $\overparen{\text { Nov. }}$ & $\overrightarrow{\text { Dec. }}$ & Jan. & Feb. & Mar. & Apr. & May & June & July & Aug. & Sept. & Oct. & Nov. & Dec. \\
\hline 3 & .. & $\ldots$ & $\ldots$ & $\ldots$ & $\ldots$ & .. & . & $\ldots$ & $\ldots$ & . & . & .. & $\ldots$ & .. \\
\hline 4 & $\ldots$ & $\ldots$ & $\ldots$ & $\ldots$ & $\ldots$ & .. & .. & I & $\ldots$ & $\ldots$ & .. & .. & .. & .. \\
\hline 5 & . & .. & .. & . & .. & .. & 2 & I & 4 & . & . & . & .. & .. \\
\hline 6 & .. & .. & .. & $\ldots$ & .. & .. & 7 & 2 & 4 & . & .. & $\ldots$ & $\ldots$ & $\ldots$ \\
\hline 7 & .. & .. & . & . & .. & $\ldots$ & 7 & . & 2 & $\ldots$ & $\ldots$ & $\ldots$ & $\ldots$ & . \\
\hline 8 & .. & .. & $\ldots$ & .. & .. & $\ldots$ & 4 & I & . & 3 & . & $\ldots$ & $\ldots$ & . \\
\hline 9 & .. & .. & $\ldots$ & $\ldots$ & .. & .. & 2 & .. & 4 & 3 & .. & .. & . & $\ldots$ \\
\hline Ió & $\ldots$ & $\ldots$ & $\ldots$ & $\ldots$ & $\ldots$ & $\ldots$ & 4 & .. & 4 & 12 & .. & $\ldots$ & $\ldots$ & .. \\
\hline I] & $\ldots$ & $\ldots$ & $\ldots$ & $\ldots$ & $\ldots$ & .. &.. & .. & 3 & 13 & .. & $\cdots$ & .. & .. \\
\hline I & .. & . & .. & .. & I & . & .. & .. & $\therefore$ & 18 & 3 & I & I & .. \\
\hline $\mathrm{I}$ & I & .. & . & .. & .. & .. & .. & .. & $\ldots$ & II & 2 & I & . & .. \\
\hline I4 & I & I & $\therefore$ & $\therefore$ & . & . & .. & .. & .. & 5 & 3 & I & I & $\ldots$ \\
\hline I5 & I & .. & I & .. & $\ldots$ & I & .. & .. & .. & 3 & 3 & 3 & I & 2 \\
\hline I & I & .. & 2 & 2 & 2 & .. & .. & .. & I & $\therefore$ & I & I & I & . \\
\hline I7 & 2 & I &. & 2 & . & 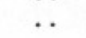 & 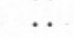 & .. & 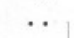 & . & .. & . & 2 & 2 \\
\hline I8 & I & I & 6 & 5 & 3 & $\cdots$ & .. & .. & 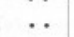 & $\cdots$ & $\ldots$ & I & I & .. \\
\hline Is & I & .. & Io & 9 & 4 & $\cdots$ & .. & .. & .. & . & $\cdots$ & . & . & $\ldots$ \\
\hline $2 c$ & 5 & 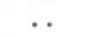 & IO & 9 & I & $\ldots$ & I & . & .. & $\ldots$ & $\ldots$ & $\cdots$ & $\cdots$ & $\ldots$ \\
\hline $2 \mathrm{I}$ & 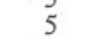 & . & 8 & 8 & 2 & 2 & .. & . & I & . & $\ldots$ & I & $\cdots$ & $\ldots$ \\
\hline 22 & IO & . & 2 & 7 & 2 & I & . & . & .. & . &. & .. & $\cdots$ & $\ldots$ \\
\hline 23 & 3 & $\cdots$ & .. & 4 & 1 & $\because$ & . & .. & .. & $\ldots$ & .. & $\ldots$ & $\cdots$ & $\ldots$ \\
\hline 24 & I & .. & 2 & I & .. & $\therefore$ & .. & .. & $\ldots$ & . & .. & $\cdot$ & $\cdots$ & $\ldots$ \\
\hline 25 & I & .. & $\ldots$ & .. & $\ldots$ & $\ldots$ & .. & .. & .. & $\ldots$ & $\ldots$ & $\ldots$ & . & $\ldots$ \\
\hline 26 & . & .. &.. & I & .. & $\ldots$ & .. & . & $\ldots$ & .. & $\ldots$ & $\ldots$ & .. & $\ldots$ \\
\hline of fish & 33 & 3 & $4 \mathrm{I}$ & 48 & I6 & 4 & 27 & 5 & 23 & 68 & I2 & 9 & 7 & 4 \\
\hline anlength & $2 \mathrm{I} \cdot \mathrm{I}$ & (I6.8) & $20 \cdot I_{4}$ & $20 \cdot 68$ & I9. I3 & $(20 \cdot 3)$ & 8.0 & $(6 \cdot 3)$ & 8.5 & 12.05 & 14.25 & $(15.85)$ & $(\mathrm{I} 6 \cdot 5)$ & (I6.5) \\
\hline
\end{tabular}




\section{TABLE VI (CONTINUED)}

\begin{tabular}{|c|c|c|c|c|c|c|c|c|c|c|c|c|}
\hline \multirow{2}{*}{$\begin{array}{l}\text { Length } \\
\text { in } \mathrm{cm} .\end{array}$} & \multicolumn{12}{|c|}{ I937 } \\
\hline & Jan. & Feb. & Mar. & Apr. & May & June & July & Aug. & Sept. & Oct. & Nov. & Dec. \\
\hline 3 & $\ldots$ & . & .. & . & . & . & .. & . & .. & . & . & .. \\
\hline 4 & . & . & . & . & . & 2 & $\ldots$ & $\ldots$ & $\ldots$ & $\ldots$ & $\ldots$ & $\ldots$ \\
\hline 5 & $\cdots$ & $\cdots$ & $\ldots$ & . & $\cdots$ & I3 & $\ldots$ & $\ldots$ & . & $\cdots$ & $\cdots$ & $\cdots$ \\
\hline 6 & . & $\cdots$ & $\ldots$ & $\ldots$ & $\cdots$ & 4I & I & $\cdots$ & $\ldots$ & $\cdots$ & $\cdots$ & .. \\
\hline 7 & . & $\ldots$ & $\ldots$ & $\ldots$ & $\ldots$ & 36 & . & $\cdots$ & $\ldots$ & $\cdots$ & $\cdots$ & $\cdots$ \\
\hline 8 & .. & $\ldots$ & $\ldots$ & $\ldots$ & $\ldots$ & 39 & 2 & $\cdots$ & $\ldots$ & . & . & I \\
\hline 9 & .. & $\ldots$ & $\ldots$ & $\ldots$ & . & 21 & 4 & $\ldots$ & . & . & . & . \\
\hline IO & $\ldots$ & $\ldots$ & $\ldots$ & $\ldots$ & $\ldots$ & I4 & II & . & 2 & $\ldots$ & .. & I \\
\hline II & $\ldots$ & $\ldots$ & $\ldots$ & $\ldots$ & $\ldots$ & I2 & 19 & I & 2 & $\cdots$ & $\ldots$ & $\ldots$ \\
\hline I2 & $\ldots$ & $\ldots$ & $\ldots$ & $\ldots$ & $\ldots$ & 6 & II & 5 & $\because$ & $\ldots$ & $\ldots$ & I \\
\hline I3 & $\ldots$ & $\ldots$ & $\ldots$ & $\ldots$ & $\ldots$ & 5 & 7 & I 8 & 6 & $\ldots$ & $\ldots$ & I \\
\hline I4 & I & $\ldots$ & $\ldots$ & . & $\ldots$ & $\ldots$ & 3 & 23 & 7 & I & I & I \\
\hline I5 & . & .. & I & $\ldots$ & $\ldots$ & $\ldots$ & 6 & I3 & 4 & $\ldots$ & 2 & .. \\
\hline 16 & .. & $\ldots$ & .. & . & $\therefore$ & $\ldots$ & I & 6 & I2 & I & 4 & I \\
\hline I7 & $\ldots$ & $\ldots$ & $\ldots$ & $\ldots$ & $\ldots$ & $\ldots$ & . & $\ldots$ & II & I & I2 & 2 \\
\hline 18 & $\ldots$ & I & $\ldots$ & $\ldots$ & $\ldots$ & $\ldots$ & $\ldots$ & $\ldots$ & 3 & 3 & II & I \\
\hline I9 & 2 & . & $\ldots$ & $\ldots$ & $\ldots$ & . & . & . & I & I & I2 & I \\
\hline 20 & I & $\ldots$ & $\ldots$ & $\ldots$ & $\ldots$ & . & $\ldots$ & $\ldots$ & I & 2 & 4 & $\ldots$ \\
\hline $2 \mathrm{I}$ & $\ldots$ & $\ldots$ & $\ldots$ & $\ldots$ & $\ldots$ & $\ldots$ & $\cdots$ & $\ldots$ & $\ldots$ & $\ldots$ & 6 & I \\
\hline 22 & $\ldots$ & $\ldots$ & $\ldots$ & $\ldots$ & $\ldots$ & $\ldots$ & $\ldots$ & $\ldots$ & $\ldots$ & I & 2 & $\ldots$ \\
\hline 23 & $\ldots$ & $\ldots$ & $\ldots$ & .. & $\ldots$ & .. & $\ldots$ & $\ldots$ & .. & . & I & I \\
\hline 24 & $\cdots$ & $\cdots$ & $\ldots$ & $\cdots$ & $\ldots$ & $\ldots$ & $\ldots$ & $\cdots$ & $\ldots$ & $\ldots$ & $\ldots$ & $\ldots$ \\
\hline 25 & . & $\ldots$ & . & . & . & . & . & . & . & $\cdots$ & $\cdots$ & . \\
\hline 26 & $\ldots$ & $\ldots$ & $\ldots$ & $\ldots$ & $\ldots$ & $\ldots$ & $\ldots$ & $\ldots$ & $\ldots$ & 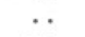 & . & $\ldots$ \\
\hline $\begin{array}{l}\text { No. of fish } \\
\text { caught }\end{array}$ & 4 & I & I & . & . & 189 & 65 & 66 & 49 & Io & 55 & I2 \\
\hline Meanlength & (I8.5 & (18.5) & $(15.5)$ & .. & . & $8 \cdot 34$ & $\mathrm{I} 2 \cdot 0$ & I 4.4 & 15.8 & I $8 \cdot 7$ & 18.9 & $16 \cdot 2$ \\
\hline
\end{tabular}

following months, the samples of fish were too small for great reliance to be placed on the results, but the fish seem to have attained a length of some $18 \mathrm{~cm}$. before the run to the sea. The O-group fish were much more numerous in the summer of 1937: they appeared in June, and grew from a mean length of $8.34 \mathrm{~cm}$. in that month to one of $18.9 \mathrm{~cm}$. in November. This very rapid growth, which was observed not only in the whiting, but also in pout and pollack, may be partly accounted for by the fact that the gadoids have no winter fasting period while in the estuaries.

Gadus luscus L., the Pout

The length-frequency distributions of the pout in each month are shown in Table VII. The irregularity of the appearance of pout in the estuaries makes it difficult to arrive at conclusions on their growth and period of estuarine life. In the autumn of 1936 , and winter of $1936-7$, when pout were numerous in some months, the length frequency distributions showed unimodal curves, suggesting that a single year group made up the population. The mean length of this group increased from $13.5 \mathrm{~cm}$. in September to $20 \mathrm{~cm}$. in January. The disappearance of this length-group before April suggests a spring run to the sea similar to that of other gadoids.

In June 1937, a number of young pout, with a mean length of $5.9 \mathrm{~cm}$., were 


\section{Table VII. Gadus luscus: Monthly Length Distribution}

\begin{tabular}{|c|c|c|c|c|c|c|c|c|c|c|c|c|c|c|}
\hline \multirow{2}{*}{$\begin{array}{l}\text { Length } \\
\text { in } \mathrm{cm} .\end{array}$} & \multicolumn{2}{|c|}{ I935 } & \multicolumn{10}{|c|}{1936} & \\
\hline & Nov. & $\overrightarrow{\text { Dec. }}$ & Jan. & Feb. & Mar. & Apr. & May & June & July & Aug. & Sept. & Oct. & Nov. & Dec. \\
\hline 3 & .. & . & .. & . & .. & . & . & . & . & .. & . & .. & .. & .. \\
\hline 4 & . & .. & . & $\ldots$ & .. & $\ldots$ & I & $\ldots$ & . & .. & .. & .. & .. & .. \\
\hline 5 & .. & .. & .. & .. & .. & . & 2 & . & $\cdots$ & .. & . & $\cdots$ & . & .. \\
\hline 6 & $\cdots$ & .. & . & $\cdots$ & . & . & $\ldots$ & . & 2 & $\cdots$ & $\cdots$ & $\cdots$ & . & . \\
\hline 7 & . & . & .. & .. & . & . & $\cdots$ & . & .. & .. & . & . & .. & . \\
\hline 8 & .. & .. & .. & . & . & .. & .. & .. & . & $\cdots$ & $\because$ & $\cdots$ & .. & . \\
\hline 9 & $\cdots$ & .. & $\ldots$ & $\ldots$ & .. & .. & .. & $\ldots$ & $\ldots$ & 3 & I & $\ldots$ & $\cdots$ & . \\
\hline Io & . & .. & $\ldots$ & $\ldots$ & $\ldots$ & $\ldots$ & .. & .. & . & I & . & $\cdots$ & .. & . \\
\hline II & $\ldots$ & .. & .. & .. & $\ldots$ & . & . & $\cdots$ & $\ldots$ & $\ldots$ & 2 & $\cdots$ & $\cdots$ & $\cdots$ \\
\hline I2 & . & .. & . & . & . & . & $\ldots$ & .. & . & .. & 6 & 2 & . & .. \\
\hline I3 & .. & .. & .. & .. & .. & .. & . & . & .. & .. & 4 & 4 & .. & $\because$ \\
\hline I4 & . & . & .. & .. & $\ldots$ & .. & .. & . & . & .. & 2 & 7 & .. & I \\
\hline I5 & $\cdots$ & .. & .. & . & $\ldots$ & .. & $\ldots$ & .. & . & . & I & I6 & .. & .. \\
\hline I6 & 2 & .. & .. & .. & $\ldots$ & . & .. & . & .. & .. & . & 27 & . & $\because$ \\
\hline I7 & .. & .. & I & .. & .. & .. & .. & .. & $\ldots$ & .. & I & 26 & . & I \\
\hline I8 & $\ldots$ & .. & .. & .. & .. & .. & .. & .. & .. & .. & I & I4 & .. & .. \\
\hline I9 & 5 & .. & $\ldots$ & $\ldots$ & $\ldots$ & . & $\ldots$ & . & .. & $\ldots$ & .. & 4 & $\cdots$ & I \\
\hline 20 & $\ldots$ & .. & $\ldots$ & $\ldots$ & $\ldots$ & .. & .. & .. & . & $\ldots$ & .. & I & .. & . \\
\hline $2 \mathrm{I}$ & $\ldots$ & .. & $\cdots$ & $\cdots$ & $\cdots$ & $\ldots$ & $\cdots$ & $\ldots$ & .. & $\ldots$ & $\ldots$ & I & . & .. \\
\hline 22 & $\ldots$ & .. & $\ldots$ & $\ldots$ & $\ldots$ & $\ldots$ & $\cdots$ & $\therefore$ & $\ldots$ & $\ldots$ & $\cdots$ & $\ldots$ & . & $\cdots$ \\
\hline 23 & . & .. & $\cdots$ & . & $\ldots$ & .. & .. & .. & .. & .. & . & .. & . & $\cdots$ \\
\hline 24 & .. & .. & .. & .. & . & .. & . & . & .. & .. & .. & .. & .. & . \\
\hline $\begin{array}{l}\text { No. of fish } \\
\text { Meanlength }\end{array}$ & 7 & . & I & . & .. & .. & 3 & . & 2 & 4 & I8 & 102 & .. & $\begin{array}{c}3 \\
(77 \cdot 2)\end{array}$ \\
\hline $\begin{array}{l}\text { Mean length } \\
\text { in } \mathrm{cm} \text {. }\end{array}$ & (18.69) & $\ldots$ & $(17 \cdot 5)$ & $\cdots$ & $\cdots$ & .. & $(5 \cdot 2)$ & .. & $(6 \cdot 5)$ & (9.75) & 13.55 & I6.75 & $\cdots$ & $17 \cdot 2)$ \\
\hline e & & & & & & I9 & 37 & & & & & & & \\
\hline
\end{tabular}

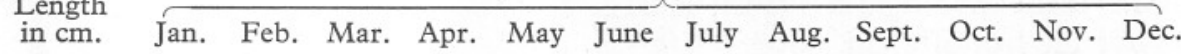

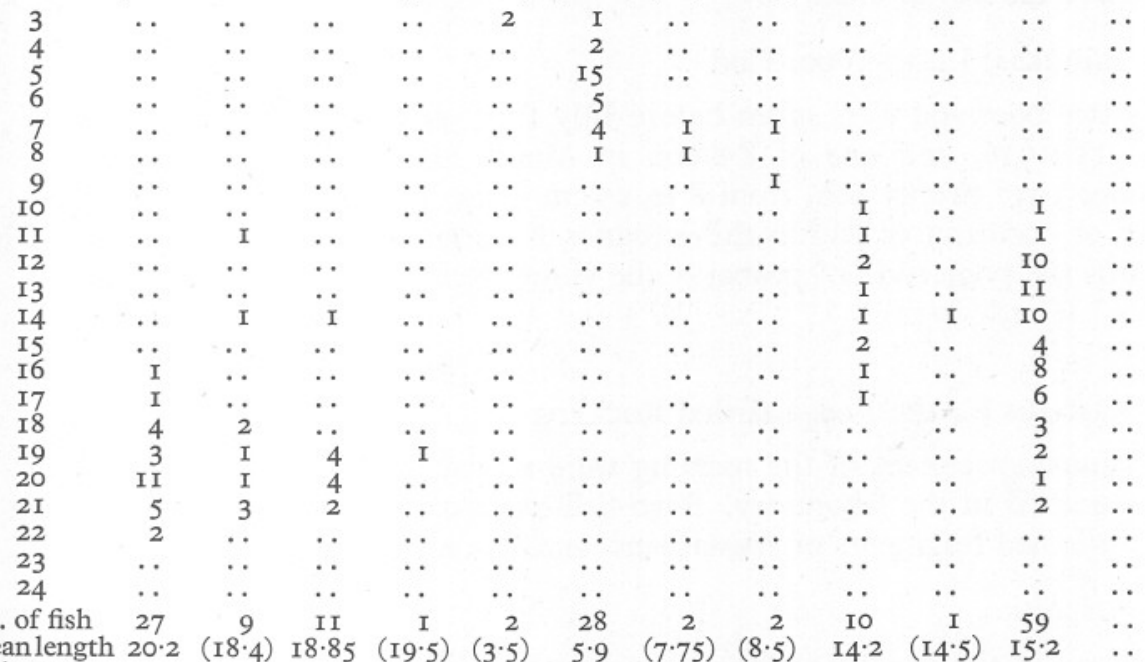
in $\mathrm{cm}$. 
caught. After that the fish were rare again until November, when fifty-nine fish caught on November 2 had a mean length of $15.2 \mathrm{~cm}$., nearly $1.5 \mathrm{~cm}$. shorter than the I02 fish caught on October 30 in the previous year.

The only conclusion that may safely be drawn is that the estuaries are, at times, a nursery ground for young pout.

Gadus pollachius L., the Pollack

Pollack were found to haunt hard ground, where the bottom was stony and weed-grown. Except for very small summer fish, large numbers of pollack were never taken-probably owing to the small areas of suitable habitat. The study of the length-frequency distributions and mean lengths (Table VIII) suggests an estuarine history similar to that of the whiting; but, owing to the scantiness of the material, any conclusions are only tentatively put forward.

Young pollack were first observed in June in each year, when they were about $6.5 \mathrm{~cm}$. long. Growth during the following autumn and winter was rapid; the length increment was about $\mathrm{I} 2 \mathrm{~cm}$. in 9 months. After a year of estuarine life most of the fish go down to the sea in spring.

As in the whiting, the recruitment of 1937 seems to have been larger than that of 1936 .

Gadus morrhua L., the Cod

Cod were never numerous-only twenty-six were examined during the 26 months of the investigation. Fish as large as $35 \mathrm{~cm}$. were twice taken, and once a juvenile fish of $6 \mathrm{~cm}$.

Gadus minutus, L., the Poor Cod

Only two poor cod were taken before July 1937 - a fish of $9.6 \mathrm{~cm}$. on September I5 1936, and one of $8.2 \mathrm{~cm}$. in March 1937. Between July and December 1937 twenty fish, from 8 to $15 \mathrm{~cm}$. long, were caught. The small number of occurrences within the estuaries is curious, for in the waters off Plymouth the poor cod is "probably the commonest gadoid on the trawling grounds" (Ford, I93I).

\section{Onos mustelus L., the Five-bearded Rockling}

Occasional specimens of the rockling were netted, but only a few of them were examined in the laboratory. Two fish of $14 \mathrm{~cm}$., opened in December 1937, contained fragments of crustaceans, and one a small goby in addition.

\section{Feeding Habits.}

The food of the gadoids during their estuarine life is shown in Table IX. Crangon vulgaris and mysids form the bulk of the food of all species, with small teleost fish next in importance. There is no winter fasting period. All the gadoids compete with one another, and with the flounder, for food. 


\section{TABle VIII. Gadus pollachiUs: Monthly Length Distribution}

\begin{tabular}{|c|c|c|c|c|c|c|c|c|c|c|c|c|c|c|}
\hline \multirow{2}{*}{$\begin{array}{l}\text { Length } \\
\text { in } \mathrm{cm} .\end{array}$} & \multicolumn{2}{|c|}{ I935 } & \multicolumn{12}{|c|}{ I936 } \\
\hline & Nov. & Dec. & Jan. & Feb. & Mar. & Apr. & May & June & July & Aug. & Sept. & Oct. & Nov. & Dec. \\
\hline I & .. & .. & $\ldots$ & .. & .. & .. & .. & .. & .. & $\ldots$ & .. & . & $\ldots$ & .. \\
\hline 2 & $\ldots$ & .. & . & . & $\ldots$ & $\ldots$ & $\ldots$ & $\ldots$ & $\ldots$ & . & .. & . & $\ldots$ & .. \\
\hline 3 & .. & .. & .. & .. & .. & .. & .. & I & . & .. & .. & . & .. & . \\
\hline 4 & $\cdots$ & .. & .. & .. & .. & .. & .. & . & . & .. & . & . & . & $\cdots$ \\
\hline 5 & . & . & .. & .. & $\ldots$ & . & $\cdots$ & ${ }^{2}$ & . & . & . & . & $\cdots$ & $\cdots$ \\
\hline 6 & .. & $\ldots$ & .. & .. & .. & .. & .. & I8 & . & .. & .. & . & . & .. \\
\hline 7 & .. & .. & .. & .. & .. & .. & .. & IO & .. & .. & .. & . & . & .. \\
\hline & . & $\ldots$ & $\cdots$ & $\ldots$ & $\ldots$ & $\ldots$ & $\ldots$ & $\cdots$ & $\cdots$ & $\cdots$ & . & . & . & .. \\
\hline 9 & . & . & . & .. & $\ldots$ & $\ldots$ & $\ldots$ & $\ldots$ & 2 & 3 & . & $\cdots$ & $\cdots$ & $\because$ \\
\hline IO & . & . & $\ldots$ & .. & . & .. & . & $\ldots$ & I & I & .. & . & $\cdots$ & I \\
\hline II & $\ldots$ & $\ldots$ & . & .. & .. & .. & .. & $\ldots$ & I & I & .. & . & .. & I \\
\hline I2 & $\ldots$ & $\ldots$ & $\ldots$ & $\ldots$ & $\ldots$ & $\ldots$ & $\ldots$ & $\ldots$ & 2 & 3 & .. & . & $\ldots$ & . \\
\hline I3 & . & $\ldots$ & $\ldots$ & .. & $\ldots$ & . & $\ldots$ & $\ldots$ & .. & I & I & $\ldots$ & I & I \\
\hline I 4 & . & $\ldots$ & .. & .. & .. & . & .. & $\ldots$ & .. & .. & . & $\cdots$ & 3 & 3 \\
\hline 15 & $\cdots$ & $\ldots$ & $\ldots$ & .. & $\cdots$ & $\ldots$ & $\ldots$ & $\ldots$ & $\ldots$ & .. & I & 4 & 3 & I \\
\hline I6 & 2 & $\ldots$ & $\ldots$ & .. & .. & . & .. & . & . & 3 & .. & 3 & 2 & I \\
\hline I7 & . & . & . & .. & . & . & . & .. & .. & . & .. & I & 3 & 2 \\
\hline 18 & I & .. & $\ldots$ & I & .. & I & .. & .. & . & .. & .. & I & I & 2 \\
\hline 19 & 3 & $\ldots$ & .. & 7 & .. & .. & $\ldots$ & .. & .. & . & .. & .. & I & 2 \\
\hline 20 & 2 & . & I & 4 & .. & . & $\ldots$ & . & . & .. & .. & I & .. & . \\
\hline $2 \mathrm{I}$ & $\ldots$ & $\ldots$ & I & 3 & . & $\ldots$ & $\ldots$ & . & . & .. & .. & .. & $\ldots$ & I \\
\hline 22 & 3 & $\therefore$ & $\ldots$ & I & . & .. & . & $\ldots$ & $\ldots$ & $\ldots$ & . & $\ldots$ & .. & 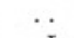 \\
\hline 23 & $\ldots$ & $\ldots$ & $\ldots$ & $\ldots$ & $\ldots$ & $\ldots$ & $\ldots$ & $\ldots$ & $\ldots$ & $\ldots$ & . & $\ldots$ & $\ldots$ & I \\
\hline 24 & $\ldots$ & . & $\ldots$ & $\ldots$ & $\ldots$ & $\ldots$ & $\ldots$ & $\ldots$ & $\ldots$ & $\ldots$ & $\ldots$ & $\cdots$ & $\cdots$ & I \\
\hline 25 & $\ldots$ & $\ldots$ & . & $\ldots$ & $\ldots$ & $\ldots$ & $\ldots$ & $\ldots$ & I & .. & $\cdots$ & . & $\cdots$ & . \\
\hline $\begin{array}{l}\text { No. of fish } \\
\text { Meanlength } \\
\text { in cm. }\end{array}$ & $\begin{array}{l}\text { II } \\
\text { I9.6 }\end{array}$ & $\begin{array}{l}. \\
.\end{array}$ & $\begin{array}{c}2 \\
(2 \mathrm{I} \cdot 0)\end{array}$ & $\begin{array}{c}16 \\
20 \cdot 25\end{array}$ & $\begin{array}{l}. \\
.\end{array}$ & $\begin{array}{c}\mathrm{I} \\
(\mathrm{I} 8 \cdot 5)\end{array}$ & $\begin{array}{l}. \\
.\end{array}$ & $\begin{array}{r}31 \\
6 \cdot 7\end{array}$ & $\left(\begin{array}{c}7 \\
(\mathrm{II} \cdot 0)\end{array}\right.$ & $\begin{array}{r}12 \\
12 \cdot 6\end{array}$ & $\begin{array}{c}2 \\
(14 \cdot 5)\end{array}$ & $\begin{array}{c}\text { Io } \\
\text { I6.8 }\end{array}$ & $\begin{array}{r}14 \\
I 6 \cdot 2\end{array}$ & $\begin{array}{c}\mathrm{I} 7 \\
\mathrm{I} 7 \cdot \mathrm{I}\end{array}$ \\
\hline 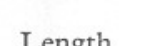 & & & & & & 9 & & & & & & & & \\
\hline
\end{tabular}

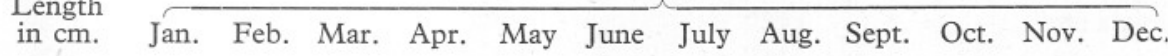

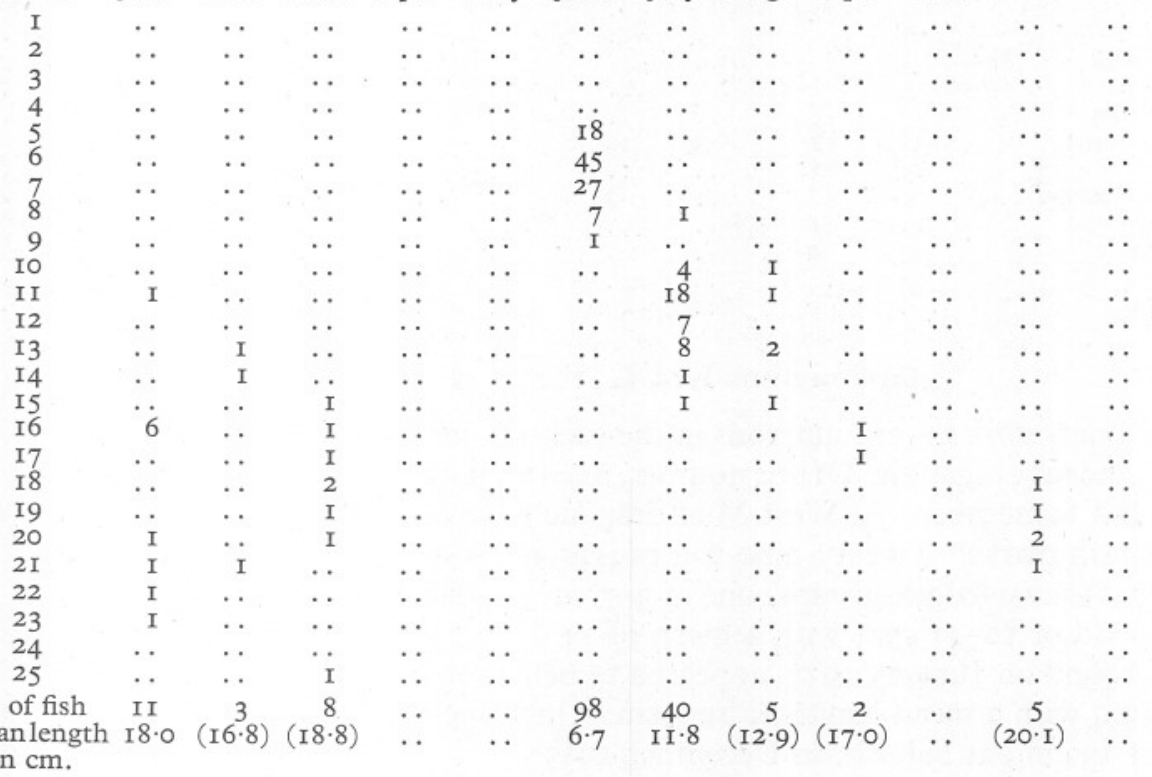




\section{Table IX. GadidaE: Occurrence of Food Organisms}

The figures give the number of fish containing the specified category of food organism.

\begin{tabular}{|c|c|c|c|c|c|c|c|c|c|c|}
\hline \multirow{3}{*}{$\begin{array}{l}\text { Number of fish containing } \\
\text { recognizable food }\end{array}$} & \multicolumn{2}{|c|}{ G. merlangus } & \multicolumn{2}{|c|}{ G. luscus } & \multicolumn{2}{|c|}{ G. pollachius } & \multicolumn{2}{|c|}{ G. morrhua } & \multicolumn{2}{|c|}{ G. minutus } \\
\hline & I936 & I937 & I936 & I937 & 1936 & I937 & I936 & I937 & 1936 & I937 \\
\hline & 158 & I97 & 57 & 82 & 87 & 76 & I6 & 5 & I & 24 \\
\hline $\begin{array}{l}\text { Gobius minutus } \\
\text { Gobius microps }\end{array}$ & I & 4 & .. & .. & 8 & 2 & .. & I & .. & \\
\hline $\begin{array}{l}\text { Gobius microps } \\
\text { Gobius sp. }\end{array}$ & $\cdots$ & $\because$ & $\cdots$ & $\because$ & .. & .. & .. & .. & .. & I \\
\hline $\begin{array}{l}\text { Gobius sp. } \\
\text { Clupea sp. }\end{array}$ & $\ddot{3}$ & $\ddot{16}$ & $\ddot{I}$ & $\begin{array}{l}2 \\
3\end{array}$ & $\ddot{q}$ & $\because$ & .. & . & .. & .. \\
\hline $\begin{array}{l}\text { Clupea sp. } \\
\text { Teleost remains }\end{array}$ & $\mathrm{I}_{3}$ & 23 & 7 & $\begin{array}{l}3 \\
1\end{array}$ & 7 & 3 & $\cdots$ & $\because$ & $\cdots$ & $\begin{array}{l}\cdots \\
\ldots\end{array}$ \\
\hline Hydrobia ulvae & $\mathrm{I}$ & . & . & $\begin{array}{l}\mathrm{I} \\
. .\end{array}$ & $\begin{array}{l}\text { I5 } \\
\ldots\end{array}$ & II & 4 & $\begin{array}{l}\mathrm{I} \\
. .\end{array}$ & $\begin{array}{l}\cdots \\
\ldots\end{array}$ & $\begin{array}{l}\cdots \\
\cdots\end{array}$ \\
\hline Gastropod fragments & . & I & .. & .. & .. & $\because$ & $\cdots$ & $\cdots$ & .. & $\because$ \\
\hline Cardium edule & . & .. & .. & I & .. & .. & .. & .. & .. & $\because$ \\
\hline Carcinus maenas & 2 & .. & 2 & 9 & .. & .. & I & . & . & 2 \\
\hline $\begin{array}{l}\text { Eupagurus bernhardus } \\
\end{array}$ & $\cdots$ & $\because$ & . & $\because$ & $\cdots$ & $\cdots$ & I & .. & .. & $\because$ \\
\hline $\begin{array}{l}\text { Leander squilla and Leander sp. } \\
\text { Crangon vulgaris }\end{array}$ & $\underset{\text { ro3 }}{\ddot{0}}$ & & $\ddot{4} \dot{8}$ & $\begin{array}{r}1 \\
55\end{array}$ & $\ddot{2}$ & $\ddot{i}$ & 5 & $\because$ & . & II \\
\hline $\begin{array}{l}\text { Crangon vulgaris } \\
\text { Decapod larvae }\end{array}$ & $\begin{array}{c}\text { I03 } \\
\ldots\end{array}$ & 125 & $\begin{array}{l}48 \\
. .\end{array}$ & $\begin{array}{r}55 \\
7\end{array}$ & 33 & $\begin{array}{l}\text { II } \\
\ldots\end{array}$ & $\begin{array}{l}\text { 10 } \\
\ldots\end{array}$ & $\begin{array}{c}3 \\
. .\end{array}$ & $\begin{array}{l}\cdots \\
\cdots\end{array}$ & $\begin{array}{l}\text { II } \\
. .\end{array}$ \\
\hline Neomysis vulgaris & $2 \mathrm{I}$ & $\ddot{1} 8$ & 7 & 6 & 29 & $\ddot{5}$ & $\because$ & $\begin{array}{l}\cdots \\
\cdots\end{array}$ & $\begin{array}{l}\cdots \\
\cdots\end{array}$ & 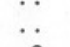 \\
\hline Schistomysis ornata & I5 & I4 & II & ro & 5 & $\because$ & I & $\cdots$ & .. & 3 \\
\hline Praunus flexuosus & 3 & Io & 3 & 4 & 13 & 8 & .. & .. & $\because$ & I \\
\hline Mysid fragments & 28 & 42 & 20 & 16 & 32 & 28 & $\cdots$ & .. & I & 6 \\
\hline $\begin{array}{l}\text { Caprella aequilibra } \\
\text { Pariambus typicus }\end{array}$ & $\cdots$ & $\ddot{I}$ & $\because$ & I & & $\cdots$ & $\cdots$ & $\because$ & $\because$ & . \\
\hline $\begin{array}{l}\text { Pariambus typicus } \\
\text { Corophium volutator }\end{array}$ & $\ddot{\cdots}$ & I & $\begin{array}{l}\cdots \\
\cdots\end{array}$ & $\ddot{2}$ & $\begin{array}{l}\cdots \\
\cdots\end{array}$ & $\ddot{I}$ & $\ddot{.}$ & $\begin{array}{l}\cdots \\
\cdots\end{array}$ & 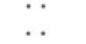 & $\ddot{8}$ \\
\hline $\begin{array}{l}\text { Gammarus locusta and Gam- } \\
\text { marus sp. }\end{array}$ & I2 & 8 & I & 9 & 16 & 18 & I & .. & . & I \\
\hline $\begin{array}{l}\text { Apherusa sp. } \\
\text { Amphipod fragments }\end{array}$ & $\because$ & $\ddot{I}$ & $\because$ & $\because$ & $\begin{array}{l}\mathrm{I} \\
8\end{array}$ & $\ddot{20}$ & $\ddot{I}$ & $\because$ & $\because$ & $\ddot{\mathrm{I}}$ \\
\hline $\begin{array}{l}\text { Amphipod fragments } \\
\text { Sphaeroma serratum and }\end{array}$ & $\begin{array}{l}4 \\
. .\end{array}$ & $\begin{array}{l}1 \\
\ldots\end{array}$ & $\begin{array}{l}\mathrm{I} \\
. .\end{array}$ & $\begin{array}{l}\cdots \\
.\end{array}$ & $\begin{array}{l}8 \\
4\end{array}$ & 20 & $\begin{array}{l}1 \\
. .\end{array}$ & $\begin{array}{l}\cdots \\
\cdots\end{array}$ & .. & \\
\hline $\begin{array}{l}\text { Sphaeroma serratum and } \\
\text { Sphaeroma sp. }\end{array}$ & & $\cdots$ & & & & & & & & .. \\
\hline Gnathiid larvae & I & . & . & . & I & .. & . & $\cdots$ & $\cdots$ & \\
\hline Cyprids of Balanus & I & . & $\cdots$ & . & 2 & .. & .. & .. & .. & $\because$ \\
\hline Temora longicornis & 5 & .. & $\therefore$ & $\because$ & $\ddot{7}$ & $\ddot{2}$ & ․ & $\because$ & $\cdots$ & .. \\
\hline Copepod fragments & 7 & $\because 2$ & $\ddot{3}$ & $\ddot{19}$ & 28 & $\begin{array}{l}2 \\
5\end{array}$ & $\ddot{I}$ & $\ddot{2}$ & $\begin{array}{l}\cdots \\
\therefore\end{array}$ & $\ddot{3}$ \\
\hline $\begin{array}{l}\text { Crustacean fragments } \\
\text { Arenicola sp. }\end{array}$ & $\begin{array}{l}35 \\
\ldots\end{array}$ & $\begin{array}{r}12 \\
I\end{array}$ & .. & .. & . & . & . & . & $\begin{array}{l}\cdots \\
\cdots\end{array}$ & \\
\hline Spirographis spallanzani & 6 & .. & .. & 2 & .. & .. & .. & .. & .. & $\because$ \\
\hline Nereis diversicolor & $\because$ & I & .. & $\because$ & . & I & . & . & . & $\mathrm{I}$ \\
\hline Polychaete remains & I & I & .. & I & $\cdots$ & 2 & . & . & . & $\because$ \\
\hline $\begin{array}{l}\text { Ova } \\
\text { Vegetable matter }\end{array}$ & I & $\because$ & . & . & . & . & .. & . & $\cdots$ & . \\
\hline Vegetable matter & . & I & $\cdots$ & $\cdots$ & $\cdots$ & $\cdots$ & $\cdots$ & $\cdots$ & $\cdots$ & • \\
\hline
\end{tabular}

Callionymus lyra L., the Dragonet

Dragonets were never numerous in the tuck-net hauls; I 28 fish were caught during the investigation. Of this number, ninety-six $(75 \%)$ were taken between April and September. At West Mud dragonets were more numerous than on the Saltash marks. Twenty-nine fish caught at West Mud on August 8 I936 belonged to two length-groups: one of 3-7 cm., with a mean length of $5.6 \mathrm{~cm}$. the second of IO-I3 cm., with a mean of II.9 cm. Fifteen fish taken on the same ground on June 25 1937, appeared to belong to a single length-group of $8-13 \mathrm{~cm}$., with a mean length of $10.7 \mathrm{~cm}$. Only one mature fish was taken, a male of I3 cm., at Saltash, in December 1935. 
The food of the dragonet is shown in Table X: various molluscs, Carcinus, Crangon and gammarid amphipods are the food organisms most frequently taken: but this fish is remarkable for the variety of its diet. The width of this variety is illustrated by the fact that twenty nine different food organisms were found in I 28 dragonets, and only twenty-five in II 57 flounders. Steven (I930) found the same catholic taste in food on the trawling grounds off Plymouth; but he found that Crangonidae were rarely caught, either because they were too agile, or because they live a little above the bottom where the fish usually hunts.

\section{Table X. Callionymus lyra: OCcurrence of Food Organisms}

The figures give the number of fish containing the specified category of food organism. Number of fish containing recognizable food $=$ II8.

Calyptraea chinensis
Hydrobia ulvae
Littorina sp.
Cardium edule
Paphia pullastra
Spisula solida
Scrobicularia plana
Macoma balthica
Pecten sp.
Mytilus edulis
Molluscan fragments
Carcinus maenas
Portunus sp.
Eupagurus bernhardus
Crangon vulgaris
Decapod larvae
Neomysis vulgaris
Mysid fragments
Caprellid fragments

$\begin{array}{rr}\text { I936 } & \text { I937 } \\ \text { I } & \cdots \\ \text { I } & \cdots \\ \text { I } & \cdots \\ 8 & 5 \\ 2 & \text { I } \\ \text { I } & \cdots \\ \text { I } & \cdots \\ \cdots & \text { I } \\ \text { I } & \cdots \\ 7 & \cdots \\ 2 & 2 \\ \text { IO } & \text { II } \\ \cdots & \text { I } \\ 3 & 2 \\ 3 & 25 \\ 5 & 4 \\ \text { I } & \text { I } \\ 2 & \text { I } \\ \text { I } & \text { I }\end{array}$

Corophium volutator
Gammarus marinus
Gammarus locusta
Gammarus sp.
Amphipod fragments
Sphaeroma sp.
Gnathiid larvae
Cirripede cyprids
Copepoda
Crustacean fragments
Spirographis spallanzani
Melinna palmata
Cirratulids indet.
Nephthys hombergi
Phyllodoce indet.
Polychaeta indet.
Oligochaeta indet.
Hydroid fragments
Algae

$\begin{array}{rr}\text { I936 } & \text { I937 } \\ 3 & 4 \\ \text { I } & \cdots \\ 5 & \cdots \\ 5 & 2 \\ \text { I6 } & 8 \\ \cdots & 3 \\ \text { I } & \cdots \\ 3 & \cdots \\ 8 & 2 \\ 22 & 2 \text { I } \\ \cdots & 7 \\ \text { I } & \text { I } \\ \text { I } & \cdots \\ \text { I } & \text { I } \\ \text { I } & \cdots \\ \cdots & \text { II } \\ \cdots & \text { I } \\ \cdots & 2 \\ \cdots & 3\end{array}$

Dragonets are "very common on the sandy trawling grounds" off Plymouth (Ford, I93I). The relatively small numbers which are taken in the estuaries suggest that the brackish and muddy conditions of the Tamar and Lynher are not well suited to them and that they therefore do not make use of the sheltered waters as a nursery ground.

\section{GOBIIDAE}

It seems that there has been a change in the goby population of the Tamar and Lynher since I928. Percival (I929), in his faunistic survey, made between June and November I928, mentioned only Gobius microps, which he found to be "present in great quantities". The common goby of the period from November 1935 to December 1937 was G. minutus: of 179 small gobies examined between May and December 1937, I74 were G. minutus and 5 G. microps. G. niger was caught occasionally, G. paganellus once and Aphya pellucida four times.

Only the feeding habits of the gobies were investigated. Samples of 
Gobius minutus large enough for the study of growth rates were not collected, and the other four species were not numerous enough to provide the necessary data. The food of the Gobiidae is shown in Table XI. Although so small a fish, G. minutus, feeding chiefly on shrimps and mysids, is a direct competitor with the flounder, bass and gadoids. On the other hand, the goby itself provides a meal for the larger fish of these competing species; and it is the principal food of the brill. Adult G. minutus fast in the breeding season.

\section{TABle XI. GobitdaE: Occurrence of Food Organisms}

The figures give the number of fish containing the specified category of food organism.

No. of fish containing
recognizable food
Clupea sprattus
Hydrobia ulvae
Cardium edule
Scrobicularia plana
Lamellibranch fragments
Carcinus maenas
Crangon vulgaris
Decapod larvae
Neomysis vulgaris
Schistomysis ornata
Praunus flexuosus
Mysid fragments
Corophium volutator
Gammarus sp.
Amphipod fragments
Copepod fragments
Ostracod indet.
Crustacean fragments
Spirographis spallanzani
Polydora ciliata
Cirratulids indet.
Nephthys hombergi
Nereis diversicolor
Polychaete remains
Hydroid remains
Spawn
Algal fragments

\section{Gobius \\ minutus}

86

\section{..}

.

$\cdots$

.

II

I I

I6

2

I
5
4

4
7

7
5
6

5
6
I

20

i

3

I

5

I

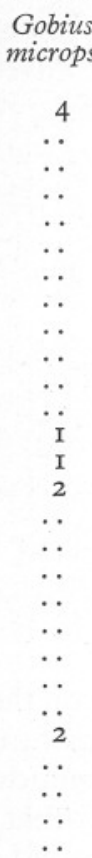

No. of fish containing recognizable food

Teleost fragments

Schistomysis ornata

$\begin{array}{cc}\text { Gobius } & \text { Gobius } \\ \text { niger } & \text { paganellus }\end{array}$

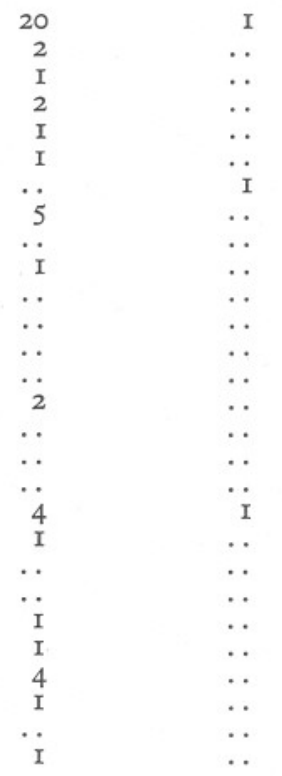

Aphya

pellucida

G. niger resembles Callionymus in the wide variety of its food, and eats more molluscs than most of the estuarine fish.

\section{Agonus cataphractus L., the Pogge}

Pogge were found on all the estuarine fishing grounds. On February 24 I936 big hauls of pogge were made on the Saltash marks; in a sample of fifty-five fish from this assembly, twenty-four were gravid females, $8-\mathrm{I} 3 \mathrm{~cm}$. 
long, and twenty-nine ripe males, $8-\mathrm{I} 2 \mathrm{~cm}$. long. It is probable that these fish had come together to breed. Russell (I937) found post-larvae off Plymouth in the same month.

Pogge feed almost entirely on crustaceans as shown below, especially amphipods and young Crangon vulgaris. The stomachs of twenty of the ripe fish caught in February 1936 were examined; nineteen contained food, so there is obviously no fast at the breeding time.

Food of Agonus cataphractus: Number of occurrences of each organism

Carcinus maenas
Crangon vulgaris
Schistomysis ornata
Mysid fragments
Corophium volutator
Gammarus locusta + Gammarus sp.
Melita palmata
Amphipod fragments
Crustacean fragments
Polychaete remains

$\begin{array}{rr}1936 & \text { I937 } \\ 3 & \mathrm{I} \\ 5 & \mathrm{I} \\ 3 & 2 \\ 4 & \mathrm{I} \\ \mathrm{I} & \mathrm{I} \\ 10 & 6 \\ 7 & . \\ 9 & \mathrm{I} \\ 7 & \mathrm{I} \\ \mathrm{I} & . .\end{array}$

Caranx trachurus L., the Horse Mackerel

Small horse mackerel are caught in the rivers in the late summer and early autumn. The length distribution of the fish was

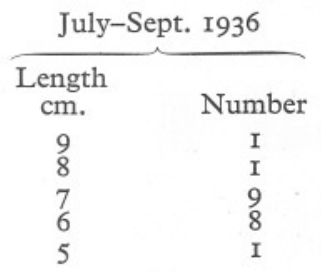

\begin{tabular}{|c|c|}
\hline \multicolumn{2}{|c|}{ July-Aug. I937 } \\
\hline $\begin{array}{c}\text { Length } \\
\mathrm{cm} .\end{array}$ & Number \\
\hline I8 & I \\
\hline 17 & I \\
\hline I6 & 3 \\
\hline I5 & 4 \\
\hline I4 & \\
\hline I3 & 3 \\
\hline
\end{tabular}

The fish taken in 1936 had been feeding on Neomysis vulgaris, while those caught the following year contained the remains of small clupeoids, and crustacean and polychaete fragments. It may be that the latter fish belong to the same year-class as those caught in the previous summer; but this is only a presumption.

In addition to these small fish, two horse mackerel of 34.5 and $30.6 \mathrm{~cm}$. were netted in September 1936; and two of 40.8 and $33.7 \mathrm{~cm}$. were caught in a drift-net in October of the same year. One of these four contained several small clupeoids; the other three were empty.

Morone labrax L., the Bass

The bass is a fish which has been very little studied. The adults usually live close inshore on rocky coasts and off harbour bars, where the heavy, broken water makes it difficult to catch them by any method but rod angling. Some 
fish are netted in the estuaries and sandy bays of south Devon and Cornwall, and caught by line-fishermen around the Drift Rock off Tenby (Parker, 1934); but in general the bass is a quarry of the amateur rather than of the professional fisherman. The scientific literature of this species is exceedingly scanty, and is devoted chiefly to descriptions of the morphology and occurrence of the larvae.

In the Tamar numbers of immature bass are taken in the tuck-nets during winter: the best hauls are made where the bottom is stony and when a stiff onshore breeze is blowing. Aflalo (1904) recorded that large bass, also, come
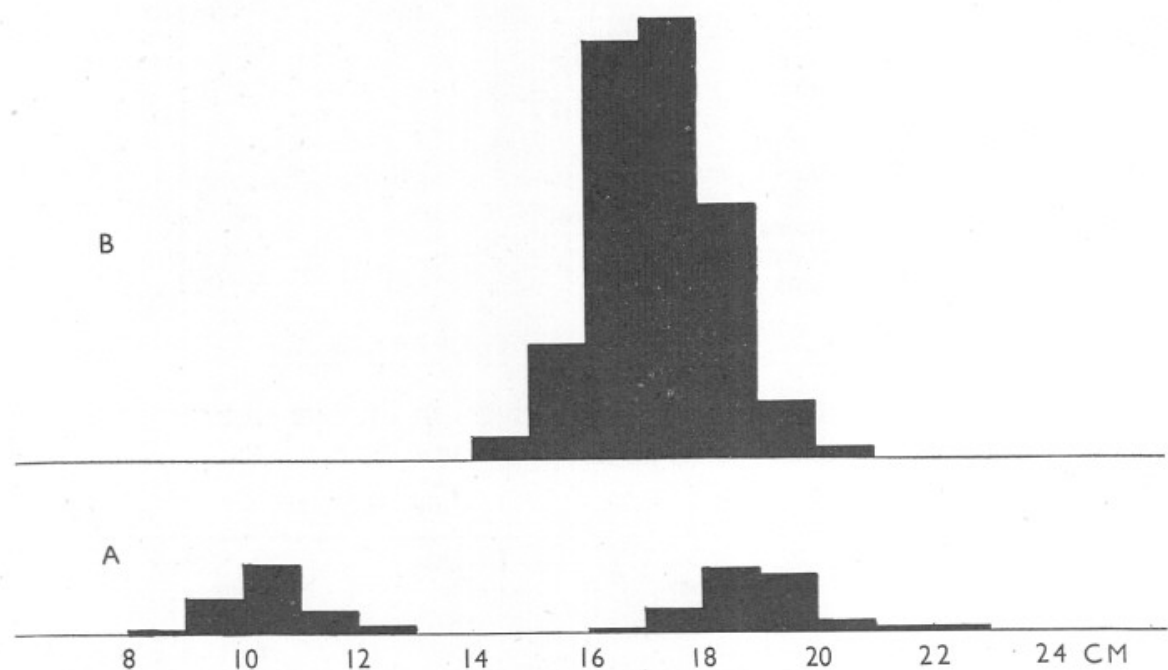

Fig. 16. Morone labrax; length frequency distributions. a, November 1935-April 1936. b, September 1936-April 1937.

close inshore after strong wind, when the water is cloudy and disturbed. The inshore movements of the estuarine fish seem to take place only in daylight, for bass are rare in catches made during the night. It may be, however, that the absence of bass from the night hauls is due to an uprising from the bottom, similar to the nocturnal upward movements of hake (Merluccius merluccius) (Hickling, 1925).

The fishermen regard the bass as one of the most valuable fishes in the estuaries, for only the salmon commands a higher price.

\section{Growth.}

In the winter of $1935^{-6}$ the length-frequency histograms for the bass showed two clearly defined groups (Fig. I6 $a$ ), the smaller fish averaging about $10.5 \mathrm{~cm}$. in length, the larger $19.0 \mathrm{~cm}$. Fish of these two groups were caught regularly until the spring of 1936 . There was practically no increase in length between November 1935, when the arithmetic mean lengths of the two 
groups were $10.5 \mathrm{~cm}$. (II fish) and $18.83 \mathrm{~cm}$. (27 fish), and February I936, when the means were $10.62 \mathrm{~cm}$. (I7 fish) and I9. I cm. (25 fish). During the summer of 1936, few bass were caught-a large fish of $29 \mathrm{~cm}$. in May, and four fish of $16.4,15.8,15.6$ and $15.5 \mathrm{~cm}$. in August.

In the autumn of 1936 and winter I936-7, many bass were seined-454 fish between September 1936 and April 1937. With the exception of a single fish of $7.5 \mathrm{~cm}$., caught in September, all these belonged to a single length-group (Fig. I6 $b$ ), corresponding with the larger of the two groups found in the previous year. The mean length of this group in September was $17.9 \mathrm{~cm}$. (23 fish): by November it had increased to $18.35 \mathrm{~cm}$. (34 fish): and by February to $18.47 \mathrm{~cm}$. (I27 fish). Through the summer of 1937 a few fish were taken in each month; the mean lengths of these very small samples showed a steady increase: to $20.5 \mathrm{~cm}$. in June ( $2 \mathrm{fish}$ ), and $22.83 \mathrm{~cm}$. (3 fish) in August. In the last months of 1937 only small numbers of bass were netted; the few fish obtained could be assigned to three different length groups of approximately IO, I8 and $26 \mathrm{~cm}$.

The simplest interpretation of the length-grouping of young bass in the river is that there were two year-classes in I935-6, the larger class being one year older than the smaller. The failure of the larger length-group in I937, one year after a failure of the smaller group supports this view. Newlyhatched bass are rare off Plymouth; among fourteen post-larvae measured between I925 and I933 (Russell, I935), those taken in April were from 4 to $7.5 \mathrm{~mm}$. in length. The attainment of a length of $\mathrm{IO} \mathrm{cm}$. within the first growth period is by no means impossible: herring, which never reach the size of adult bass, may grow to such a length within a year (Ford, I928). It is therefore suggested that the "IO cm. long" fish are the O-group, and the "I $8 \mathrm{~cm}$." fish the I-group. In the winter of $1935-6$, both groups were well represented. In I936, all the I-group fish appear to have gone down to the sea at the end of March, for many O-group bass were netted in April, but none of the larger size. In the winter of $1936-7$, the I-group was strongly represented, but there was a complete failure in the recruitment of the stock. This lack of fish of the I936 class was reflected in the winter of $1937-8$ by a lack of I-group fish. The recruitment in 1937 was again a failure. Most of the fish of the I935 class left the estuaries in the spring of 1937 as I-group fish, but a few remained through the summer, and as II-group fish were some $26 \mathrm{~cm}$. long in the middle of winter $1937-8$.

Patterson (I9I3) observed a rather similar length distribution of young bass in Breydon Water: "There were unprecedented numbers of small bass, locally known as 'sea perch', taken on Breydon Water in August and September (I9I3). In August they measured $4 \frac{1}{2}$ in. (II.4 cm.); some taken in October I measured at $7 \frac{1}{2}$ in. (I9.05 cm.), an evident quick growth of 3 in. in 3 months." It is more probable that these fish actually belonged to different year-groups, the O-group and the I-group, rather than that an increment of $7.5 \mathrm{~cm}$. should have taken place in so short a time. 
Large bass are very rare in the estuaries; I saw only one big fish in more than two years' work. This was a specimen about $75 \mathrm{~cm}$. long, taken in a salmonnet at Sheviock in July 1937. Holt \& Byrne (I898) suggested that the estuaries might be a spawning ground of bass, but the complete lack of mature fish is against such a view. The tidal reaches of the rivers are a nursery ground, deserted for the sea before the gonads begin to mature.

Growth in the bass seems to take place during the summer months, with a period of no increase in winter. Ford (1937) found that the supraoccipital

\section{Table XiI. Morone labraX: Occurrence of Food Organisms}

The figures give the number of fish containing the specified category of food organism for each month.

Number of fish containing recognizable food

Teleost fish

Oikopleura sp.

Carcinus maenas

Leander sp.

Crangon vulgaris

Praunus flexuosus

Neomysis vulgaris

Schistomysis ornata

Mysids indet.

Sphaeroma sp.

Gammarus sp.

Corophium volutator

Amphipods indet.

Crustacea indet.

Nereis diversicolor

Phyllodoce sp.

Polychaeta indet.

Number of empty fish

$$
\text { I936 }
$$

\begin{tabular}{|c|c|c|c|c|c|c|c|c|c|c|c|}
\hline Jan. & Feb. & Mar. & Apr. & May & June & July & Aug. & Sept. & Oct. & Nov. & Dec. \\
\hline . & 7 & . & . & . & I & . & 4 & I9 & 34 & I7 & . \\
\hline$\ldots$ & $\ldots$ & $\ldots$ & $\ldots$ & $\ldots$ & $\ldots$ & $\ldots$ & $\ldots$ & I & 5 & 2 & $\ldots$ \\
\hline$\cdots$ & $\cdots$ & $\cdots$ & $\cdots$ & $\cdots$ & . & $\ldots$ & $\ldots$ & I & $\ldots$ & $\ldots$ & $\ldots$ \\
\hline . & $\ldots$ & $\ldots$ & $\ldots$ & $\ldots$ & $\ldots$ & $\ldots$ & $\ldots$ & 2 & $\ldots$ & I & $\ldots$ \\
\hline . & $\cdots$ & $\ldots$ & $\cdots$ & . & . & . & . & . & . & . & $\cdots$ \\
\hline$\ldots$ & I & $\ldots$ & $\ldots$ & $\ldots$ & I & $\ldots$ & 3 & I6 & I9 & I2 & $\ldots$ \\
\hline$\ldots$ & $\ldots$ & $\ldots$ & $\ldots$ & $\cdots$ & . & $\cdots$ & I & 3 & $\ldots$ & $\ldots$ & $\ldots$ \\
\hline . & I & . & . & $\ldots$ & . & . & . & . & 4 & I & . \\
\hline$\ldots$ & I & $\cdots$ & $\cdots$ & $\ldots$ & $\ldots$ & $\ldots$ & $\ldots$ & $\ldots$ & $\ldots$ & $\ldots$ & $\cdots$ \\
\hline$\cdots$ & 2 & $\cdots$ & $\ldots$ & $\cdots$ & .. & $\cdots$ & I & $\cdots$ & IO & I & $\ldots$ \\
\hline$\cdots$ & $\cdots$ & $\cdots$ & $\cdots$ & $\cdots$ & $\cdots$ & $\cdots$ & $\cdots$ & $\cdots$ & $\cdots$ & $\cdots$ & $\cdots$ \\
\hline$\cdots$ & 2 & $\cdots$ & $\cdots$ & $\ldots$ & . & $\ldots$ & $\ldots$ & $\ldots$ & 2 & $\ldots$ & $\ldots$ \\
\hline$\ldots$ & I & . & $\ldots$ & $\ldots$ & . & . & . & . & . & . & $\cdots$ \\
\hline$\ldots$ & I & $\ldots$ & $\ldots$ & $\ldots$ & . & $\ldots$ & $\ldots$ & $\ldots$ & I & I & $\ldots$ \\
\hline$\ldots$ & I & $\cdots$ & $\ldots$ & $\ldots$ & $\ldots$ & $\ldots$ & I & I & 4 & 5 & $\cdots$ \\
\hline$\cdots$ & . & $\cdots$ & $\ldots$ & $\cdots$ & $\cdots$ & $\cdots$ & $\cdots$ & $\ldots$ & . & . & $\cdots$ \\
\hline$\cdots$ & $\cdots$ & $\cdots$ & $\cdots$ & $\cdots$ & $\cdots$ & $\cdots$ & $\cdots$ & $\ldots$ & $\ldots$ & . & $\cdots$ \\
\hline$\cdots$ & $\cdots$ & $\cdots$ & $\cdots$ & $\ldots$ & $\cdots$ & $\ldots$ & $\cdots$ & $\cdots$ & $\cdots$ & I & $\cdots$ \\
\hline$\ldots$ & 7 & $\ldots$ & $\ldots$ & $\ldots$ & 0 & $\ldots$ & 0 & 2 & 8 & I & $\cdots$ \\
\hline
\end{tabular}

Number of fish containing recognizable food

Teleost fish

Oikopleura sp.

Carcinus maenas

Leander sp.

Crangon vulgaris

Praunus flexuosus

Neomysis vulgaris

Schistomysis ornata

Mysids indet.

Sphaeroma sp.

Gammarus sp.

Corophium volutator

Amphipods indet.

Crustacea indet.

Nereis diversicolor

Phyllodoce sp.

Polychaeta indet.

Number of empty fish

$\overbrace{\text { Jan. Feb. Mar. Apr. May June }}^{\text {I9 }}$ J

\begin{tabular}{|c|c|c|c|c|c|c|c|c|c|c|c|}
\hline II & I3 & 20 & 7 & .. & I & I & 3 & I & . & 4 & 2 \\
\hline . & $\cdots$ & .. & . & . & . & . & I & I & . & $\therefore$ & . \\
\hline . & $\cdots$ & . & . & . & . & . & . & .. & . & . & . \\
\hline . & $\cdots$ & I & I & . & . & . & I & . & . & 3 & . \\
\hline 0 & $\ddot{8}$ & 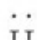 & . & . & 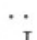 & . & I & .. & . & $\because$ & $\because$ \\
\hline 9 & & 11 & 4 & . & 1 & . & $\mathrm{I}$ & . & $\cdots$ & 3 & I \\
\hline . & $\cdots$ & 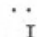 & " & " & - & ". & " & . & $\cdots$ & $\cdots$ & $\cdots$ \\
\hline$\because$ & $\therefore$ & .. & $\because$ & 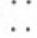 & 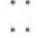 & 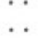 & 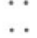 & $\because$ & $\because$ & $\because$ & $\because$ \\
\hline & . & .. & . & .. & .. & . & . & .. & . & $\ldots$ & I \\
\hline I & $\cdots$ & 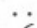 & . & . & .. & . & . & . & .. & . & $\ldots$ \\
\hline . & 2 & 6 & .. & . & . & I & . & .. & $\ldots$ & . & $\ldots$ \\
\hline & $\cdots$ & . & . & . & . & . & . & . & . & .. & . \\
\hline 2 & I & $\because$ & $\because$ & . & . & $\because$ & . & .. & $\cdots$ & .. & $\cdots$ \\
\hline 2 & I & 3 & I & . & . & I & . & . & . & . & $\cdots$ \\
\hline 4 & 2 & 3 & I & . & . & . & $\ldots$ & . & . & I & . \\
\hline & 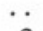 & I & . & .. & .. & . & . & . & .. & . & . \\
\hline I & 2 & 2 & . & .. & $\cdots$ & . & $\cdots$ & . & $\cdots$ & 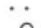 & 0 \\
\hline 3 & . & 12 & 9 & . & 0 & 0 & o & 0 & . & ० & 0 \\
\hline
\end{tabular}


bone of this fish "exhibits growth zones of remarkable clarity". This phenomenon is consistent with a periodically interrupted process of growth.

\section{Feeding Habits.}

The bass is a hunter of active prey. Crustaceans, especially Crangon vulgaris and mysids, form the bulk of its food (Table XII). Nereis diversicolor and other polychaetes, and small teleost fish make up the rest of its diet. There is no marked change in feeding habits with increasing size. Some of the larger organisms are available only to the older fish, but throughout the period of estuarine life crustaceans form the bulk of the food consumed. In its feeding habits, the bass is a direct competitor with the flounder.

\section{Scomber scombrus L., the Mackerel}

In the autumn of some years, big hauls of mackerel are made in the estuaries. As many as 300 fish have been caught in one shot of a tuck-net on West Mud. The fishermen say that a good sprat year is also a good year for mackerel, as the mackerel follow, and feed on, the shoals of sprats.

Neither 1936 nor 1937 were "mackerel years". There were no fish at all in 1936, and only a few in 1937, when some fish were netted in Barn Pool, near the mouth of the Hamoaze in early August. Only eleven mackerel were caught during the investigation. These fish had all fed on sprats; one contained a single Crangon vulgaris in addition.

\section{OTHER SPECIES}

A variety of other species of fish are liable to occur in the Tamar Estuary, but only sporadically in small numbers. Those actually taken are recorded in Table XIII.

\section{Fishes AND the Bionomics of the Estuarine ANimal CoMmunity}

The life histories of the fishes caught in the estuaries have been considered species by species: it remains to consider the fish population as a whole, and as a part of the general community of estuarine animals. The essential organization of animal life in an estuary is that of a resident population providing food for a number of migratory predators. The period of estuarine life of these predators varies with the species, from about nine months in the case of a gadoid to three or four years in the flounder. In considering these immigrations of marine organisms three types of invasion may be distinguished-annual, irregular and sporadic.

The annual invasions are the means of recruiting the populations of those species of fish which are regularly resident within the rivers. In general the invasion by each species will take place at the same time each year. Most 


\section{Table XIII. Records of Species of Which Six or Less Individuals WERE CAPTURED}

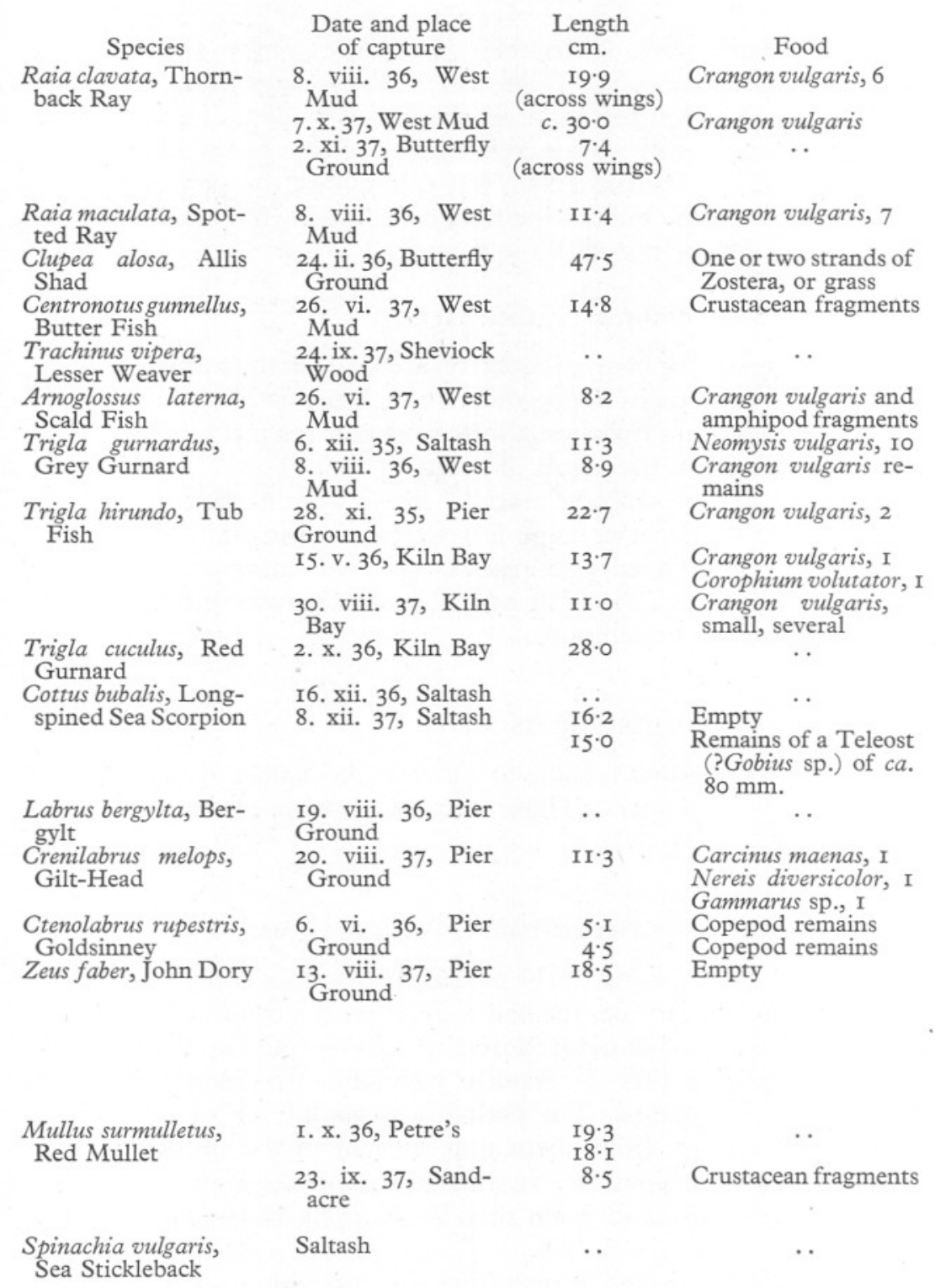

Three fish

In the "old days" John Dories were caught under the ferry lights at Saltash: now they are considered to be very rare

Ford (I93I) records Red Mullet in the Lynher

Several specimens were captured on rough ground near Saltash 
species recruit their populations in the early summer, when the O-group come in from the sea; but the herring has two separate immigrations, the O-group in summer and the I- and II-group fish in the autumn. All those fishes which show an increase of population by regular invasion have a corresponding process of decrease by the return to the sea of the same fish at a later stage of their life history.

Other predators beside fishes come regularly to the estuaries. Every winter a number of cormorants (Phalacrocorax carbo carbo) feed daily in the Tamar and Lynher. Steven (I933) found that flatfishes formed nearly $40 \%$ of the numerical total of fishes taken by cormorants on the coasts of Cornwall, and that very nearly half of the fishes eaten by these birds were of marketable species. Observations made during the winter of $1936-7$ showed that approximately I50 cormorants visited the rivers daily, and that each bird fed two or three times during the day. Since a cormorant can easily eat a $200 \mathrm{~g}$. flatfish at a meal, and often takes considerably more, the steady toll which they exact from the fish population must be an ecological factor of some importance. Large numbers of wading birds visit the rivers each winter, and compete with the fish for such foods as Cardium, Carcinus and Nereis.

One other animal swarms in the estuaries each year, the scyphozoan Aurelia aurita. Allen (I93I) records it as "most abundant in the estuaries in spring and summer". Percival (I929) found that "Aurelia aurita breeds extensively in the asexual stage on the mussel bed of Neille Point. The medusae regularly invade the river during the summer months...." In 1936 Aurelia was first seen on April 22, and by May 23 had become so numerous that a tuck-net could not be worked on the Kiln Bay ground, owing to the huge masses of jelly-fish which blocked the meshes and filled the cod-end. In early June the salmon fishers also were hindered by the great numbers of Aurelia. In the following year, Aurelia was not seen until May 5. It never became numerous in the lower part of the estuaries, and was not common enough to be a nuisance in the upper reaches until the end of June. Large numbers of juvenile Aurelia, preying directly on young fish, and the older medusae living on zooplankton (Lebour, I923), introduce additional end-points into the food chains of estuarine animals.

The irregular invasions are of those species which appear in some years only-the mackerel is the best example. It is probable that the irregular migrants have a comparatively small effect on the resident fauna of the estuaries, and only appear when some organism suitable for their food is unusually abundant: for example, I am told by the fishermen that mackerel only appear when the numbers of young sprats and herring are exceptionally large.

Several sporadic invasions were seen during the period of the investigation. The most remarkable was the sudden appearance of large numbers of Pleurobranchus membranaceus in October 1936: none of the local fishermen had ever seen such a creature before, and some of them were of the opinion that the animal was "some kind of spawn". The immigration of this species, 
too large to be eaten by fish, probably has very little effect on the animal community in general, for it neither increases the supply of food for the predators nor the competition for food among them. On the other hand, an invasion of predatory animals, such as the cephalopods Sepia officinalis and Alloteuthis subulata, which appeared in the summer of 1937, must increase the competition for animal food. Alternatively, some invasions of smaller organisms may increase the supply of food-for example, in September 1937 Caprella aequilibra was found in the stomachs of several of the dabs and pout caught during one day's fishing.

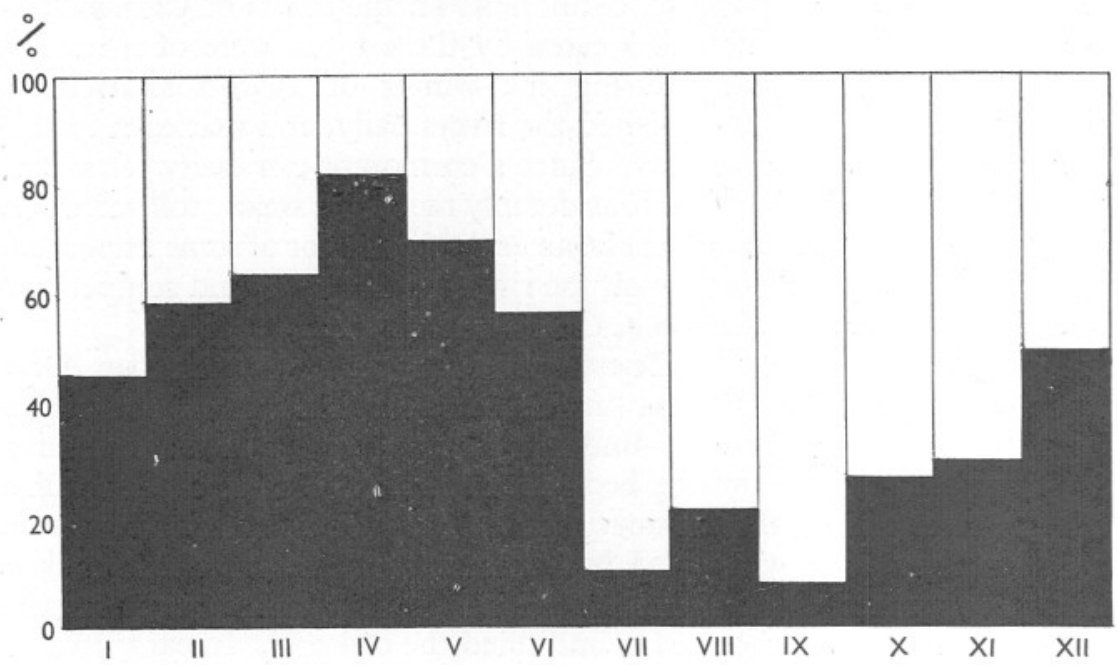

Fig. 17. Frequency of occurrence of Schistomysis ornata and Neomysis vulgaris in the food of estuarine fishes. (Expressed as percentages of the total monthly occurrences of S. ornata, black, and $N$. vulgaris, white.)

The number of species which are resident in the estuaries throughout their lives is small: and the number of different animals decreases with increasing distance from the sea. The composition of the resident invertebrate fauna varies from month to month. There is more than the obvious variation in numbers and size owing to the annual breeding season. Different species reach their maximum numbers at different times, and so bulk large or small in the diet of fishes at different seasons. This is well shown by the Mysidacea. Of the four mysids recorded by Percival, two, Neomysis vulgaris and Schistomysis ornata, are important fish foods. Fig. I7 shows the relative proportions in which these two species occur in fish stomachs from month to month. It will be seen that from February to June $S$. ornata occurs more frequently than $N$. vulgaris: that in the period July to November $N$. vulgaris is more numerous: and that in the depth of winter the two occur with equal frequency. The calculation was made from the combined figures for 1936 and 1937, from all species of fish. It may be suggested that this change in frequency of occurrence 
is due to a change in selection; but this explanation would be correct only in the improbable event of a simultaneous change in choice on the part of some twenty different species of fish. Percival says of Schistomysis ornata that it "had the shortest range and the least significance from the point of view of numbers". Since Percival's collections were made between June and November it seems probable that the period in which $S$. ornata was most numerous was missed, with the result that the importance of the organism in the estuarine fauna was not realized. Tattersall (I938) found S. ornata to be the dominant species in the winter maximum of mysids off Plymouth.

A result of the small number of wholly estuarine animals is that many kinds of fish are compelled to seek the bulk of their food in the ranks of a limited number of species. Crangon vulgaris, mysids, especially Neomysis and Schistomysis, and the polychaete Nereis diversicolor, are eaten by practically every species of fish in the rivers. It seems probable that there must be some competition for these commonest species.

On the basis of feeding habit, the fishes of the estuaries may be divided into four categories:

(I) Fish without competitors: the grey mullets are the sole example.

(2) Fish which feed to some extent upon the commonest organisms, but take the bulk of their food from species for which there is less competition: for example, the dab and the brill.

(3) Fish which feed to some extent on the commonest organisms, but have a wide choice of foods, and are thereby relieved from the effects of severe competition: for example, the plaice, the dragonet and Gobius niger.

(4) Fish which have many direct competitors for the bulk of their food: for example, the flounder, the bass and the gadoids.

On the first category it is necessary to make little comment. The grey mullets of the estuaries are exclusively vegetarian, and their food supplies are available for their use without competition from any other fish. The fundamental balance between the number of animals and the amount of food must be maintained: but the competition being entirely intrageneric, the grey mullet population is able to make full use of the available pasture.

The members of the second category are in a situation scarcely less favourable. The case of the dab is typical. When the young fish first enter the estuaries, they feed upon small crustaceans in direct competition with the juvenile members of other species. Within a few weeks, however, their diet begins to change, for the fish becomes large enough to feed upon the sabellid, Spirographis spallanzani, which is the staple diet of the species during estuarine life. Although some crustacean diet will always be taken, and though some other fish eat small numbers of Spirographis, the dab is largely freed from interspecific competition as soon as it becomes big enough to nip off and swallow a few sabellid tentacles. The total production of dab in any year must be to some extent controlled by the total production of worm. Were the supplies of Spirographis to fail, it is probable that the dabs could maintain themselves, 
and grow, on some other diet-for example, Crangon vulgaris. This, however, could only be done in the face of considerable competition from other species.

The fish of the third category obtain a measure of freedom from interspecific competition by a different method. The plaice, a typical fish of this category, feeds with apparently equal zest upon a large assortment of foods. For example, in the dab, only three groups of polychaete occurred ten or more times-Spirographis, Polydora sp. and cirratulids, and of the recognizable polychaetes, $93 \%$ were Spirographis: in the plaice, seven groups of polychaetes occurred ten or more times-Spirographis, Ampharete grubei, Melinna palmata, Nephthys hombergi, Nereis diversicolor, Polydora sp. and cirratulidsand Nephthys, the most numerous, made up only $21 \%$ of the recognizable forms. It was observed that fishes having a wide choice of foods were the only species which fed with any frequency upon molluscs.

It should, perhaps, be emphasized that a species is not limited to one of these categories. The dab shows a considerable width of choice in its food: but is most remarkable for its concentration upon one of many possible articles of diet.

There remain a number of fish, including some of those most numerous in the rivers, which are subject throughout their estuarine lives to steady interspecific competition for the bulk of their food. These are the fish which feed largely on Crangon, mysids and amphipods-the flounder has competitors for every item in its diet. The success of a year-group of any one of the fish in this category depends not only on the numerical strength of the recruitment of its own species, but on the size of the corresponding year-groups of its competitors.

It is, of course, possible that there is enough food for all the fish in the estuaries to grow at maximum speed, and that competition for food is more apparent than real. Extensive transplantation experiments with marked fish might reveal retarded growth within the estuaries, but could not show whether the hurtful competition was inter- or intraspecific. Observations made over a long period, in which numerical fluctuations in the year classes of different species and the growth rates of each year class were noted, would provide material from which inferences on the effects of competition might be made. From this two-year study of the estuaries one suggestion may be put forward. The growth rate of the flounder was found to be lower than that of populations in Europe: the growth rate of the dab seemed to be higher. It may be that there is a connexion, on the one hand, between the retarded growth of the flounders, and the steady competition for food which they must face, and, on the other, between the rapid growth of the dabs and their comparative freedom from interspecific competition.

The small number of molluscs eaten by the estuarine fishes is remarkable. In many localities plaice and dabs feed largely on molluscs: in the North Sea Todd (1915) found that plaice ate more molluscs than anything else, and that dabs competed with them for that diet. On the trawling grounds east of Plymouth, Cultellus pellucidus is an important food of the dab. Ford (1925) has pointed out that "before the potential value of a bed of lamellibranchs as 
food for fishes can become known, the precise food value of the successive stages in the life history of each lamellibranch must be determined". If the limited number of species of lamellibranch inhabiting the estuaries have rapid growth rates, they may very quickly become too large to be preyed upon by the immature flatfish. Of the five marine species listed by Percival (I929) four -Mytilus edulis, Scrobicularia plana, Paphia pullastra and Cardium edule-do, in fact, grow to a large size. It is known that the food taken by a fish is dictated by its hunting habits (Steven, I930). Within the range of possibility of any one species there is usually a considerable variety of diets, and the food chosen may be dictated by two factors beside that of simple availability. The possible factors are "preference" and a habit-formation resulting from the interaction of this preference with availability. The fact that one article of diet may be preferred to another by a member of the higher vertebrates is a matter of common experience: and it is probable that a fish also will select one food rather than another, for no more reason than that it "likes" the chosen food. Scott (I922) found that in young plaice "individuals in a catch are found to have been feeding on one particular species, although it is quite obvious from the examination of the stomachs of their companions that species belonging to the same group and to other groups, were present". Wailes (I935) found that in the Pacific herring (Clupea pallasii) "there is evidence for belief in individual specialization on certain types of food". Allen (1938) found that brown trout (Salmo trutta) showed an individual selection of food organisms.

It is, moreover, possible to accustom fishes to a wholly unnatural diet-as witness the ordinarily vegetarian grey mullet in the Plymouth tank room, which have formed the habit of eating pieces of chopped squid, in the absence of vegetable food. If there are comparatively few molluscs of a sufficiently small size in the estuaries, the fishes may form a habit of eating other organisms, with the result that shellfish are taken in even smaller numbers than their density on the ground warrants.

The feeding habits of the members of an animal community may be closely observed. The food taken may be compared with the available supply, and special preferences or rejections noted. Changes in diet and similarities in diet may be listed: but, at the end, there must remain wide gaps in the exact knowledge of the relationships between the different species. It is rarely possible to say that the effect of one species upon another is wholly beneficial, or wholly destructive. Competition for a similar diet can only affect the competing organisms when there is not enough food for all of them to feed to repletion at all seasons of the year. When the food supplies for a species are inadequate, the reduction in numbers caused by a predator can only benefit the survivors. Cormorants removing 500-1000 fish a day from the estuaries may serve to increase the growth rate of those which are left: the loss from the point of view of numbers is severe: the loss in total weight of fish may not be great. Small Aurelia aurita reduce the number of the juvenile fish which have newly entered the estuaries: but the larger medusae compete with the survivors for zooplanktonic organisms. The effect of the scyphozoan upon the fish may 
be beneficial at one stage in its life history and is almost certainly detrimental at another. The large flounder which consumes a number of Gobius minutus removes so many of the competitors with the young fish of its own species.

If, on the other hand, the habitat be capable of supporting an excess of food for all the predators, the relationships between the members of the community are simplified. The effect of each predator upon its prey is wholly unfavourable, not only from the individual but from the specific point of view. Only investigations on an enormous scale-quantitative faunal surveys of vast extent, biochemical assays of the food value of every species, experimental studies of populations in captivity and of the dietetic demands of each member of the fauna-could reveal the exact balance that exists between the different members of an animal community. But even a limited investigation of that community can show the possibilities of competition between organism and organism, and the actual reactions of certain species to the sum of the environmental factors working upon them.

\section{SUMMARY}

The Saltash tuck-net is used in the estuaries of the Tamar and Lynher for seine netting on soft mud. The fishery is carried on during autumn and winter, from open boats with crews of two men.

Hauls were made with a tuck-net in every month between November 1935 and December 1937.

The fish population of the estuaries is essentially marine: its composition changes from month to month with the arrival from, or departure to, the sea of different species of fish. With the exceptions of salmon (Salmo salar), sea trout (Salmo trutta) and some of the Gobiidae, all the fishes of the estuaries go down to the sea to spawn.

The flounder (Pleuronectes flesus) is the typical fish of the estuaries. Flounders live in the estuaries until the onset of sexual maturity, when they go down to the sea to spawn: a few female flounders return to brackish waters after spawning. The growth rate of the flounder varies greatly from fish to fish. At two years old the mean length is about II cm., and at four years it is I8 $\mathrm{cm}$. The food of the flounder consists of Crustacea and Polychaeta.

The other species of fish living in the estuary are listed, with remarks upon their periods of estuarine life, growth rates and food.

The relationships between the members of the estuarine fish community are discussed.

\section{REFERENCES}

Aflalo, F. G., I904. British Salt-Water Fishes. London.

Allen, E. J., I93I. Plymouth Marine Fauna. Second Edition. Plymouth.

Allen, K. R., 1938. Some Observations on the Biology of the Trout (S. trutta) in Windermere. Fourn. Anim. Ecol., Vol. vII, pp. 333-49.

Ascroft, R. L., I900. Notes on the White Fluke, or Flounder. Trans. Liverpool Biol. Soc., Vol. xIv, p. I74.

Blegvad, H., 1932. On the Flounder [Pleuronectes flesus L.] and the Danish Flounder Fishing in the Baltic. Cons. Int. Expl. Mer., Rapp. Proc. Verb., Vol. Lxxvin, pp. I-28. 
Cunningham, J. T., I896. Marketable Marine Fishes. London.

Davis, F. M., I937. An Account of the Fishing Gear of England and Wales. Min. Agric. and Fish., Fish. Invest., Ser. II, Vol. xv, No. 2. London.

Dawes, B., 1930. Growth and Maintenance in the Plaice (Pleuronectes platessa L.) Part I. Fourn. Mar. Biol. Assoc., Vol. xvII, pp. I03-74.

Duncker, G., 1899. Variation und Asymmetrie bei Pleuronectes flesus L. Wiss. Meeresuntersuch. Abt. Helgoland, Bd. III, pp. 333-406.

Ehrenbaum, E., I9ir. Über die Flunder [Pleuronectes flesus L.]. Aus deutscher Fisherei. Neudamm.

— 1929. Die Flunder Pleuronectes flesus L. Handbuch der Binnenfischerei Mitteleuropas, Bd. III, pp. III-29.

FIsCHER, E., I932. "Ist die Einführung einer Schonzeit für die Flunder der Ostsee erforderlich?" Cons. Int. Expl. Mer. Rapp. Proc. Verb., Vol. LxxviII (4), pp. I-I2.

ForD, E., I925. On the Growth of some Lamellibranchs in Relation to the FoodSupply of Fishes. Fourn. Mar. Biol. Assoc., Vol. xIII, pp. 531-59.

- I928 a. Herring Investigations at Plymouth. IV. The growth of young herrings in the neighbourhood of Plymouth. Fourn. Mar. Biol. Assoc., Vol. xv, pp. 305-I9.

- $1928 \mathrm{~b}$. Herring Investigations at Plymouth. III. The Plymouth Winter Fishing during the Seasons 1924-25, 1925-26 and 1926-27. Fourn. Mar. Biol. Assoc., Vol. xv, pp. 279-304.

- I931. Plymouth Marine Fauna. Second Edition. Plymouth.

- 1933. An Account of the Herring Investigations Conducted at Plymouth during the Years from 1924 to I933. Fourn. Mar. Biol. Assoc., Vol. xIx, pp. 305-84.

— 1937. Vertebral Variation in Teleostean Fishes. Fourn. Mar. Biol. Assoc., Vol. xxII, pp. I-60.

Graham, M., I93I. Some Problems in Herring Behaviour. Fourn. Cons. Int. Explor. Mer., Vol. vI, pp. 252-65.

Hickling, C. F., 1925. Notes on Euphausiids. Fourn. Mar. Biol. Assoc., Vol. xIII, pp. $735-45$.

Hartley, P. H. T. \& Spooner, G. M., 1938. The Ecology of the Tamar Estuary. I. Introduction. Fourn. Mar. Biol. Assoc., Vol. xxiI, pp. 50I-8.

Holt, E. W. L. \& Byrne, L. W., I898. Notes on the Reproduction of Teleostean Fishes in the South-Western District. Fourn. Mar. Biol. Assoc., Vol. v, pp. 333-9.

KANDLER, R., I932. Veränderungen im Flundernbestand der Ostsee durch die Fischerei. Cons. Int. Expl. Mer., Rapp. Proc. Verb., Vol. LxxviII, III, pp. I-45.

LARSEN, K., I936. The Distribution of the Invertebrates of the Dybsø Fjord, their Biology and their Importance as Fish Food. Rep. Dan. Biol. Stat. xLI, pp. 3-36.

Lebour, M. V., I923. The Food of Plankton Organisms. II. Fourn. Mar. Biol. Assoc., Vol. xIII, pp. 70-92.

LÜbbert, H. \& Ehrenbaum, E., 1936. Pleuronectes flesus. Handbuch der Seefischerei Nordeuropas. Bd. II, pp. 2I6-I9.

MenZies, W. J. M., I938. Salmon Fishing in 1938. The Field, February 5 1938.

Molander, A. R., I932. Der Flunderbestand in der südlichen Ostsee, und der Einfluss den die Fischerei auf ihn ausübt. Cons. Int. Expl. Mer., Rapp. Proc. Verb., Vol. LXxviII, v, pp. I-I5.

MurIE, J., I903. Report on the Sea Fisheries and Fishing Industries of the Thames Estuary. Kent and Essex Sea Fisheries Committee. London.

Nall, G. H., I930. The Life of the Sea Trout. London.

O'Donoghue, C. H. \& Boyd, E. M., I930. A Preliminary Investigation of the Food of the Sea Trout (Salmo trutta) Fisheries. Scotland, Salmon Fish., No. III.

PARKer, E., I934. English Wild Life. London.

Patterson, A. H., I904a. Notes of an East Coast Naturalist. London. 1904b. Some Fish Notes from Great Yarmouth for 1904. Zoologist, Ser. 4, Vol. vIII, pp. 44I-4.

- 1906. Some Fish Notes from Great Yarmouth for 1906. Zoologist, Ser. 4, Vol. x, pp. $453-8$. 
PAterson, A. H., I907. Wild Life in a Norfolk Estuary. London.

- r913. Some Fish Notes from Great Yarmouth for I913. Zoologist, Ser. 4, Vol. XVIII.

Percival, E., I929. A Report on the Fauna of the Estuaries of the River Tamar and River Lynher. Fourn. Mar. Biol. Assoc., Vol. xvi, pp. 8I-Io8.

Poulsen, E. M., I933. Biology of the Dab in Danish Waters. Rep. Dan. Biol. Stat. XXXVIII, pp. 9-30.

Russell, F. S., I926. The Vertical Distribution of Marine Macroplankton. IV. The Apparent Importance of Light Intensity as a Controlling Factor in the Behaviour of Certain Species in the Plymouth Area. Fourn. Mar. Biol. Assoc., Vol. xIv, p. 4I5.

- 1930. The Seasonal Abundance and Distribution of the Pelagic Young of Teleostean Fishes Caught in the Ring-trawl in Offshore Waters in the Plymouth Area. Fourn. Mar. Biol. Assoc., Vol. xvi, pp. 707-22.

- I935. On the Occurrence of the Post Larval Stages on the Bass, Morone labrax (L.), in the Plymouth Area. Fourn. Mar. Biol. Assoc., Vol. xx, pp. 7I-2.

— I937. The Seasonal Abundance etc. Part IV. The Year 1936, with Notes on the Conditions as Shown by the Occurrence of Plankton Indicators. Fourn. Mar. Biol. Assoc., Vol. xxI, pp. 679-86.

- I938. On the Seasonal Abundance of Young Fish. V. The year 1937. Fourn. Mar. Biol. Assoc., Vol. xxir, pp. 493-500.

SchNACKENBECK, W., I926. Biologische Untersuchungen über den Elbbutt. Der Fischerbote, Vol. XviII, pp. 223-4I.

- 1929. Die Fische von Nord- und Ostsee. Leipzig.

— 1936. Die biologische Grundlagen für die Fischerei in der Niederelbe. Die Fischmarkt.

ScotT, A., I895. Examination of Food in Fishes' Stomachs. Lancashire Sea Fisheries Report for I895. pp. 6-I2.

- 1906. Notes on the Food of Young Fishes. Trans. Liverpool. Biol. Soc., Vol. xxI, pp. I99-203.

- I922. On the Food of Young Plaice (Pleuronectes platessa). Fourn. Mar. Biol. Assoc., Vol. xII, pp. 678-87.

Stadel, O., 1936. Nahrungsuntersuchungen an Elbfischen. Zeitschrift für Fischerei und deren Hilfswissenschaften, Bd. xxxIv, pp. 45-6I.

Steven, G. A., I930. Bottom Fauna and the Food of Fishes. Fourn. Mar. Biol. Assoc. Vol. xvi, pp. 677-705.

— 1933. The Food Consumed by Shags and Cormorants around the Shores of Cornwall (England). Fourn. Mar. Biol. Assoc., Vol. xIX, pp. 277-92.

- 1938. Marine Biological Association of the United Kingdom. Report of the Council for 1937. Fourn. Mar. Biol. Assoc., Vol. xxiII, p. 264.

TAtTERSAll, W. M., I938. The Seasonal Occurrence of Mysids off Plymouth. Fourn. Mar. Biol. Assoc., Vol. xxiII, pp. 43-56.

Todd, R. A., I915. Report on the Food of Plaice. Bd. of Agric. and Fisheries, Fishery Investigations. II. Vol. II, 3, pp. I-3I.

von Buddenbrock, W., I936. What Physiological Problems are of Interest to the Marine Biologist in his Studies of the Most Important Species of Fish? Cons. Int. Expl. Mer., Rapp. Proc. Verb., Vol. cI.

Wailes, G. H., I935. Food of Clupea pallasii in Southern British Columbia Waters. Fourn. Biological Board of Canada, Vol. I, 6, pp. 477-86.

Walton, I., I659. The Compleat Angler. London.

Wheeler, J. F. G., I924. The Growth of the Egg in the Dab (Pleuronectes limanda). Quart. Fourn. Micr. Sci., Vol. Lxvin, pp. 64I-58.

Wilson, D. P., I936. The Development of Audouinia tentaculata (Montagu). Fourn. Mar. Biol. Assoc., Vol. xx, pp. 567-79. 